\title{
Procuring infrastructure for international sporting events: mapping the field for IPACS and beyond
}

Sue Arrowsmith, Ruth Bayley, Anna Gorczynska, Joshua Idoku, Steve Kay, Jorge Faria Lopes, Carlos Sebastian Barreto Cifuentes, Geo Quinot, Ke Ren, Ashraf-Ul-Bari Nobel, Astghik Solomanyan, Izabella Sobieraj, Gábor Soós and Alex Thurston ${ }^{1}$

\section{Introduction}

This article presents the results of a study of infrastructure procurement for international sporting events. The objective was to map both the institutional frameworks and the procedures and governance mechanisms. We were concerned only with the acquisition process and not with prior decisions on whether to host events, what to procure (such as the number and siting of stadiums) or subsequent maintenance ${ }^{2}$. The aim was to provide information relevant to studying the implementation of procurement objectives and the risks to attaining those objectives and to lay the foundations for further work. The study originated in work by the authors in collaboration with the OECD to assist the International Partnership Against Corruption in Sport (IPACS) ${ }^{3}$ in managing integrity risks, but also provides a map that can facilitate future study of other issues, such as sustainability.

The study sought to map procurement for key sport-specific infrastructure (such as stadiums and swimming pools) and a sample of other infrastructure (sport-specific, sport-related - such as athlete accommodation - and/or other infrastructure procured for the event (such as transport facilities) for 14 international events. It covered events of various sizes and types in the ten-year period to 2018, using public sources. These events were: Summer Olympic and Paralympic Games, London, United Kingdom, 2012 (London); Summer Olympic and Paralympic Games, Rio de Janeiro, Brazil, 2016 (Rio); Winter Olympic and Paralympic Games, Vancouver, Canada, 2010 (Vancouver); Winter Olympic and Paralympic Games, Sochi, Russia, 2014 (Sochi); World Games, Wrocław, Poland, 2017 (Wroclaw); Youth Olympics, Buenos Aires, Argentina, 2018 (Buenos Aires); Asian Games, Guangzhou, China, 2010 (Guangzhou); Commonwealth Games, New Delhi, India, 2010 (New Delhi); Central American and Caribbean Games, Veracruz, Mexico, 2014 (Vera Cruz); FIFA [soccer] World Cup, South Africa, 2010 (South Africa); Commonwealth Games, Gold Coast, Australia, 2018 (Gold Coast); FINA World Championships (aquatics), Budapest, Hungary, 2017 (Budapest); African Games, Brazzaville, Republic of the Congo, 2015 (Brazzaville); and Africa Cup of Nations (soccer), Gabon, 2017 (Gabon).

\footnotetext{
${ }^{1}$ Sue Arrowsmith, Achilles Professor of Public Procurement Law and Policy, School of Law, University of Nottingham; Ruth Bayley, Managing Director, Bayley \& Associates Pty Ltd; Anna Gorczynska, Professor, University of Lodz; Joshua Idoku; Steve Kay, consultant; Jorge Faria Lopes, PhD candidate, Universidade Católica Portuguesa; Carlos Sebastian Barreto Cifuentes, Research Assistant and PhD candidate, School of Law, University of Nottingham; Geo Quinot, Professor, Department of Public Law, Stellenbosch University; AshrafUl-Bari Nobel, Research Assistant and PhD candidate, School of Law, University of Nottingham; Ke Ren; Astghik Solomanyan, Research Assistant and PhD candidate, School of Law, University of Nottingham; Izabella Sobieraj, PhD Student, University of Lodz; Gábor Soós, PhD candidate, National University of Public Service, Hungary; and Alex Thurston, School of Sport, Exercise and Health Sciences, Loughborough University. The authors would like to thank Serban Filipon for his excellent assistance with technical work on this manuscript. ${ }^{2}$ All are controversial issues and perhaps more studied than our subject matter. As is well known, the value of funding these events and long term viability of the infrastructure, even when claimed to create a legacy, is often dubious. See e.g. J. Alm, World Stadium Index: Stadiums built for major sporting events - bright future or future burden? (Copenhagen: Danish Institute for Sports Studies/Play the Game, May 2012), available at https://www. playthegame.org/knowledge-bank/downloads/world-stadium-index/c714c866-7a44-4501-a9a5a3af00f4d750; S. Menary, "China's Programme of stadium diplomacy" (2015) 3:3 ICSS Journal 2; K. Schoonbee and S. Brümmer, "Public loss, FIFA's gain: How Cape Town got its 'white elephant'", in C. Schulz Herzenberg (ed.), Player and referee: Conflicting interests and the 2010 FIFA World Cup ${ }^{T M}$ (Pretoria: Institute of Security Studies, 2010), Ch.6, pp.133-167 [e-book], retrieved from http://ccs.ukzn.ac.za/files/ISS\%20Player\%20and\%20Referee.pdf.

3 See http://www.oecd.org/corruption/multi-stakeholder-sports-integrity-taskforces-established.htm.
} 
Study data from the first ten projects above was used as the basis for the 2019 IPACS report on procurement standards and risk management in procuring infrastructure for sporting events (IPACS report) ${ }^{4}$. That report analysed the aggregate data to identify and analyse integrity risks and make concrete proposals for mitigating them. This article supplements the IPACS report by giving more information on the methodology; providing data from four additional projects, which offer further evidence and insights; and presenting the key information through a project-based, as well as aggregate, approach, to place it in context.

We will, first, outline briefly the objectives and importance of the procurement process in this field, other research, and the objectives of IPACS (section 2). We then explain the aims and methodology of our mapping (section 3) and briefly summarise of IPACS' findings and recommendations based on our mapping of the ten initial events (section 4). Section 5 then presents a brief summary of the mapping findings in context for each of the 14 events. Section 6 concludes.

\section{Background and context}

As we will see, infrastructure procurement for international sporting events is almost entirely a public sector activity and objectives are largely the same as with public sector procurement in general ${ }^{5}$, notably value for money - delivery of what is required and on the best commercial terms - integrity, and sustainability. The means for achieving them is also largely the same, relying on a transaction-based approach with a competition for each transaction, as opposed to the partnering model found in much private sector procurement $^{6}$.

Such literature as exists highlights special features of "event" procurement, including the particular importance of achieving procurement objectives and the special challenges in doing so (see below). However, procurement for sport events - as with sport procurement generally - has attracted little interest as a distinct subject in management or legal literature ${ }^{7}$. Thus textbooks, including those on event management ${ }^{8}$ or sport law ${ }^{9}$ barely mention it and, while there is an increasing interest in, and research on, corruption and sport, this has not extended to procurement ${ }^{10}$. However, several works

\footnotetext{
${ }^{4}$ IPACS Task Force 1 Report, Mapping of procurement standards and risk management activities in the construction of infrastructure for sporting events (2019), p.53, citing the study as University of Nottingham and OECD (2018), "Collaborative research on procurement and risk management in infrastructure relating to sporting events for the purpose of IPACS Task Force" (unpublished).

5 See S. Arrowsmith, J. Linarelli and D. Wallace Jr., Regulating Public Procurement: National and International Perspectives (London: Kluwer Law International, 2000), Ch.1; S. Arrowsmith (ed.), Public Procurement Regulation: An Introduction (EU Asia Inter University Network for Teaching and Research in Public Procurement Regulation, 2011) available at

https://www.nottingham.ac.uk/pprg/documentsarchive/asialinkmaterials/publicprocurementregulationintroduct ion.pdf, Chs 1 and 2; S.L. Schooner, "Desiderata: Objectives for a System of Government Contract Law" (2002) 11 P.P.L.R. 103.

${ }^{6}$ See e.g. D. Parker and K. Hartley, "The Economics of Partnership Sourcing Versus Adversarial Competition: A Critique" (1997) 3 European Journal of Purchasing \& Supply Management 115.

${ }^{7}$ For a review see S. Arrowsmith, "Procurement and Sport Organizations", in T. Slack, T. Byers and A. Thurston (eds), Understanding Sport Organizations: the Application of Organization Theory 3rd edition, forthcoming (Champaign, IL: Human Kinetics), Ch.24. The lack of attention to corruption risks in procurement in international events is also highlighted in the IPACS report, p.5, which points out that most efforts on corruption in sport have primarily focused on general sports governance and competition manipulation.

${ }^{8}$ Books on event management only include a brief paragraph or so on procurement and related matters - e.g. M.M. Parent and S. Smith-Swan, Managing Major Sports Events: Theory and Practice (Abingdon: Routledge, 2013), p.63; D. Getz, Event Management \& Event Tourism, 2nd edn (New York: Cognizant Communication Corporation, 2005), p.118 - and discuss risk management in general terms without specific reference to procurement.

9 E.g. S. Gardiner, J. O'Leary, R. Welch, S. Boyes and U. Naidoo, Sports Law, 4th edn (London: Routledge, 2012); A. Lewis and J. Taylor, Sport: Law and Practice, 3rd edn (Haywards Heath: Bloomsbury, 2014); L.A. Sharp, A.M. Moorman and C.L. Claussen, Sport Law: A Managerial Approach, 3rd edn (London and New York: Routledge, 2017) - although this last does briefly discuss finance and ownership models.

${ }^{10}$ For example, G. Brooks, A. Aleem and M. Button, "The Extent of Fraud and Corruption in Sport" in G. Brooks, A. Aleem and M. Button, Fraud, Corruption and Sport (London: Palgrave MacMillan, 2013), Ch.3, pp.30-44: while the authors mention the area in a list of relevant topics, it is not covered in the case studies.
} 
do look at procurement from the perspective of one or more of the three objectives above in the context of "mega-events", notably the Olympics and FIFA World Cups ${ }^{11}$; and the United Nations Office on Drugs and Crime (UNODC) guide on corruption in mega-events gives procurement substantial attention ${ }^{12}$.

The funds involved in such events and their public importance and high visibility means that procurement failings can have significant adverse consequences. The extent and nature of such failings are amply illustrated by the mapping. For example, as we will see, of the 12 events in the study for which there was sufficient information for mapping, in seven the procurement gave rise to significant alleged or proven integrity issues (five were the subject of significant corruption findings or allegations (Sochi, Guangzhou, Rio, Veracruz and New Delhi), South Africa involved significant bid-rigging, and Budapest attracted criticism for waste and cronyism, while most were beset by extensive cost overruns beyond the norm for major infrastructure. Conversely, however, some of these same features of high spend and visibility also provide a positive opportunity to develop and showcase improvements or even excellence ${ }^{13}$, with potential benefits not just for future similar events but more broadly, as illustrated in the case studies of London, in which a procurement "legacy" (including for integrity) was an explicit objective, and Rio, which has arguably left a positive legacy in terms both of pursuing corruption and of modernising the procurement framework.

Literature on specific sporting events also indicates that these features of such events can present some specific challenges for procurement as catalogued by, for example, Schulz Herzenberg ${ }^{14}$, and these are again illustrated by our study.

One is that international sporting events are generally a "one-off". As IPACS points out ${ }^{15}$, this means that most host governments have no or limited experience in organising such an event. The one-off nature of the work can also make construction work more expensive, including because of large volumes of work on the market in a short timeframe and because of the absence of cost benchmarks. Bidders may also be deterred by the unique nature of the projects and/or high visibility, which create risks for contractors as well as procuring entities - a problem with the London Olympic stadium, as we will see.

Another significant problem is the immovable deadline: "when problems arise there can be no trade-off between schedule and cost, as is common for other megaprojects"16. This may help to explain why cost overruns for Olympic sport-related infrastructure greatly exceed those for other major construction projects ${ }^{17}$, as with three of the four Olympics in our study (London, Sochi, and Rio, Vancouver being the exception). It seems uncommon for event-specific infrastructure not to be completed in time: our mapped procurements produced just one example in the athletes' village for Veracruz

11 See the works cited in the event summaries below, in particular on London, South Africa and Rio.

12 United Nations Office on Drugs and Crime (UNODC), The United Nations Convention against Corruption: A Strategy for Safeguarding against Corruption in Major Public Events (United Nations, 2013), retrieved from http://www.unodc.org/documents/corruption/Publications/2013/13-84527_Ebook.pdf.

${ }^{13}$ As UNODC suggests, "The organization of a major event should serve as an opportunity to review and strengthen existing procurement, tendering and contracting rules" United Nations Office on Drugs and Crime (UNODC), The United Nations Convention against Corruption: A Strategy for Safeguarding against Corruption in Major Public Events (United Nations, 2013), p.34, at http://www.unodc.org/documents/corruption/Publications/2013/13-84527_Ebook.pdf.

${ }_{14} \mathrm{C}$. Schulz Herzenberg, "Introduction", in C. Schulz Herzenberg (ed.), Player and referee: Conflicting interests and the 2010 FIFA World Cup ${ }^{T M}$ (Pretoria: Institute of Security Studies, 2010), Ch.1, pp.1-19 [e-book], at http://ccs.ukzn.ac.za/files/ISS\%20Player\%20and\%20Referee.pdf.

${ }_{15}$ IPACS report, p.5.

${ }^{16}$ B. Flyvbjerg, A. Stewart and A. Budzier, "The Oxford Olympics Study 2016: Cost and Cost Overrun at the Games" (University of Oxford, Saïd Business School Research Papers, July 2016), p.14, available at https://eureka.sbs.ox.ac.uk/6195/1/2016-20.pdf.

17 B. Flyvbjerg, A. Stewart and A. Budzier, "The Oxford Olympics Study 2016: Cost and Cost Overrun at the Games" (University of Oxford, Saïd Business School Research Papers, July 2016), p.15, at https://eureka.sbs.ox.ac.uk/6195/1/2016-20.pdf. 
(although some appears not to have been completed to a satisfactory standard because of lack of time, as with the athletes' accommodation for Rio). Time pressures also make it difficult to control costs and prevent corruption, including because of pressure to modify regular procedures or to invoke exemptions - or can provide a pretext for dispensing with regular procedures even when not justified. Of the events in our study, New Delhi was seriously criticised by audit bodies for modifications to regular procedures and other problems caused by preparation delays, while Budapest was criticised by the media for exorbitantly expensive infrastructure against a backdrop of a "blanket" exemption from the usual requirements for open public tender (the stated justification for which, as discussed later, was that Budapest replaced another host just two years before the event). Time pressures can also make adequate control of amendments, with attendant corruption risks, more difficult.

Particular challenges also arise from the complexity of institutions involved, both in the local organising committees (LOCs) and more generally. Stakeholders often include public institutions, sometimes (as with several of our case studies) at multiple levels (local, regional and/or national), as well as national and international federations, sometimes with conflicting interests, as examined by Schulz Herzenberg et al in more detail in the context of one of our case study events, South Africa ${ }^{18}$. The structural challenges have sometimes been addressed by creating one or more bespoke agencies for organisation, including procurement, or at least new teams or units to deal with exceptional procurement demands, as with South Africa (see later). However, as the literature shows, a transient organizational structure also makes it more difficult to transmit lessons ${ }^{19}$ (something that the IOC has tried to address with the Olympic Games Knowledge Management Program). The bespoke nature of agencies can also contribute to the difficulty of ensuring transparency, as our study shows. Thus, as described below, where a specific bespoke agency is established for infrastructure procurement, accessing documentation can prove largely impossible once the agencies are wound up (London, Vancouver and Sochi), and this was also an issue with South Africa because of the winding up of both the main organising committee and units set up in existing Government departments. The involvement of multiple agencies can also create problems in this regard: at Rio where, as explained later, the central Transparency Portal in theory covered all contracts using federal funding, but the required information was simply not included by some agencies. Further challenges highlighted by Kauppi et $\mathrm{al}^{20}$ are short duration combined with a long planning period, massive size, diversity of activities and services, and the mix of employed and volunteer workforce.

Finally, the environment can involve high corruption risks, in particular the fact that the infrastructure procurement (as our study confirms) is overwhelmingly undertaken by the public sector combined with the increasing tendency for transparent and democratic Governments to eschew expensive events or fail in the bidding processes. Corruption and its causes are hard to measure ${ }^{21}$ and there may be a higher perception of corruption

\footnotetext{
${ }^{18}$ C. Schulz Herzenberg (ed.), Player and referee: Conflicting interests and the 2010 FIFA World Cup ${ }^{T M}$ (Pretoria: Institute of Security Studies, 2010) [e-book], at http://ccs.ukzn.ac.za/files/ISS\%20Player\%20and\%20Referee.pdf.

${ }^{19}$ R. Agarwal and W. Selen, "Dynamic Capability Building in Service Value Networks for Achieving Service Innovation" (2009) 40 Decision Sciences 431.

${ }^{20}$ K. Kauppi, C. Moxham and D. Bamford, "Should we try out for the major leagues? A call for research in sport operations management" (2013) 33 International Journal of Operations \& Production Management 1368, drawing on analysis of the Olympic Games by I. Minis, M. Parashi, and A. Tzimourtas, "The design of logistics operations for the Olympic Games" (2006) 36 International Journal of Physical Distribution \& Logistics Management 621, and on D.A. Beis, P. Loucopoulos, Y. Pyrgiotis, and K.G. Zografos, "PLATO helps Athens win gold: Olympic Games knowledge modelling for organizational change and resource management" (2006) 36 Interfaces 26.

${ }^{21}$ See generally A. Lanyi, "Measuring the Economic Impact of Corruption: A Survey" (Center for Institutional Reform and the Informal Sector at the University of Maryland - IRIS, The IRIS Discussion Papers on Institutions \& Development, Paper No. 04/04, February 2004), retrieved from http://unpan1.un.org/intradoc/groups/public/documents/apcity/unpan024055.pdf; and in the specific context of sport G. Brooks, A. Aleem and M. Button, "The Extent of Fraud and Corruption in Sport" in G. Brooks, A. Aleem and M. Button, Fraud, Corruption and Sport (London: Palgrave MacMillan, 2013), Ch.3, pp.30-44.
} 
in public sector activity simply because of greater scrutiny ${ }^{22}$ but there is also some indication of higher corruption levels ${ }^{23}$, possibly explained by factors such as low pay, pay structures, absence of a profit motive, bureaucratic rules, budgets unrelated to goals, and political involvement ${ }^{24}$. The last, in particular, can result in entrenched corruption, making it difficult to address by traditional transparency mechanisms which, as Trepte argues, assume a "principled principal" and that corruption is simply about controlling the rogue agent (procurement officer) ${ }^{25}$. Some of these features of the public sector are shared by sport federations involved in international events, which often lack even the basic oversight mechanisms found in the public sector ${ }^{26}$.

Although, as noted, procurement has received little attention in sport integrity literature, the risks it presents have led IPACS to focus on this. The globalisation of both sport and corruption that has led to greater integrity problems in sport as well as making them more difficult to address has led to various international cooperative efforts and IPACS, launched in $2017^{27}$, is one of these, with a core group of the International Olympic Committee (IOC), Council of Europe, OECD, United Nations Office on Drugs and Crime (UNODC) and UK Government. At its first working group meeting in June 2017 it set up three Task Forces ${ }^{28}$ : Task Force 1 on risks of corruption in procurement relating to events and infrastructure; Task Force 2 on integrity in selecting event hosts; and Task Force 3, concerned with compliance with good governance principles; and a further task Force, on cooperation between national criminal justice and law enforcement authorities and sport federations, was set up in July $2019^{29}$. The objective of Task Force $1^{30}$ is to improve the effectiveness and use of methodologies and tools for identifying and assessing risks - in particular, fraud and corruption risks ${ }^{31}$ - specific to procurement in sporting events and infrastructure projects; and to enhance strategies and action plans for managing these risks. To this end, IPACS envisaged an exercise for "the mapping of procurement standards to the specific context of sport" ${ }^{\prime \prime 2}$, which would be used to produce i) a tool for managing risks and ii) a pilot project for applying the results to a concrete case ${ }^{33}$. Our mapping exercise was carried out in part (the initial ten projects) in this context in collaboration with the OECD, with this part used as the basis for the IPACS report. ${ }^{34}$ The IPACS report summarises the results of the mapping and, based on

\footnotetext{
${ }^{22}$ F. Jenny, "Competition and Anti-corruption Considerations in Public Procurement", in Organisation for Economic Co-operation and Development (OECD), Fighting Corruption and Promoting Integrity in Public Procurement (Paris: OECD Publishing, 2005), Ch.3, pp.29-35, available via https://www.oecdilibrary.org/governance/fighting-corruption-and-promoting-integrity-in-public-procurement_9789264014008en.

${ }^{23}$ E.g. Organisation for Economic Co-operation and Development (OECD), "2014 OECD Survey on Managing Conflict of Interest in the Executive Branch and Whistleblower Protection" (OECD, 2014), retrieved from http://www.oecd.org/gov/ethics/2014-survey-managing-conflict-of-interest.pdf.

${ }^{24}$ S. Rose-Ackerman and B.J. Palifka, Corruption and Government: Causes, Consequences, and Reform, 2nd edn (Cambridge: Cambridge University Press, 2016).

${ }^{25}$ P. Trepte, "Corruption and Procurement: Recalibrating the Sights", in A. La Chimia and P. Trepte (eds), Public Procurement and Aid Effectiveness: a Roadmap under Construction (Oxford: Hart Publishing, 2019), Ch.7, pp.137-171.

${ }_{26}$ Organisation for Economic Co-operation and Development (OECD), "Organising Sporting Events: Preventing corruption and promoting responsible business conduct" (OECD, May 2016), available at http://www.oecd.org/corruption/Corruption-Responsible-Business-Conduct-Large-Sporting-Events.pdf. 27 Initially called the International Sports Integrity Partnership, and launched in February 2017 at the International Forum on Sport Integrity of the International Olympic Committee: (IOC) https://www.olympic.org/news/international-forum-for-sports-integrity-steps-up-action-to-preventcompetition-manipulation-and-corruption-in-sport.

${ }^{28}$ https://www.coe.int/en/web/sport/newsroom/-/asset_publisher/x9nLQ8ukPUk9/content/council-of-europehosts-first-meeting-of-international-partnership-against-corruption-in-sport. For the Task Force terms of reference see: http://www.oecd.org/corruption/multi-stakeholder-sports-integrity-taskforces-established.htm.

${ }^{29}$ See https://www.sportsintegrityinitiative.com/ipacs-steps-up-cooperation-between-criminal-justiceauthorities-and-sports-organisations/.

${ }^{30}$ The terms of reference are at: https://rm.coe.int/terms-of-reference-of-task-force-1-of-the-internationalpartnership-ag/16807b6c84.

${ }^{31}$ The terms of reference, para.5, refer specifically to fraud and corruption but para.6 refers to bid rigging also.

32 Para.9 of the terms of reference.

${ }^{33}$ Para. 6 of the terms of reference.

${ }^{34}$ IPACS report, p.32.
} 
this, draws some conclusions on integrity risks and how to mitigate them, along with practical recommendations that include a checklist for future events (which will be piloted at an actual event to be selected shortly by the Taskforce). As described below, our study also includes four further projects. As noted, we do not seek here to replicate in detail the analysis and conclusions of the IPACS report but just to highlight its key points; offer some additional perspectives based on our further work; and then present the results of the mapping in a more contextual manner, through an event-by-event summary.

\section{Methodology}

As mentioned, our study covered the institutions and procedures for the procurement of infrastructure for 14 events by reference to certain standards for mitigating risks (particularly integrity risks) in infrastructure projects. The initial work was done in collaboration with the OECD, the technical lead for IPACS Task Force 1. The methodology was initially devised by IPACS, led by the OCED, and filled out and refined by some of the current authors. The authors conducted the actual mapping, covering an initial ten events (chosen by IPACS) and a further four.

Procurements were selected for analysis at three levels: the event level, the infrastructure level, and the procurement level.

As to the event level, events were chosen from those in 2009-2018, to make the information current. The choice was made from an initial long list of 44 identified by the authors as involving major infrastructure work, which listed simply (where available) the procuring entities and the infrastructure, divided into sport-specific (pools, stadiums etc) and other infrastructure (such as, transport infrastructure and athlete villages), and the cost of each piece. This long list now provides a bank of information for further projects (such as a study of social and environmental dimensions). Events for the long list were identified with a view to providing a varied, although not necessarily representative, sample, based on criteria relating to "type of infrastructure, geographical balance and event size $\mathrm{e}^{\prime 35}$ and the nature of the event in terms of single-sport /multi-sport, and global/non-global (the latter including regional events, the Commonwealth Games and single-country events). IPACS then selected ten events for further study. Four more were added to our own study to broaden both the geographic scope and the variety, in particular by including one from the Antipodes, and including additional and single-sport events in both Europe and Africa to broaden coverage on these continents and extend coverage of single-sport events.

The sample of 14 was influenced by IPACS' decision to select the initial ten only from those events - 44 out of 48 initially identified as falling with the IPACS criteria - for which a minimum amount information referred to above (entity, nature of infrastructure and cost) was publicly available. This limited, in particular, study of events in the Middle East and Africa. However, as a result of the decision to cover more events from Africa and further single sport events, our sample of 14 included two events, Brazzaville and Gabon, for which this longlisting information was not available. Only one event was included from North America; although the criteria warranted including more, no event involving significant infrastructure procurement could be identified for the ten-year period covered.

At the infrastructure level, it was considered unnecessary for a significant sample, and disproportionate given the IPACS project timescales, to map all infrastructure procurement for each event. Mapping was therefore done for each event as follows. First, where possible, the mapping included the most important sport-specific infrastructure in terms of value and significance, such as the main stadium and aquatics centres for multi-sport events. Secondly, it sought to cover a range of other sport-

${ }^{35}$ IPACS report, p.9. 
specific infrastructure, covering a variety from different categories (broken down into outdoor arenas, indoor arenas (including courts, velodromes etc), ski facilities, bobsleigh/luge tracks, golf courses, bike lanes/trails, water sport or other open water facilities, and mixed facilities. For most events it was possible both to identify all the infrastructure and find a reasonable amount of information. Therefore the mapping covered all or substantially all of this infrastructure for smaller events ${ }^{36}$ and the main venues plus some smaller venues for the two summer Olympics (Rio - where $50 \%$ by value was mapped - and London), for the Gold Coast, and for New Delhi ( $20 \%$ by value being mapped in the latter case), as described later. For both New Delhi and Rio the choice of smaller items was influenced to some degree by availability of information, and more smaller items were mapped for Rio than London because of the greater ease with which the theoretically available information could be accessed. As explained later, information was not, however, so readily available for six events: South Africa, Sochi, the Guangzhou, the Vancouver, the Brazzaville and Gabon. In the first three cases there was sufficient information to map some procurements (although in the case of Sochi not relating to the sport venues); in these three cases the selection was made, however, in large part based simply on the fact that information was available. With the last two there was almost no information so that no mapping was possible at all. For some events mapping also covered, thirdly, other infrastructure ${ }^{37}$, either sport-related (such as athlete villages) or other, such as transportation. As noted, with Sochi all mapped infrastructure fell into this category as there was little information on other infrastructure. For some events, the choice was made specifically to give an overall picture, but for others, in particular, Sochi, Vancouver, Guanghzhou and New Delhi, was influenced more by the information available.

At the procurement level, a particular piece of infrastructure could involve just one procurement (frequently the case) or multiple procurements. In the latter case, to the extent possible, all procurements were analysed for each piece. Some procurements were organised to cover parts of more than one piece of infrastructure (for example, track laying at New Delhi) and, where these were included in the mapping, have been categorise listed in Table 1 below as separate pieces since they do not relate to any one specific infrastructure piece.

Altogether, the mapping covered 54 pieces of infrastructure and 97 procurements across 12 events (none being formally mapped for Brazzaville and Gabon, given the absence of information), of which 42 pieces of infrastructure and 76 procurements were taken into account by IPACS ${ }^{38}$, the others (12 pieces of infrastructure involving 21 procurements) relating to two additional events mapped for our own study (Gold Coast and Budapest). Table 1 below lists the events and the infrastructure mapped, plus the main sporting infrastructure (three pieces) procured for Brazzaville and Gabon.

\section{[In-house editor: insert Table 1 here. Sent for revision v8 14.08.19]}

In considering the results of the mapping, the extent to which the sample was influenced by availability of information must be kept in mind, including the fact that the IPACS sample omitted the most opaque procurements. As explained later, it transpired that the infrastructure for two of the four further events in our own study was financed by China, a common approach with international sporting events/infrastructure in Africa (indeed,

\footnotetext{
${ }^{36}$ Budapest, Vera Cruz, Wroclaw and Buenos Aires.

${ }^{37}$ Listed under the headings of accommodation; media centres and catering facilities; site preparation, landscaping and utilities; transportation infrastructure; and operation/training infrastructure (for example, for event medical services).

38 IPACS report, p.10, Table 1.2. We have omitted from the figure on number of pieces of infrastructure studied the contract for the delivery partner for the London 2012 Olympics, which is listed as infrastructure in Table 1.2 of the IPACS report, since this only involved services relating to the infrastructure procurement, and contracts involving services only (e.g. design services, or auditing services relating to the infrastructure) were not otherwise mapped.
} 
the dominant approach in larger events) and also found in other developing countries ${ }^{39}$, often involving the whole infrastructure project being implemented by China under rules laid down by the Chinese Government ${ }^{40}$. Clearly this phenomenon needs to be considered when looking at the overall picture of sporting infrastructure. As noted, availability of information also influenced selection at infrastructure and procurement level, so that use of public tenders overall may not be as great as it appears (see the later discussion); but the impact of selectivity within many of the events is in fact likely to be limited at least for the venue infrastructure, given the overall volume and nature of coverage.

The study examined the application in procuring the mapped infrastructure of certain procedural and institutional features relevant for achieving procurement objectives in a public sector environment. IPACS work, as we have seen, focused specifically on integrity risks, covering corruption (including bribery), fraud and bid rigging ${ }^{41}$ - concepts which overlap (for example, where a public official is bribed to ignore bid rigging) but are distinct. Thus, the study focused on matters relevant to mitigating those risks. It did not attempt any comprehensive evaluation of actual integrity and the relationship of the mapped features to integrity outcomes. However, it did collate such information as was in the public domain on integrity outcomes, to provide context and to lay the foundations for further study.

While the study focused on integrity there is, of course, an important relationship between integrity and other procurement objectives, including value for money, in that failing to achieve the former can compromise the latter - for example, where bid rigging leads to above-market prices or bribery results in a more expensive or incompetent contractor $^{42}$. In addition, many tools employed in the public sector to achieve integrity, notably transparency, a transaction-based approach and competition through formal tendering, are also seen as a means to achieve other objectives, including value for money, effective implementation of social and environmental policies, open markets, equal treatment as a substantive value, and accountability ${ }^{43}$. Thus the information collected may be relevant also to risks to other objectives. There is, as is well known, tension between integrity and value for money (and also social and environmental objectives), in that approaches used to mitigate integrity risks can sometimes hinder such objectives $^{44}$ - for example, where limits on discretion preclude negotiation that could produce better prices or service design ${ }^{45}$. However, the information obtained in the study was quite high-level information on matters - such as use of open public tendering ${ }^{46}$ - that are accepted in international standards as central to public

\footnotetext{
${ }^{39}$ See e.g. J. Alm, World Stadium Index: Stadiums built for major sporting events - bright future or future burden? (Copenhagen: Danish Institute for Sports Studies/Play the Game, May 2012), at https://www.playthegame.org/knowledge-bank/downloads/world-stadium-index/c714c866-7a44-4501-a9a5a3af00f4d750; S. Menary, "China's Programme of stadium diplomacy" (2015) 3:3 ICSS Journal 2. We found no other evidence of donor funding of the events in our study, although it should be noted that the study looked only at procurement rules and not financing (although a study of the budgetary information for the 2010 South Africa World Cup confirmed that no donor funding was involved).

${ }^{40}$ E.g. S. Menary, "China's Programme of stadium diplomacy" (2015) 3:3 ICSS Journal 2.

41 These concepts have slightly fuzzy boundaries but their core is well understood and clear.

${ }^{42}$ See e.g. S. Rose-Ackerman and B.J. Palifka, Corruption and Government: Causes, Consequences, and Reform, 2nd edn (Cambridge: Cambridge University Press, 2016).

${ }^{43}$ S. Arrowsmith (ed.), Public Procurement Regulation: An Introduction (EU Asia Inter University Network for Teaching and Research in Public Procurement Regulation, 2011) available at https://www.nottingham.ac.uk/pprg/documentsarchive/asialinkmaterials/publicprocurementregulationintroduct ion.pdf.

${ }^{44}$ E.g. S. Kelman, Procurement and Public Management: The Fear of Discretion and the Quality of Government Performance (Washington, DC: The AEI Press, 1990); F. Anechiarico and J.B. Jacobs, The Pursuit of Absolute Integrity: How Corruption Control Makes Government Ineffective (Chicago, Illinois: University of Chicago Press, 1996).

${ }^{45}$ See, for example, K. Krueger, "The Scope for Post-tender Negotiations in International Tendering Procedures", in S. Arrowsmith and A. Davies (eds), Public Procurement: Global Revolution (London: Kluwer Law International, 1999), Ch.10.

${ }^{46}$ Such as the UNCITRAL Model Law on Public Procurement 2011 (Model Law) (at https://www.uncitral.org/pdf/english/texts/procurem/ml-procurement-2011/2011-Model-Law-on-Public-
} 
procurement systems, and broadly regarded as relevant to various objectives. The information collected also provides useful foundations for collecting additional information for further studies - for example, on sustainability.

The analysis was based on information in the public domain, either directly or on request (including through use of freedom of information laws). A key source was publicly available (generally on-line) documentation generated by the procurement procedure itself, such as solicitations, tender documentation, and award notices. The study also used other public information, such as government audit reports, the limited academic literature, other literature (such as that of international organisations) and media. Searches were conducted in all main relevant languages (for example, in the case of Chinese-financed procurement in Africa, in Chinese, English and French). Within the samples, both obligations to publish and actual publication (including compliance with publication obligations) varied, as did retention of published information after the event. These points and their significance for integrity risks are briefly considered later. IPACS initially intended the public information to be supplemented by information from questionnaires by IPACS, in particular to explore information and risk management strategies and integration of procurement capacity with other event activity ${ }^{47}$, but was able to collect this information only for Buenos Aires (perhaps because the event was still ongoing).

For each procurement information was sought on a range of matters considered most relevant to integrity risks, using a public sector framework, and based (as envisaged in the terms of reference of IPACS Task Force $1^{48}$ ) on existing international efforts and standards ${ }^{49}$. It needs to be stressed that these reflect the approach to integrity within a public sector framework since, as mentioned, the commercial sector's approach is often quite different ${ }^{50}$. IPACs' approach assumed that infrastructure procurement for international sporting events is generally undertaken by the public sector, an assumption verified in the study, as explained later. Collecting information that was comparable across different procurements required a carefully nuanced framework, as legal concepts with similar names may be quite different (see, for example, the section on regulatory frameworks below).

\section{Outline of the map}

\subsection{Introduction}

In this section we briefly present the key features of our map, along with key findings and recommendations from the IPACS report that were informed by the map of ten of our events. The points made are in general based solely on the mapped procurements but, where specified, also refer to contextual information from other sources.

\subsection{Public availability of information}

As mentioned, our map needs to be considered in the light of the influence of availability of information on the sample. Thus, as noted, the IPACS study covers only events for

Procurement-e.pdf); the WTO Agreement on Government Procurement 2012 (GPA 2012) (at https://www.wto.org/english/docs_e/legal_e/rev-gpr-94_01_e.htm); and the EU procurement directives (which are discussed later).

47 IPACS report, p.1.

${ }^{48}$ Paras 7 and 8 of the terms of reference.

49 Such as the OECD "Recommendation of the Council on Public Procurement" (OECD, 2015) (at https://legalinstruments.oecd.org/en/instruments/OECD-LEGAL-0411); "Recommendation of the OECD Council on Fighting Bid Rigging in Public Procurement" (OECD, 2012) (at

https://www.oecd.org/competition/oecdrecommendationonfightingbidrigginginpublicprocurement.htm); and "OECD Recommendation on Public Integrity" (OECD, 2017) (at http://www.oecd.org/gov/ethics/OECDRecommendation-Public-Integrity.pdf). As noted earlier, the information sought in the context of award procedures reflects also the standards in various international instruments.

50 D. Parker and K. Hartley, "The Economics of Partnership Sourcing Versus Adversarial Competition: A Critique" (1997) 3 European Journal of Purchasing \& Supply Management 115. 
which basic information was publicly available, although our own study also includes two for which this was not the case; and of the 12 events mapped for this article the procurements studied for, in particular, Sochi, Guangzhou and Vancouver was determined mainly by availability of information. For most of those 12 events, as we will see in the summaries, information on some matters, notably risk management and internal controls and audit, was sparse or non-existent. However, there was generally significant information on the award procedure. The reasons for this, in particular, whether because the latter phase has a more direct impact on suppliers and therefore is often subject to greater visibility requirements for their benefit, or because there that phase involves better attention to risks and therefore there is more to find, are not clear.

Since availability of information is itself a mechanism for mitigating integrity risks, relevant to various dimensions of transparency in public procurement (publicity for opportunities, disclosure of the rules of the process and monitoring and enforcement $)^{51}$, the availability (or otherwise) of public information is itself a potentially important finding. However, the event summaries show that absence of public information at the time the study does not necessarily indicate a lack of transparency giving rise to integrity risks (although it limits potential for uncovering issues later): for example, for some events (such as Guangzhou and South Africa) absence of information might possibly be explained by the limited use of electronic means at the time, while for others information that was clearly public at one time may simply not remain in the public domain, as with Vancouver, Sochi and the Gold Coast.

\subsection{The procuring entity/entities}

Although, as seen in the event summaries, the nature and number of the procuring entities varied greatly, our mapping confirmed that procurement of infrastructure (both venues and other) for international sporting events tends to be undertaken by public sector bodies, subject to public procurement frameworks. This was the case with nearly all the mapped procurement, as well as for nearly all other infrastructure procurement undertaken for the study events on which information was available (although, as we will see, the venue procurement for Sochi was carried out by the State Corporation for the Construction of Olympic Venues and the development of the city of Sochi (OlymStroy) set up for the Games, which as a state corporation was subject only to a skeletal procurement regime). Only in very limited cases was infrastructure procurement undertaken by entities not subject to public procurement frameworks ${ }^{52}$.

As the event summaries show, for the most part the public bodies undertaking this work were established institutions with a remit over the activity at federal, state/provincial or municipal level - for example, general authorities, authorities invested with responsibility for public works, or specialist agencies concerned with, for example, transport. Frequently, this meant more than one procuring entity, especially where the infrastructure was geographically dispersed and/or when more than one level of government was involved. For example ${ }^{53}$, major procurements for Rio were undertaken by RioUrbe - Municipal Company for Urban Development, the Municipality of Rio de Janeiro and the state government; for South Africa infrastructure procurement (stadiums and roads) was undertaken by nine host cities as well as numerous specialist agencies, such as national and regional transport agencies; and at New Delhi at least seven entities were involved in major infrastructure procurement for sporting venues alone. We

\footnotetext{
${ }^{51}$ S. Arrowsmith, J. Linarelli and D. Wallace Jr., Regulating Public Procurement: National and International Perspectives (London: Kluwer Law International, 2000), pp.73-75.

${ }^{52}$ Examples from the case studies include the athletes' village for the Sochi, carried out by a limited liability company not subject to public procurement law; some construction works to finalise venues and install spectator facilities for the London 2012 Olympics, undertaken by the London Organising Committee of the Olympic and Paralympic Games (LOCOG), a private company not considered subject to public procurement law (which was also responsible for most of the Games supplies and services procurement); and work on upgrading a tennis stadium undertaken by the All India Tennis Association with finance from a government grant.

53 See the event summaries.
} 
noted earlier difficulties created by involvement of multiple agencies and our study provides illustrations, such as the difficulty of ensuring that all federally-funded procurement for Rio was actually included in the central database.

For some events, a specialist agency was set up either for managing or procuring infrastructure, or with responsibilities in this area: this was a popular, although not universal, model for mega-events. As the event summaries explain, a special body that undertook at least some venue infrastructure procurement ${ }^{54}$ was set up in four of the 12 mapped events, Sochi, London, Vancouver, and Budapest (although in the last case some of the large infrastructure contracts were also undertaken by existing bodies), all as public bodies (semi-public in the case of Sochi). The information available on these dedicated agencies highlights the possibilities offered for successful and innovative approaches provided by a "blank canvas", as shown at London (see the event summary), but also the fact that bespoke agencies may not leave significant records once wound up. The latter contributes to the danger highlighted in literature that a transient organizational structure can make transmission of lessons more difficult ${ }^{55}$; while significant efforts were made in London to counteract this by producing a legacy website $^{56}$ this, of course, produces a version of events edited by the actors.

\subsection{The regulatory frameworks}

Public procurement procedures are in most jurisdictions governed by detailed, and often enforceable, national legal rules ${ }^{57}$, although in some the framework is based on wholly or in part on administrative guidance or instructions. In general, applicable legal frameworks have tended to converge, being increasingly based on international instruments, such as the UNCITRAL Model Law on Public Procurement $2011^{58}$ (Model Law), World Trade Organisation Agreement on Government Procurement (GPA) ${ }^{59}$ or, in Europe, the GPA-compatible EU procurement directives ${ }^{60}$, although significant differences remain; and different rules also frequently apply at national, regional and local level, or between bodies at the same level. The regulatory picture may also be complicated where a project is aid-funded, when the procurement may be subject to donor rules or even

\footnotetext{
${ }^{54}$ At Wroclaw a bespoke body did most of the non-construction procurement, a model also found with some other events, including the London 2012 Olympics: see the event summaries below.

${ }^{55}$ R. Agarwal and W. Selen, "Dynamic Capability Building in Service Value Networks for Achieving Service Innovation" (2009) 40 Decision Sciences 431.

${ }^{56}$ https://webarchive.nationalarchives.gov.uk/20180426101359/http://learninglegacy.independent.gov.uk/.

57 On the legal regulation of public procurement in general, including the role of international instruments, see

S. Arrowsmith, J. Linarelli and D. Wallace Jr., Regulating Public Procurement: National and International Perspectives (London: Kluwer Law International, 2000), Ch.1; S. Arrowsmith (ed.), Public Procurement Regulation: An Introduction (EU Asia Inter University Network for Teaching and Research in Public Procurement Regulation, 2011) at

https://www.nottingham.ac.uk/pprg/documentsarchive/asialinkmaterials/publicprocurementregulationintroduct ion.pdf; P. Trepte, Regulating Procurement: Understanding the Ends and Means of Public Procurement Regulation (Oxford: Oxford University Press, 2004).

${ }^{58}$ Currently the UNCITRAL website notes that this text is used for benchmarking public procurement reforms by African Development Bank, Asian Development Bank, European Bank for Reconstruction and Development, Inter-American Development Bank, OECD and the World Bank and lists 25 countries as having "used" the Model Law and its accompanying Guide to Enactment as the basis for their procurement reforms: http://www.uncitral.org/uncitral/en/uncitral_texts/procurement_infrastructure/2011Model_status.html. However, anecdotal evidence and other sources indicate that the number is much higher e.g. on its influence in Anglophone Africa see generally G. Quinot and S. Arrowsmith (eds), Public Procurement Regulation in Africa (Cambridge: Cambridge University Press, 2013).

59 R.D. Anderson and A.C. Müller "The Revised WTO Agreement on Government Procurement (GPA): Key Design Features and Significance for Global Trade and Development" (2017) 48 Georgetown Journal of International Law 949; R.D. Anderson and N. Sporysheva, "The revised WTO Agreement on Government Procurement: evolving global footprint, economic impact and policy significance" (2019) 28 P.P.L.R. 71.

${ }^{60}$ The most significant of which is Directive 2014/24/EU of the European Parliament and of the Council of 26 February 2014 on public procurement and repealing Directive 2004/18/EC [2014] O] L 94/65 (Public Contracts Directive). On the EU directives see S. Arrowsmith, The Law of Public and Utilities Procurement: Regulation in the EU and UK, 3rd edn (London: Sweet \& Maxwell, Volume 1 2014, Volume 2 2018).
} 
carried out directly by the donor ${ }^{61}$. It is assumed a regulatory framework following the core elements of international models - such as open solicitations and supplier review procedures - has a role in limiting integrity risks, although - as we noted earlier - its exact contribution, in particular in countries with endemic integrity problems is open to debate. The study therefore sought information on both the regulatory frameworks and the extent to which certain steps envisaged by international models were applied.

In the 12 mapped events, the mapped procurement was undertaken by the host nation using national rules (with no evidence found of donor funding), involving to some degree, and in most cases a very significant degree, of regulation, although for the Gold Coast and to some extent Delhi the framework was non-legal. (On the other hand, the stadium procurements for Brazzaville and Gabon which, as noted, were funded by China may have been done by the Chinese authorities using their own rules, as is common for Chinese-funded sport facilities in Africa ${ }^{62}$, or by the national authorities under a framework set by China ${ }^{63}$; there was no public information available, however, to verify the position.) In some of the 12 mapped events, different regimes applied to different levels of government and/or localities (for example, New Delhi and South Africa), and/or some was quite skeletal (as we explained was the case for Sochi).

As noted, the special challenges of procuring infrastructure for sporting events, including immoveable timescales, can create special problems in applying the regulatory framework. These can lead to pressure to modify the usual rules or to use urgencybased exemptions, whether for good reason, because of avoidable problems, or because modifications or exemptions are exploited for illegitimate motives, in all cases creating risks for procurement objectives. Some of these points are illustrated in the sample events. Thus, as discussed later, New Delhi involved many "urgent" non-competitive awards justified by reference to urgency because of poor planning - something generally precluded by international models, however, ${ }^{64}$, in view of the risks created by allowing exemptions based on entities' own dilatory conduct ${ }^{65}$; while a special Law exempted much of the procurement for Budapest from the usual procurement laws ${ }^{66}$.

Our sample also illustrates, however, that the same factors of high visibility and high spend that create special risks, also give rise to special opportunities for improvement, including of the legal framework. Our sample events included one legal initiative of this kind, the Differentiated Contracting Regime (Law No. 12462/2011) in Brazil, as discussed in the event summary.

\subsection{Use of electronic procurement and communications}

\footnotetext{
${ }^{61}$ A. La Chimia, "Donors' influence on developing countries' procurement systems, rules and markets: a critical analysis", in S. Arrowsmith and G. Quinot (eds), Public Procurement Regulation in Africa (Cambridge: Cambridge University Press), Ch.11, pp.219-260 at pp.235-238.

62 S. Menary, "China's Programme of stadium diplomacy" (2015) 3:3 ICSS Journal 2.

${ }^{63}$ On applicable procedures at the present time see Measures on the Management of Turnkey Foreign Technical Assistance Projects (Draft) (No. 3 MOFCOM Circular, 2015) and the Measures on the Management of Foreign Technical Assistance Projects Management (Draft) (No. 5 MOFCOM Circular, 2015), which came into effect on 1.8.2016.

${ }^{64}$ GPA 2012, art.XIII(1)(d), allowing direct awards only "insofar as is strictly necessary where, for reasons of extreme urgency brought about by events unforeseeable by the procuring entity" the subject matter cannot be obtained through an open public tender in our sense; and, in the EU, e.g. Public Contracts Directive; with similar wording art.32(2)(c), which also states that "The circumstances invoked to justify extreme urgency shall not in any event be attributable to the contracting authority". These instruments also provide for very short time period for open public tenders to deal with such cases of urgency: e.g. GPA 2012, art. XI(2) and (4); Public Contracts Directive, art.27(3) and art.28(6). The UNCITRAL Model Law on Public Procurement 2011 is even stricter, providing (in art.30(4)(a) and (b)) only for a flexible form of competition ("competitive negotiations") in cases of urgency (which is again confined to where the entity is not at fault, except where there is a catastrophe), rather than direct awards (although direct awards are allowed in cases of catastrophe: art.30(5)(b)).

65 See the event summary for Delhi.

66 See the event summary for Budapest.
} 
Use of electronic means has the potential to reduce integrity risks and otherwise to enhance performance in many ways, and as Hayman's article in this issue of the Review explains $^{67}$, open contracting using such means has significant potential in this respect. However, use of electronic means in many events was quite limited for many of our events, being confined largely to publishing the solicitation - in most cases (usually, although not always, required by law) - and award notices, although in several cases other documentation is, or was, available on line (such with Rio, Buenos Aires and the Gold Coast). Even when significant efforts were made to put documentation on line, however, as at Rio, information was often incomplete ${ }^{68}$ (possibly because of the difficulty of securing compliance by multiple agencies). However, as IPACS notes, the events took place in a period which saw a gradual spread of e-procurement system worldwide and "As such, it is understandable that e-governance tools in general, and e-Procurement systems in particular, were not used....." ${ }^{69}$ This is an area in which significant developments, including in open contracting, could have an impact on future events, as Hayman discusses. It is also worth reiterating that even to the extent that electronic processes were involved records were not always retained or accessible (see the summaries of London, Sochi and the Gold Coast) ${ }^{70}$ and improvements here could facilitate scrutiny for problems, further study of the issues, and transmission of lessons learned.

\subsection{Nature and design of the procurement}

The study also looked at the nature and design of procurements, including the approach to lots (within a single procurement or through multiple procurements); the approach to delivery in terms of packaging of the design, build, operation and ownership elements, and the payment models, including use of private finance. The IPACS report analyses the respective advantages and disadvantages of different approaches in these respects, drawing on the literature, and summarises the findings on the approach of the ten events in the study ${ }^{71}$.

Another notable finding was that design and build was generally used. However, as the event summaries show, in several cases, an outline design was commissioned separately: for example, the London Aquatics Centre illustrates a successful use of this approach (although the initial design was novated to the building contractor) ${ }^{72}$. Secondly, the sport-related infrastructure was overwhelmingly built with public funds and taken into or retained in public ownership, this being the case for all sport venues mapped. The Central American Village (athletes' accommodation) for the 2014 Veracruz Central American and Caribbean Games was the only example of use of private finance and ownership for sport-related infrastructure - somewhat unsuccessful, since the Village was not ready for the Games ${ }^{73}$.

\subsection{Planning phase}

As IPACS notes: "The early stages of the procurement cycle consisting of project design, budget estimates and understanding of market capabilities are of key importance, as shortcomings in these early phases may open doors for wrongdoings later on in the delivery cycle."174 As presented there, based on the data from 75 construction procurements for 43 pieces of infrastructure in ten events, there was little public evidence of such activity. For example, there was evidence of a feasibility study for about half of projects; evidence of a cost-benefit impact of delivery method for only two;

\footnotetext{
67 G. Hayman, "Better procurement for major sporting events: will we see open contracting for Paris 2024?" (2019) 28 P.P.L.R. xxx.

68 See the event summary for Rio.

${ }^{69}$ IPACS report, p.29.

70 See the relevant event summaries below.

${ }^{71}$ IPACS report, pp.22-25.

72 See the event summary for London below.

${ }^{73}$ See the event summary for Veracruz.

74 IPACS report, p.21.
} 
and evidence of market analysis for none ${ }^{75}$. However, it is difficult to draw conclusions given that publication of such documents is often neither legally required nor inherent in the document's function, although IPACS does suggest the evidence supports the conclusion that pre-tendering transparency measures were not "systematically implemented"76. In the case of advance publication of notice of opportunities, an inherently public activity, there was evidence of this for $27 \%$ of the above procurements ${ }^{77}$.

\subsection{Risk management activities}

As IPACS noted, "There is limited evidence that implementing agencies took a strategic approach to risk management in the events reviewed; however, ad hoc activities to assess risks in some events were identified. Specifically, only three of the ten events had readily available information on the implementing agency's governance documents that demonstrated risk management objectives, policies or activities" (London, South Africa and New Delhi). However, absence of public documentation does not necessarily mean that such a strategic approach did not exist: as explained below in our event summary of the Gold Coast, documents relating to risk management are not routinely published in the jurisdiction concerned (Queensland, Australia) but risk management is systematically undertaken. Six of the ten IPACS events were also shown to have conducted risk assessments related to specific procurements or project implementation, but such activities could have existed for other events, too. As explained later, London is of particular interest because of its systematic, and apparently quite successful, approach to integrity risks although, importantly, in a country in which corruption is not endemic.

As IPACS highlights ${ }^{78}$, "Periodic integrity risk assessments-incorporated into broader risk assessments or as a stand-alone exercise-are critical to taking a strategic approach to risk management in infrastructure delivery" and this approach is advocated in the OECD's Recommendation on Public Integrity as well as in various international standards for internal control and risk management. More generally, given the specific features of organisation of sporting events highlighted, the report concludes that "To effectively safeguard integrity related to sporting events, a critical early step is to have a dedicated entity that leads, oversees and co-ordinates risk management activities with multiple stakeholders." 79

The study sought also specific information on audit and inspection activities. Six of the twelve events reviewed in detail were shown to have had both internal and external audit or inspection; five showed evidence just of external audit ${ }^{80}$, although the audit reports themselves were found only for three events; and no evidence of audit was uncovered for Budapest ${ }^{81}$. Again, however, absence of evidence does not allow the conclusion that no such activity existed. Based on some of the events studied, and referring specifically to South Africa and London, IPACS also highlights that improving risk management and detection activities in international events can act as a catalyst for more general improvement ${ }^{82}$, including through clarification of responsibilities of implementing parties (who bears primary responsibility for this under accepted standards) and external audits and other mechanisms. Improvement of integrity mechanisms is an important legacy also of Brazil's experience with Rio, as discussed in the event summary. Given the limited information in the public domain about risk

\footnotetext{
75 IPACS report, p.22.

${ }^{76}$ IPACS report, p.26.

77 For the additional two projects covered by our own study in detail, such notices were found for all the procurement studied in relation to the Gold Coast, but none of those studied for Budapest.

78 IPACS report, p.34.

${ }^{79}$ IPACS report, p.35.

80 This does not mean that no other audit existed, merely that it was not publicly evidenced.

${ }^{81}$ Although again this does not necessarily mean that none existed.

82 IPACS report, pp.35-36.
} 
management, it certainly seems desirable to improve access to such information, at the least to facilitate further study and the transmission of lessons for future events.

\subsection{The procurement procedure}

The study examined in detail the type of award procedure used ${ }^{83}$, since theory suggests that this affects integrity risks ${ }^{84}$, although such risks depend also on the institutional environment (itself a major factor in choosing appropriate procedures) ${ }^{85}$ and, as noted, the impact of transparent procedures as an integrity tool may also be limited, especially where corruption is endemic.

Various classifications are possible, but for studying integrity risks we chose a three-fold classification. A precise definition of each type of procedure was important, since (as explained below) labels such as "open" or "restricted" are attached to quite different procedures in different systems. All three of our types have different legal and practical features in different systems - such as whether negotiations are allowed/used - some of which were captured, but the classification focused on features that are almost universal in international transparency instruments.

The first type we called an "open public tender". This was defined as a tendering procedure in which there is a public solicitation of offers and under which all interested suppliers have a right to be considered in accordance with objective criteria. This definition covers, among other procedures, open tendering under the UNCITRAL Model Law 2011 and the GPA and the EU directives' open procedure. It covers certain procedures that limit submission of offers to pre-qualified suppliers (those that have undergone a prequalification stage so that they meet minimum conditions, such as technical competence) (and to that extent is wider than open tendering/open procedures under the GPA ${ }^{86}$ and EU directives ${ }^{87}$, which (unlike the UNCITRAL concept ${ }^{88}$ ) do not cover procedures with pre-qualification, although nothing much turns on this since procedures allowing pre-qualification are anyway also freely available under the GPA and EU Directives). This is because the timing of the qualification exercise was not considered to affect significant integrity risks significantly (although the existence of pre-qualification was identified where possible).

Our definition of open public tender also covered procedures that allow the procuring entity to limit the number of qualified suppliers to tender based on objective criteria (called "reduction of numbers" under the EU directives), generally done to reduce the costs of preparing and evaluating tenders in complex procurements. This includes procedures referred to as selective tendering under the GPA and restricted tendering, competitive procedure with negotiation and competitive dialogue under the EU

\footnotetext{
${ }^{83}$ The analysis looked at the procedure actually followed, where this information was available, as well as the legal "type" of procedure invoked, since a single legal type can cover a variety of forms (e.g. the EU's restricted procedure and competitive dialogue that were used for some events (see the event summary for the London 2012 Olympics) allows both for a form in which all number of qualified suppliers are invited, or merely some of these are selected (the "reduction of numbers" process).

${ }^{84}$ On the different types of award procedure in legal frameworks see generally S. Arrowsmith, J. Linarelli and D. Wallace Jr., Regulating Public Procurement: National and International Perspectives (London: Kluwer Law International, 2000), Ch.1; S. Arrowsmith (ed.), Public Procurement Regulation: An Introduction (EU Asia Inter University Network for Teaching and Research in Public Procurement Regulation, 2011) at

https://www.nottingham.ac.uk/pprg/documentsarchive/asialinkmaterials/publicprocurementregulationintroduct ion.pdf; P. Trepte, Regulating Procurement: Understanding the Ends and Means of Public Procurement Regulation (Oxford: Oxford University Press, 2004).

${ }^{85} \mathrm{~A}$ point reflected in the variety of procedures provided for in the UNCITRAL Model Law on Public Procurement 2011, not all of which are intended to be adopted for every enacting state: see UNCITRAL, "Guide to Enactment of the UNCITRAL Model Law on Public Procurement", pp.129-130, at https://www.uncitral.org/pdf/english/texts/procurem/ml-procurement-2011/Guide-Enactment-Model-LawPublic-Procurement-e.pdf.

${ }^{86}$ GPA 2012, art.I $(m)$.

87 For the details of the EU's open procedure see S. Arrowsmith, The Law of Public and Utilities Procurement: Regulation in the EU and UK, 3rd edn (London: Sweet \& Maxwell, 2014), Vol.1, in particular Ch.7 and Ch.12. 88 UNCITRAL Model Law on Public Procurement 2011, art.18(1).
} 
directives. This is wider than UNCITRAL's open tendering concept, which does not allow this, although the Model Law provides for alternatives that do allow it when a specific justification applies ${ }^{89}$. Although the extra discretion increases corruption risks and the potentially limited number of participants increases risks of collusion, the former is limited when the tenderers are chosen using pre-stated objective criteria, and this is reflected in the GPA and EU directives allowing such a phase in their "default" procedures (that is, where no justification for use is required). However, again, our study identified the existence of such a phase where possible. Our definition also included procedures involving negotiation or other dialogue. This is potentially valuable in infrastructure procedures - for example, to identify different solutions, to reduce the risk of noncompliant tenders or misunderstandings, or to address collusion risks ${ }^{90}$. However, it is also considered to increase corruption risks in certain respects, so that UNCITRAL and the main EU directive for the public sector (Directive 2014/24/EU) allow this only in specified circumstances. Again, procedures involving dialogue were thus specifically identified.

A further complication arises from the practice in some cases of limiting access to those registered on supplier lists. Where the list used is openly advertised and accessible without delay or other obstacles - as required, for example, with lists subject to the GPA $^{91}$ - and there is also open solicitation for the specific procurement sufficient to allow registration in time, then the procurement is considered open for our purposes. Where the list meets these criteria but there is no open solicitation for the specific procurement, on the other hand, or even when there is no reasonable time for suppliers in general to register after the open solicitation, the openness of the procedure can be considered to be qualified in some degree in practice, as it may exclude some who did not consider it worth investing in registering in general for the market but might have been interested in that specific opportunity. We classify all procedures using open and accessible lists as open procedures but specifically refer to the qualifications above where they exist.

Our second type of procedure was a restricted invitation, referring to a competitive procedure involving no open solicitation but merely an approach to two or more suppliers. Restricted tendering under the UNCITRAL Model Law falls into this category, as do other Model Law procedures that allow direct solicitation of bids in certain circumstances (such as the competitive procedure with negotiations). Such procedures are envisaged by UNCITRAL only in exceptional circumstances, such as urgency ${ }^{92}$, for larger procurements ${ }^{93}$, and the EU directives and GPA do not include explicit procedures of this kind (allowing direct awards, however, in some cases of urgency in which UNCITRAL prefers this competitive approach) ${ }^{94}$. The absence of openness in terms of who can access the procedure, and consequent lack of control over the procuring entity's selection of participants, means that corruption risks are much greater than with open public tendering. In some countries the legal and/or other rules may allow an award without any competition at all, but the procuring entity chooses to hold a competition

\footnotetext{
${ }^{89}$ E.g., under art.30, request for proposals with dialogue - which allows this according to notified objective criteria - and competitive negotiations.

${ }^{90}$ For discussion of some of these points see, e.g., P. Bajari and S. Tadelis, "Incentives and award procedures: competitive tendering vs. negotiations in procurement", in N. Dimitri, G. Piga and G. Spagnolo (eds), Handbook of Procurement (Cambridge: Cambridge University Press, 2006), Ch.5, pp.121-142; K. Krueger, "The Scope for Post-tender Negotiations in International Tendering Procedures", in S. Arrowsmith and A. Davies (eds), Public Procurement: Global Revolution (London: Kluwer Law International, 1999), Ch.10.

${ }_{91}^{91}$ GPA Art.IX.

92 Art.30(4) of the Model Law.

${ }^{93}$ It can be noted that the UNCITRAL Guide to Enactment (of the Model Law on Public Procurement) generally counsels against such procedures, which can often now be avoided by setting up transparent mechanisms for a more open approach to lower value procurement, for example, using electronic tools.

${ }_{94}$ The Model Law's general urgency procedure is competitive negotiations as provided in art.30(4)(a), with direct award permitted on urgency grounds only in cases of a catastrophic event (art.30(5)(b)), whereas the GPA (art.XIII(1)(d)) and EU directives (e.g. Directive 2014/24, art.32) allow direct award as a more general procedure for extreme urgency (although its use should be rare under the directives because of the possibility for accelerated open and restricted procedures).
} 
between invited parties. In this case we classify a procedure as a restricted invitation procedure, based on its de facto operation.

The third type of procedure was the direct award, namely a procedure without a competitive process. Use of such procedures significantly increases corruption risks (as well as risks to other procurement objectives), and its use is strictly limited by most procurement frameworks - including UNCITRAL ${ }^{95}$, the GPA ${ }^{96}$ and the EU directives ${ }^{97}$ - as well as subject to various procedural controls ${ }^{98}$. As noted above, where the law or policy allows for a procedure without a competition but competition was held in practice, this has been classified as a restricted invitation.

As IPACS reports, nearly all the 75 infrastructure procurements ${ }^{99}$ studied for that report for which information was available (71 of the 75) open public tender was used, with no restricted invitations in a competitive form and a direct award only in three cases ${ }^{100}$. Of the open public tenders for which information was available, 29 of 61 involved prequalification. Sometimes, however, (as with Buenos Aires and South Africa) participation was limited to suppliers pre-registered on a list, when ease of access to specific openly solicited procurements depends on ease of access to the list. In the case of the Gold Coast, 4 of the 7 procurements were done by a qualified open method, open to all those on a list that was open and continuously accessible list, as outlined later, with only very small procurements using other methods.

The limited use of direct awards may to some extent reflect fact that, as we have seen, the choice of mapping targets was influenced, at event, infrastructure and procurement level, by availability of information. For example, this influenced the procurements chosen for mapping at New Delhi, for which other sources highlight that direct awards were used; and for some events (including Vancouver and Sochi) there is simply insufficient information to assess the use of direct awards. However, it is at least clear that for most of the events studied (including New Delhi) an open public tender was used for at least the bulk of significant infrastructure. Of the two additional events, the significant Gold Coast procurement was done by a qualified open approach as just noted. However, Budapest presented a very different picture, with a restricted invitation being used for all six major sport-specific infrastructure contracts based on alleged urgency, as the event summary explains. Such a scenario presents a clear red flag for integrity risks, and we will see that this event attracted considerable media criticism over value for money and conflicts of interest.

Events varied on including discussions with suppliers in open public tenders. These featured at London, where the procurements for both the stadium and aquatics centre used an open public tender that allowed for this (and only one bid was received for the stadium procurement); in two of the three procurements for which information was available for Sochi (not surprisingly given the quasi-public character of the procuring entity and flexible procurement framework); and at New Delhi, where there were discussions in several infrastructure procurements. However, for most events mapped for IPACS either there was no information or, as with Rio, or procedures allowing for

\footnotetext{
95 UNCITRAL Model Law on Public Procurement 2011, arts 27-28, and the conditions on use of direct awards in art.30.

96 GPA 2012, art.XIII.

97 E.g. Public Contracts Directive, art. 32.

${ }^{98}$ E.g. the Model Law requires (as in all case when open tendering is not used) justification of reasons in the record (art.28(3)) and (as for other procurements in which there is no public solicitation) must in most cases publish a public notice to inform interested parties of the procurement: art.34(5).

${ }_{99}$ We exclude here the construction services procurement from the 2016 London Olympics, which IPACS included.

100 The Handball Olympic Centre/Future Arena at the Rio 2016 Olympics (but apparently following an open public tender in which there were no bidders, which provides a legal basis for a direct award); the Sambódromo improvement works at the 2016 Rio Olympics, justified by an urgency derogation; and exterior works on the Xalapa Velodrome at the 2014 Veracruz Central American and Caribbean Games 9for which a recorded justification was not found): see the relevant event summaries later in this article.
} 
discussions were not used. While negotiation is considered a red flag for corruption risk these events varied in the extent of perceptions of integrity, however, with the mapped procurement for London being generally considered "clean"101, and use of discussions merely reflecting common UK practice for complex infrastructure procurement ${ }^{102}$. Of the procedures for which information was available only those for London (stadium, aquatics centre and velodrome) appeared to allow a reduction of numbers process, again reflecting UK practice ${ }^{103}$.

As regards award criteria, as IPACS noted ${ }^{104}$, for those procurements for which information was available (58) $86 \%$ used only lowest price. While this can reduce abuse of discretion it can also lead to insufficient attention to non-price dimensions and facilitate supplier collusion.

All the IPACS events were conducted under procurement frameworks providing a supplier review system, considered an essential feature of a modern procurement system and required under, for example, the UNCITRAL Model Law ${ }^{105}$, GPA ${ }^{106}$ and EU procurement directives ${ }^{107}$, as well as under the United Nations Convention Against Corruption (UNCAC) ${ }^{108}$. As the summaries report, there were challenges to one or two mapped procurement, notably for Wroclaw. There is no information of an adverse impact of the events, however, although at Wroclaw it meant that some infrastructure was only just finished in time.

It is clear from the events studied that for the tendering phase applicable procurement laws generally provide for open public tendering in line with international standards and that this is generally followed. The main issues from an integrity perspective generally arise not from the adequacy of the formal framework but from use of exceptions, whether lawfully or unlawfully, including because of poor planning, and from the manner of conducting procurement within the legal framework, such as planning and choice of award criteria.

\subsection{Contract execution}

Inadequate control over contract execution gives rise to significant corruption risks, including the controls over the award phase being undermined by amendments (for example, minor extensions for large payments that undermine the contract's economic balance). Infrastructure projects are in general prone to renegotiation and, as IPACS highlights, the time critical nature of sporting infrastructure can produce particular pressures ${ }^{109}$; and amendment were seen in many of the mapped projects. Since most national regimes impose legal controls over execution phase such controls were found to a degree, but, as highlighted earlier, transparency was often lacking in this phase.

\subsection{Reported integrity problems}

Of the ten IPACS events, five, namely Sochi, Guangzhou, Rio, Veracruz and New Delhi, produced significant corruption allegations by audit bodies, media and/or NGOs, as described in the event summaries, in most cases leading to arrests or convictions; while South Africa involved significant bid-rigging, as well as allegations of other

\footnotetext{
101 See the event summary for London.

102 See the event summary for London.

103 See the event summary for London.

104 IPACS report, p.40.

105 UNCITRAL Model Law on Public Procurement 2011, Ch.VIII.

106 GPA 2012, art.XVIII.

107 E.g. Council Directive 89/665/EEC of 21 December 1989 on the coordination of the laws, regulations and administrative provisions relating to the application of review procedures to the award of public supply and public works contracts [1989] O] L395/33.

108 United Nations Convention against Corruption, art.9(1)(d).

109 IPACS report, p.31.
} 
irregularities ${ }^{110}$. A further event in our study, Budapest, both involved extensive use of non-open procedures and attracted media criticism for extensive waste and cronyism ${ }^{111}$. Other events, notably London and Vancouver, were praised by external bodies as "clean" events and may thus provide useful lessons although of course the environment in which these events took place was quite different from those in which integrity problems occurred. Lessons may also be learned, however, from events where integrity problems did occur but were brought to light: thus Spalding et al have argued that the legacy of the 2014 Brazil World Cup and of Rio has been important for addressing corruption in Brazil, in that, while the events were plagued with integrity problems, they provided a catalyst for new integrity measures that were successful in bringing to light and pursuing these problems, which previously might have remained hidden ${ }^{112}$.

\subsection{IPACS findings and proposals}

As IPACS has reported, the trends and patterns seen by mapping the initial ten events in the study has provided the foundations for IPACS to develop tools and practical guidelines for addressing integrity risks, and its report makes a number of findings and proposals.

First, the report concludes that mitigating these risks in procuring sporting infrastructure requires more strategic approaches to collecting information, in light of the limited public information (as we discussed earlier) and the difficulty IPACS experienced in collecting further data, noting that "The limitations of institutional memory observed constitute a significant obstacle to learning lessons from previous experiences......"113. Secondly, the report concludes that there is little evidence that strategies fostering competition, such as early market engagement, are systematically applied, despite the importance of genuine competition to mitigate integrity risks and the specific difficulties in ensuring such competition with major events. ${ }^{114}$ This reflects the fact that following rules on open public tenders cannot alone guarantee competition. Thirdly, the IPACS report stresses the importance of oversight in contract execution - an oversight that we have seen was little evidenced in the available information - to ensure that the benefits of tendering are not undermined. ${ }^{115}$

On this basis, the report proposes that stakeholders consider a number of steps. One is for international federations, governments, implementing agencies and oversight bodies to agree on strategies for centralising information ${ }^{116}$. Information for specific events should include a map of the responsibilities of the (often many and varied) entities involved and ensure a more strategic approach to risk management ${ }^{117}$. Comprehensive information could then also provide lessons for future events.

The report also highlights the need to consider recording procurement data, in a standard, consistent, error-free manner and in a searchable and otherwise usable form, and to ensure integration of data on award and execution ${ }^{118}$. This will, among other things, allow application of techniques for identifying red flags for integrity risks, including of collusion. As Hayman discusses, the Open Contracting system is one way in which this can be achieved ${ }^{119}$. Where made public, as envisaged by the Open Contracting approach, such data can also facilitate valuable monitoring by stakeholders.

\footnotetext{
110 See the events summaries.

${ }^{111}$ See the later event summary.

112 See the event summary for Rio.

113 IPACS report, p.38.

114 IPACS report, p.38.

115 IPACS report, pp.38-39.

116 IPACS report, p.39.

${ }^{117}$ IPACS report, pp.39-40.

118 IPACS report, p.40.

119 G. Hayman, "Better procurement for major sporting events: will we see open contracting for Paris 2024?" (2019) 28 P.P.L.R. xxx.
} 
In the light of the limited evidence of pre-tendering activities, the report also recommends giving greater attention to these, including early market engagement, and recommends considering whether existing general provisions are adequate for specific events ${ }^{120}$. Likewise, IPACS recommends a significant focus on contract execution, including governance mechanisms for amendments (to include clear processes for submitting and assessing amendment claims), and a structured approach to renegotiations ${ }^{121}$. For the tendering stage, an adequate legal framework generally exists, and the main problems concern compliance and use of exceptions, as we have seen; but the IPACS report also highlights some issues relating to practice within the framework, notably extensive use of lowest price, and recommends greater consideration to nonprice/cost criteria, to foster a better price/quality mix and also limit the risk of collusion $^{122}$.

Finally, the report stresses the need to consider clear internal and external reporting lines, including clear and communicated procedures for reporting integrity suspicions ${ }^{123}$; and for training on identifying bid rigging ${ }^{124}$.

The report concludes by proposing specific checklists for addressing the above issues, which IPACS will now build on to produce risk assessment tools (methodology and assessment questionnaire) for testing in a pilot project. The checklist for implementing agencies $^{125}$ deals with mapping the involvement of different stakeholders through the whole cycle; mapping of plans against delivery; provision of detailed guidance on pretender activities tailored to context; consideration of whether there is an understanding of bid rigging and the relevant red flags; collection of information on the actual extent of competition; collection of information on amendment claims; and provision for periodic risk assessments that include identifying and responding to integrity risks. For governments and sport federations the checklist covers ${ }^{126}$ suitability of the procurement workforce; adequacy of the current legal framework(s) for the agencies; provision of a comprehensive procurement strategy for the infrastructure as a whole; provision of an overall risk management strategy, including a specific focus on risk, a strategic approach, regular monitoring and evaluation and well-defined procedures and mechanisms for a co-ordinated response to problems; and existence of a dedicated entity for risk management of infrastructure procurement (suggesting that Vancouver and London provide good examples); provision of competitive procedures; the extent to which risks of bid rigging are understood and mitigated (including through advance consultation with competition agencies, provision for collecting data to flag up risks, and workforce education); use of appropriate non-price criteria; and provision of updates for the public on financial and physical progress.

\section{Events summary}

\subsection{Introduction}

In this section we now outline the key findings on an event-by-event basis to put the information in context.

\subsection{Olympic and Paralympic Games, London, England, 2012}

There was a reasonable amount of public information on infrastructure procurement for London. First, key information was available for open public tenders from the public

\footnotetext{
${ }^{120}$ IPACS report, pp.40-43.

${ }^{121}$ IPACS report, p.41.

122 IPACS report, p.40.

${ }^{123}$ IPACS report, p.40.

124 IPACS report, p.40.

125 IPACS report, pp.42-45.

${ }^{126}$ IPACS report, pp.45-49.
} 
notices (advance notification of the procurement ${ }^{127}$, solicitation notices and award notices) required by law in the Official Journal of the European Union (OJEU). While at the time of the research (2018) notices were no longer publicly available online as they are archived after 5 years, the OJEU provided them on request. Other significant procurement information was also available online, including on a "learning legacy" event site ${ }^{128}$, with information such as the infrastructure Procurement Policy ${ }^{129}$, a document on Use of the competitive dialogue procedure ${ }^{130}$ and a Suppliers' Guide ${ }^{131}$. The site does not contain the annual reports and accounts of the Olympic Delivery Authority (ODA) (the main entity responsible for infrastructure procurement: see below), but some are available elsewhere ${ }^{132}$. Other information was accessible using the Freedom of Information Act 2000 and the government provided some of this in an expedited manner to assist our research ${ }^{133}$. Procurement information was also available in a paper whose authors included key players in the procurement ${ }^{134}$ and in other literature and commentary $^{135}$. However, much information that might otherwise have been obtained,

${ }^{127}$ Required at the time for the procurement of the delivery partner (as to which see below) but not other mapped procurements, which were launched after entry into force of the Public Contracts Regulations 2006 (SI 2006/5) on 31 January 2006, which no longer included such a requirement; thus publication of advance notices for these procurements was on a voluntary basis.

${ }^{128}$ https://webarchive.nationalarchives.gov.uk/20180426101359/http://learninglegacy.independent.gov.uk/. 129 [2007] Olympic Delivery Authority, "Procurement Policy", at

https://webarchive.nationalarchives.gov.uk/20130403015932/http://learninglegacy.independent.gov.uk/public ations/procurement-policy.php.

${ }^{130}$ [2011] Olympic Delivery Authority, "Competitive Dialogue", at

https://webarchive.nationalarchives.gov.uk/20130403015937/http://learninglegacy.independent.gov.uk/public ations/competitive-dialogue.php.

${ }^{131}$ [2011] Olympic Delivery Authority, "Supplier Guide", at

https://webarchive.nationalarchives.gov.uk/20130403015934/http://learninglegacy.independent.gov.uk/public ations/supplier-guide.php.

132 Annual report and accounts for each of the financial years 2006-2014 and the accounts for the final

months of 2014, published by the Olympic Delivery Authority:

2006-2007 at

https://assets.publishing.service.gov.uk/government/uploads/system/uploads/attachment_data/file/250791/0 741.pdf;

2007-2008 at

https://assets.publishing.service.gov.uk/government/uploads/system/uploads/attachment_data/file/250261/0

645.pdf;

2008-2009 at

https://assets.publishing.service.gov.uk/government/uploads/system/uploads/attachment_data/file/248269/0 636.pdf;

2009-2010 at

https://assets.publishing.service.gov.uk/government/uploads/system/uploads/attachment_data/file/247722/0

155.pdf;

2010-2011 at

https://assets.publishing.service.gov.uk/government/uploads/system/uploads/attachment_data/file/247253/1

360.pdf;

2011-2012 at

https://assets.publishing.service.gov.uk/government/uploads/system/uploads/attachment_data/file/88754/OD A_Annual_Report_and_Accounts_2011-2012.pdf;

2012-2013 at

https://assets.publishing.service.gov.uk/government/uploads/system/uploads/attachment_data/file/223522/O DA_Annual_Report__Accounts_2012-2013.pdf;

2013-2014 at

https://assets.publishing.service.gov.uk/government/uploads/system/uploads/attachment_data/file/336720/O DA_AR_2014_Low_res_composite.pdf;

April 1, 2014 - December 2, 2014 at

https://assets.publishing.service.gov.uk/government/uploads/system/uploads/attachment_data/file/412429/O DA_AR_2014_-_Web_PDF.pdf.

${ }^{133}$ Such as a draft of a paper provided by the National Audit Office, Review of Olympic Delivery Authority: Data Assurance and Reporting. Final Report for the National Audit Office (May 2009) [name of author redacted by the National Audit Office]. No explanation was given as to why a draft, rather than final, version was provided. The document contains information on the overall governance, process and structure for data reporting as well as a review of the delivery partner's cost and performance.

${ }_{134}$ M. Cornelius, J. Fernau, P. Dickinson and M. Stuart, "Delivering London 2012: procurement" (2011) 164:5 Proceedings of the Institution of Civil Engineers - Civil Engineering 34.

${ }^{135}$ See, in particular, J.M. Mead and S. Gruneberg, Programme Procurement in Construction: Learning from London 2012 (Oxford: Wiley-Blackwell, 2013); P. Stanlislas, "Tackling Corruption and Crime in Public 
including under the Freedom of Information Act, was not available as a result of the ODA's being wound up and existing public bodies being unable to locate the information that had, according to anecdotal evidence, been retained and transmitted to these entities $^{136}$. In particular, other than as stated above the sources did not reveal primary documentation, including bid documentation or contracts.

Of the 112 significant construction contracts ${ }^{137}$, mapping covered those for the three major new permanent sporting venues, namely the Olympic Stadium, Aquatics Centre and Velodrome - all new constructions by a single contractor - and also a procurement for roads, bridges and certain other structures within or adjacent to the Olympic Park ${ }^{138}$. The anticipated final cost of each stated in the Games' June 2012 Quarterly Report was respectively USD596.80m (£428m), USD349.99m (£251m), 121m USD ( $£ 87 m$; for the Velopark) and $787.84 \mathrm{~m}$ USD $(£ 565 \mathrm{~m})^{139}$.

The body responsible for procuring infrastructure and venues was the ODA, a Nondepartmental public body ${ }^{140}$ established by statute ${ }^{141}$ for the event with nearly 400 personnel. They worked in partnership with a delivery partner, CLM (a consortium), chosen by open public tender ${ }^{142}$ to manage the delivery, planning, design, construction, commissioning, maintenance, conversion to legacy mode and cost management of the infrastructure procurement ${ }^{143}$ - an innovative approach to ensure suitable human resource capacity, which the evidence suggests was successful and a potential model for future events, given the success in delivery (see below) and value for money of the arrangement ${ }^{144}$. The Local Organising Committee, the London Organising Committee of

Procurement in the 2012 London Olympics and Paralympics Games: The Role of Operation Podium, The Specialist Organized, and Economic Crime Unit of the Metropolitan Police", in P. Gottschalk and P. Stanislas, (eds), Public Corruption: Regional and National Perspectives on Procurement Fraud (Boca Raton: CRC Press, 2017), Ch.7, pp.107-127; P. Smith, "The Olympics 'Delivery Partner' model - a precedent worth following? (Part 1)" (2012), retrieved from http://spendmatters.com/uk/olympics-delivery-partner-model-precedentworth-following-part-1/; P. Smith, "The Olympics 'Delivery Partner' model - a precedent worth following? (Part 2)" (2012), retrieved from http://spendmatters.com/uk/oda-2/; J. Timms, "A socially responsible business legacy: raising standards in procurement, supply chains and employment at the London Olympics of 2012", in R. Holt and D. Ruta (eds), Routledge Handbook of Sport and Legacy: Meeting the Challenge of Major Sports Events (London: Routledge, 2015), Ch.15, pp.217-228; D. Von Plessen, The procurement strategies for the Olympic Stadium and the Aquatic Centre for the London 2012 Olympic Games (Hamburg: Anchor Academic Publishing, 2015); K. Carpenter, "Preventing corruption ahead of major sports events: learning from the 2012 London Games", in Transparency International, Global Corruption Report: Sport (Abingdon: Routledge, 2016), Ch.3.9, pp.178-182, available via https://www.transparency.org/whatwedo/publication/global_corruption_report_sport.

136 Separate Freedom of Information requests were made to the Department for Culture Media and Sport (DCMS), HM Treasury (HMT) and the Cabinet Office (CO) for procurement records for the Stadium, Velodrome and Aquatics Centre. It was understood that the records may lie with the Infrastructure and Projects Authority, which reports to both the CO and HMT. HMT advised that the ODA records were held by DCMS. However all these requests failed to locate any documentation or definitive knowledge of where it was.

137 M. Cornelius, J. Fernau, P. Dickinson and M. Stuart, "Delivering London 2012: procurement" (2011) 164:5 Proceedings of the Institution of Civil Engineers - Civil Engineering 34.

138 The actual price is not known as it was withheld in the contract award notice.

139 Department for Culture, Media and Sport, "London 2012 Olympic and Paralympic Games Quarterly Report" (June 2012), p.17, at

https://assets.publishing.service.gov.uk/government/uploads/system/uploads/attachment_data/file/78228/DC MS_GOE_QR_JUNE-2012.pdf. The respective values are in USD, converted at USD $\$ 1.3943989656 / £ 1$, the conversion rate at xe.com as at 21.2.2018 when most of the research was completed.

140 Under the Department for Culture, the Media and Sport, and under the supervision of an overall Olympic Board made up of the Secretary of State for Culture, Media and Sport Mayor of London, Chair of the British Olympic Association, Chair of the Local Organising Committee, LOCOG, and Chair of the ODA itself (a nonvoting member). The board of the ODA was appointed by the Minister for Olympics and Paralympics.

${ }^{141}$ The London Olympic and Paralympic Games Act 2006.

142 The competitive dialogue procedure under the Public Contracts Regulations 2006 (SI 2006/5), which was one of the first uses of this procedure in the UK.

${ }^{143}$ On this arrangement see M. Cornelius, J. Fernau, P. Dickinson and M. Stuart, "Delivering London 2012: procurement" (2011) 164:5 Proceedings of the Institution of Civil Engineers - Civil Engineering 34.

${ }_{144}$ P. Smith, "The Olympics 'Delivery Partner' model - a precedent worth following? (Part 1)" (2012), at http://spendmatters.com/uk/olympics-delivery-partner-model-precedent-worth-following-part-1/; P. Smith "The Olympics 'Delivery Partner' model - a precedent worth following? (Part 2)" (2012), at http://spendmatters.com/uk/oda-2/. 
the Olympic and Paralympic Games (LOCOG), had responsibility for some finalisation works and installation of spectator facilities, as well as procurement of supplies and services used for the Games, but not for major infrastructure ${ }^{145}$. The ODA was covered by the regular public procurement legal framework of England and Wales ${ }^{146}$, deriving almost wholly from EU procurement law. (LOCOG, on the other hand, was a private company limited by guarantee which, because of its make-up, considered itself outside that framework. ${ }^{147}$ )

The ODA carefully assessed design options for the sporting infrastructure ${ }^{148}$, choosing for the stadium being simple Design and Build by a single contractor, whereas with the Aquatics Centre and Velodrome a basic design was obtained separately and novated to the (single) construction contractor ${ }^{149}$. The procurements were financed directly by the ODA and taken into public sector ownership ${ }^{150}$.

A feature of London was the attention to planning, including market engagement and research; this was used to design careful procurement strategies on issues such as packaging of work to attract bidders ${ }^{151}$, with an integrated approach facilitated by centralisation of infrastructure procurement in the ODA. Advance notices ahead of the solicitation were found in the OJEU for all the mapped procurement other than the stadium $^{152}$.

In addition, London was one of only four of the 14 projects for which evidence of significant risk management activity was publicly available. It provided perhaps the most comprehensive illustration of such activity, both in general and in relation specifically to both integrity risks and procurement ${ }^{153}$. In 2005 the Metropolitan Police Economic Crime Command produced a document, "Who Will Win Gold?", outlining economic crime risks and the author was then tasked with further analysis of both previous successful Games and major UK construction projects. The Specialist, Organised and Economic Crime Unit of the Metropolitan Police then established Operation Podium in 2006 to target such risks in the Games and worked in close partnership with the ODA. The Construction Industry Fraud Forum (CIF) was established by Operation Podium to improve understanding of risks by the industry, police and ODA. Special funds from Home Office were used to

${ }^{145}$ P. Cummings, D. Stubbs and G. Walsh, [LOCOG], "Sustainable procurement - the London 2012 Olympic Games and Paralympic Games" (Learning legacy: Lessons learnt from planning and staging the London 2012 Games, December 2012), p.2, at

https://webarchive.nationalarchives.gov.uk/20130228084558/http://learninglegacy.london2012.com/publicati ons/sustainable-procurement-the-london-2012-olympic-games-an.php?stylesheet=normal.

${ }_{146}$ At that time the 2004 Public Procurement Directive 2004/18/EC, transposed by the Public Contracts Regulations 2006 (SI 2006/5).

147 LOCOG was formed by the Minister for the Olympics and London, the Mayor of London and the BOA which, like the ODA, was under the overall Olympic Board. LOCOG raised income through sources that included ticket sales, sponsorship, merchandising and the International Olympic Committee as well as receiving some public money.

${ }_{148}$ D. Von Plessen, The procurement strategies for the Olympic Stadium and the Aquatic Centre for the London 2012 Olympic Games (Hamburg: Anchor Academic Publishing, 2015).

${ }^{149}$ As indicated in the contract notices; and on the Stadium and Aquatics Centre see further D. Von Plessen, The procurement strategies for the Olympic Stadium and the Aquatic Centre for the London 2012 Olympic Games (Hamburg: Anchor Academic Publishing, 2015).

${ }^{150}$ None of the mapped procurements planned the use of private financing. Arrangements for the one significant procurement that did, the Olympic Village, collapsed in the credit crunch, resulting in a massive public subsidy and possibly contributing to the affordable housing legacy being curtailed: see A. Zimbalist, Circus Maximus: the economic gamble behind hosting the Olympics and the World Cup, 2nd edn (Washington, D.C.: Brookings Institution Press, 2016), pp.121-122.

${ }^{151}$ See e.g. M. Cornelius, J. Fernau, P. Dickinson and M. Stuart, "Delivering London 2012: procurement" (2011) 164:5 Proceedings of the Institution of Civil Engineers - Civil Engineering 34.

152 Structures and bridges [2007] OJ/S 020/023201; Aquatics Centre [2006] OJ/S 246/264303; Delivery partner [2005] OJ/S 073/070688; Velodrome [2007] OJ/S 026/031062. These notices are now archived and not available directly online. The solicitation (contract notice) for the stadium confirms there was no advance notice for that.

${ }^{153}$ Contained in the ODA's annual reports and accounts and quarterly risk report, required under Section 5 of ODA Procurement Policy Document: [2007] Olympic Delivery Authority, "Procurement Policy", at https://webarchive.nationalarchives.gov.uk/20130403015932/http://learninglegacy.independent.gov.uk/public ations/procurement-policy.php. 
allocate dedicated crime prevention officers to work with the ODA, and two police officers from Operation Podium were embedded into the ODA's workforce to advise and to support managers in identifying risks and areas of vulnerability in the procurement and how to mitigate them. ${ }^{154}$. As IPACS concludes: "This example serves as an illustration of an organiser investing resources into a strategic approach for managing corruption risks." ${ }^{155}$ It also illustrates the potential legacy of sporting events for improved procurement, with the post-event audit concluding that the experience with the Games had enhanced public sector experience and capacity in managing risk ${ }^{156}$.

The legal framework offered four types of open public tender, the open and restricted procedures - single-stage tendering open to all interested parties and freely available and the more flexible competitive dialogue and the negotiated procedure with a call for competition, available only in justified cases, which allowed for dialogue and an iterative process, and gave entities considerable freedom in designing the procedure ${ }^{157}$. All but the open procedure allow for pre-qualification and reduction of numbers and such phases were envisaged by the solicitations. The procedures chosen were negotiated for the stadium (the most complex), competitive dialogue for the Aquatics Centre (and also the delivery partner) and restricted for the Velodrome and roads/bridges ${ }^{158}$. The use of flexible procedures for the most complex projects was in line with the general approach to complex infrastructure procurements in the UK in the light of what was widely perceived as an appropriate balance between transparency and discretion for achieving value for money in the UK environment ${ }^{159}$. The ODA's procurement policy had a specific focus on overall value rather than $\operatorname{cost}^{160}$, including a comprehensive programme for integrating sustainability concerns ${ }^{161}$. This was reflected in, among other things, the fact that none of the mapped procedures used cost-only award criteria (prohibited by law anyway for competitive dialogue $)^{162}$. The ODA's Suppliers Guide states that the procurement processes, including document submission, were to be electronic ${ }^{163}$, although some negotiation and other dialogue also took place (as explained below) that

\footnotetext{
154 P. Stanlislas, "Tackling Corruption and Crime in Public Procurement in the 2012 London Olympics and Paralympics Games: The Role of Operation Podium, The Specialist Organized, and Economic Crime Unit of the Metropolitan Police", in P. Gottschalk and P. Stanislas, (eds), Public Corruption: Regional and National Perspectives on Procurement Fraud (Boca Raton: CRC Press, 2017), Ch.7, pp.107-127.

155 IPACS report, p.34.

156 National Audit Office, The London 2012 Olympic Games and Paralympic Games: post-Games review, Report by the Comptroller and Auditor General, HC 794, Session 2012-13, 5 December 2012 (London: The Stationery Office, 2012), available at https://www.nao.org.uk/wp-content/uploads/2012/12/1213794fr.pdf.

${ }^{157}$ On these procedures in general as they existed at that time and their subsequent legal development see $\mathrm{S}$. Arrowsmith, The Law of Public and Utilities Procurement: Regulation in the EU and UK, 3rd edn (London: Sweet \& Maxwell, 2014) Vol.1.

158 The solicitations were: aquatics centre [2006] OJ/S 053/065342; delivery partner [2006] OJ/S 033/036394; stadium [2006] OJ/S 139/149240; roads and bridges [2007] OJ/S 061/074704. These are now archived and not available directly online.

${ }^{159}$ See generally P. Braun, "Strict Compliance versus Commercial Reality: The Practical Application of EC Public Procurement Law to the UK's Private Finance Initiative" (2003) 9 European Law Journal 575; S. Arrowsmith and R. Craven, "Competitive dialogue in the United Kingdom", in S. Arrowsmith and S. Treumer (eds), Competitive Dialogue in EU Procurement (Cambridge: Cambridge University Press, 2012), Ch.3, pp.181-271. 160 [2007] Olympic Delivery Authority, "Procurement policy" in full, at https://webarchive.nationalarchives.gov.uk/20120403103002/http://www.london2012.com/publications/odaprocurement-policy-in-full.php.

${ }^{161}$ This was not specifically a subject of our mapping exercise which, as noted, focused on integrity. For information on this see the Learning Legacy Website,

https://webarchive.nationalarchives.gov.uk/20180426101359/http://learninglegacy.independent.gov.uk/; M. Cornelius, J. Fernau, P. Dickinson and M. Stuart, "Delivering London 2012: procurement" (2011) 164:5 Proceedings of the Institution of Civil Engineers - Civil Engineering 34; J. Timms, "A socially responsible business legacy: raising standards in procurement, supply chains and employment at the London Olympics of 2012", in R. Holt and D. Ruta (eds), Routledge Handbook of Sport and Legacy: Meeting the Challenge of Major Sports Events (London: Routledge, 2015), Ch.15, pp.217-228.

${ }^{162}$ For example, the advertised criteria and weightings for the Aquatics Centre were price (30\%); acceptance of contractual terms $(10 \%)$; quality and functionality $(15 \%)$; project delivery $(25 \%)$; experience and capability $(10 \%)$; and governance (10\%): see Aquatics centre contract award notice: [2008] OJ/S 092/124113.

163 [2011] Olympic Delivery Authority, "Supplier Guide", p.9, at

https://webarchive.nationalarchives.gov.uk/20130403015934/http://learninglegacy.independent.gov.uk/public ations/supplier-guide.php.
} 
may not have been electronic in form. There were no legal challenges relating to the mapped procurements or, indeed, any others ${ }^{164}$, although this should be seen in the context of the UK's generally low level of procurement litigation ${ }^{165}$.

Although careful market analysis and engagement generally led to a reasonable response ${ }^{166}$ (including three bids for the Velodrome and three and four for the two lots for the road and bridges procurement) this was conspicuously not the case for the key procurements of the stadium, for which only one plausible bidder expressed interest resulting in an award by negotiation, and Aquatics Centre, involving three potential bidders in the initial dialogue but only one actual bid ${ }^{167}$. Those involved have ascribed the poor response to these projects being unattractive in a buoyant market given the high risk arising from their novelty, request for novation of the design of the Aquatics Centre, a fixed timescale, and the projects' high profile ${ }^{168}$. This illustrates that, while the high profile of an event could attract interest because of a chance to build a reputation, it can also reduce interest because of potential reputational damage. It can also be noted that the procurement for the stadium was launched before the procurement structure for the ODA was fully in place. It is difficult to know whether better value would have been obtained from greater competition.

There was an extensive formal system for controlling financial payments and reporting progress (including publicly), as well as provision for internal and external audit ${ }^{169}$. Amendments were controlled by legal rules deriving from EU law that, inter alia, prohibit substantial amendments or those changing the contract's economic balance in favour of the contractor, but otherwise it is not known what rules and processes governed amendments. There was, at the relevant time, no obligation on, or practice of, publishing amendments and other contractual information, although subsequently such a policy was introduced for central government ${ }^{170}$.

There were very few public suggestions of integrity problems at the time. Some concern was raised over the fact that the contractor for the Olympic Village (not one of the mapped procurements) was originally to be a company previously headed by the thenchief executive of the ODA but the original approach, which involved private finance, collapsed $^{171}$; and there was also a serious incident of fraud in which the ODA was duped

\footnotetext{
${ }^{164}$ M. Cornelius, J. Fernau, P. Dickinson and M. Stuart, "Delivering London 2012: procurement" (2011) 164:5 Proceedings of the Institution of Civil Engineers - Civil Engineering 34.

${ }^{165}$ As compared with many other countries, including most EU Member States. See European Commission, Economic efficiency and legal effectiveness of review and remedies procedures for public contracts, Final Study Report, MARKT/2013/072/C (April 2015), available via http://ec.europa.eu/growth/single-market/publicprocurement/studies-networks/index_en.htm; S. Arrowsmith and R. Craven, "Public Procurement and Access to Justice: a Legal and Empirical Study of the UK System" (2016) 25 P.P.L.R. 227.

166 M. Cornelius, J. Fernau, P. Dickinson and M. Stuart, "Delivering London 2012: procurement" (2011) 164:5 Proceedings of the Institution of Civil Engineers - Civil Engineering 34.

167 D. Von Plessen, The procurement strategies for the Olympic Stadium and the Aquatic Centre for the London 2012 Olympic Games (Hamburg: Anchor Academic Publishing, 2015); M. Cornelius, J. Fernau, P. Dickinson and M. Stuart, "Delivering London 2012: procurement" (2011) 164:5 Proceedings of the Institution of Civil Engineers - Civil Engineering 34

${ }_{168}$ D. Von Plessen, The procurement strategies for the Olympic Stadium and the Aquatic Centre for the London 2012 Olympic Games (Hamburg: Anchor Academic Publishing, 2015); M. Cornelius, J. Fernau, P. Dickinson and M. Stuart, "Delivering London 2012: procurement" (2011) 164:5 Proceedings of the Institution of Civil Engineers - Civil Engineering 34.

${ }^{169}$ See for example [2015] Olympic Delivery Authority, "Report and Accounts" for the period April 1, 2014 to December 2, 2014, pp.19-23, at

https://assets.publishing.service.gov.uk/government/uploads/system/uploads/attachment_data/file/412429/O DA_AR_2014_-_Web_PDF.pdf.

170 See Crown Commercial Service, "Procurement Policy Note - Promoting Greater Transparency", Information Note PPN 02/17, December 2017, available at

https://assets.publishing.service.gov.uk/government/uploads/system/uploads/attachment_data/file/667054/1 7_v1.0.docx_1_1_.pdf.

${ }^{171} \mathrm{~A}$. Zimbalist, Circus Maximus: the economic gamble behind hosting the Olympics and the World Cup, 2nd edn (Washington, D.C.: Brookings Institution Press, 2016), p.121.
} 
into making a payment to a fraudster claiming to represent a contractor ${ }^{172}$, leading the ODA to tighten procedures. There have also been allegations, explored in detail in a recent book by Gillard, that concern not to tarnish the reputation of the Olympics influenced a cover-up of broader corrupt activity by and within the host London Borough of Newham ${ }^{173}$. However, the procurement for the event itself appears to have been generally successful from an integrity perspective, with Transparency International praising the event's "fair and transparent" procurement and construction activities ${ }^{174}$.

Despite this, based on operation and venue costs and other costs directly relating to the Games (that is, leaving aside indirect infrastructure, such as transportation), according to the Oxford Olympics Study ${ }^{175}$ London was easily the most expensive Summer Olympics ever (although not as expensive as the Sochi Winter Olympics) ${ }^{176}$ and also had the highest cost per event and per athlete ${ }^{177}$. Overall costs increased three-fold from the bid to host the Games to completion ${ }^{178}$; and the operational and sporting costs overran by $76 \%{ }^{179}$, higher than the $51 \%$ median of post- 1999 Olympics and even higher than the average $75 \%$ (which is significantly affected by very high overruns at Sochi ${ }^{180}$ ). The stadium and Aquatic Centre cost nearly, or more than, double the original estimate ${ }^{181}$. The budget was, however, adjusted accordingly in December 2007 before most work began (although well into the procurement processes for the stadium and Aquatics Centre, after procurement for the design for the latter) and thereafter the final cost of the ODA infrastructure programme came in slightly under budget ${ }^{182}$ as did, for example, the stadium ${ }^{183}$. The programme was also completed in an appropriate and timely manner ${ }^{184}$. (The only major failure related not to infrastructure a LOCOG contract for

\footnotetext{
172 Detected by police when the fraudsters attempted to transfer funds abroad, and leading to criminal convictions for the fraudsters.

${ }^{173}$ M. Gillard, Legacy: Gangsters, Corruption and the London Olympics (London: Bloomsbury, 2019). The book also discusses integrity and state aid concerns raised over the initial successful tender for use of the stadium post-Games by West Ham United Football Club: see, in particular, Ch.13.

${ }^{174}$ R. Barrington, "Corruption and the Olympics" (Transparency International UK, News, Blog, 2012), retrieved from http://www.transparency.org.uk/corruption-and-the-olympics/\#.W3B5MegzbIU.

${ }^{175}$ As included and excluded respectively in the cost analysis in B. Flyvbjerg, A. Stewart and A. Budzier, "The Oxford Olympics Study 2016: Cost and Cost Overrun at the Games" (University of Oxford, Saïd Business School Research Papers, July 2016), at https://eureka.sbs.ox.ac.uk/6195/1/2016-20.pdf.

176 At a cost of USD 15 billion: for detail an costing methods used see B. Flyvbjerg, A. Stewart and A. Budzier, "The Oxford Olympics Study 2016: Cost and Cost Overrun at the Games" (University of Oxford, Saïd Business School Research Papers, July 2016), at https://eureka.sbs.ox.ac.uk/6195/1/2016-20.pdf.

177 B. Flyvbjerg, A. Stewart and A. Budzier, "The Oxford Olympics Study 2016: Cost and Cost Overrun at the Games" (University of Oxford, Saïd Business School Research Papers, July 2016), at https://eureka.sbs.ox.ac.uk/6195/1/2016-20.pdf.

178 Based on the most conservative estimates: see A. Zimbalist, Circus Maximus: the economic gamble behind hosting the Olympics and the World Cup, 2nd edn (Washington, D.C.: Brookings Institution Press, 2016), p.118; and for the cost information see National Audit Office, The London 2012 Olympic Games and Paralympic Games: post-Games review, Report by the Comptroller and Auditor General, HC 794, Session 2012-13, 5 December 2012 (London: The Stationery Office, 2012), at https://www.nao.org.uk/wpcontent/uploads/2012/12/1213794fr.pdf; K. Carpenter, "Preventing corruption ahead of major sports events: learning from the 2012 London Games", in Transparency International, Global Corruption Report: Sport (Abingdon: Routledge, 2016), Ch.3.9, pp.178-182, available via https://www.transparency.org/whatwedo/publication/global_corruption_report_sport.

179 B. Flyvbjerg, A. Stewart and A. Budzier, "The Oxford Olympics Study 2016: Cost and Cost Overrun at the Games" (University of Oxford, Saïd Business School Research Papers, July 2016), at https://eureka.sbs.ox.ac.uk/6195/1/2016-20.pdf.

180 B. Flyvbjerg, A. Stewart and A. Budzier, "The Oxford Olympics Study 2016: Cost and Cost Overrun at the Games" (University of Oxford, Saïd Business School Research Papers, July 2016), at https://eureka.sbs.ox.ac.uk/6195/1/2016-20.pdf.

${ }^{181}$ D. Von Plessen, The procurement strategies for the Olympic Stadium and the Aquatic Centre for the London 2012 Olympic Games (Hamburg: Anchor Academic Publishing, 2015), p.5.

${ }^{182}$ A. Zimbalist, Circus Maximus: the economic gamble behind hosting the Olympics and the World Cup, 2nd edn (Washington, D.C.: Brookings Institution Press, 2016), p.118.

183 [2015] Olympic Delivery Authority, "Report and Accounts" for the period April 1, 2014 to December 2, 2014, available at

https://assets.publishing.service.gov.uk/government/uploads/system/uploads/attachment_data/file/412429/0 DA_AR_2014_-_Web_PDF.pdf.

${ }_{184}$ [2015] Olympic Delivery Authority, "Report and Accounts" for the period April 1, 2014 to December 2, 2014, available at
} 
security services: the contracted services were extended significantly by agreement at a late stage, but the service provider then proved unable to supply the revised requirement, so that the armed forces and police were brought in for the work at the last minute ${ }^{185}$. The subsequent media coverage again highlighted the potential reputational risks of involvement with high profile events.) There was, however, criticism of the fact that the stadium design was not suited to the legacy use as a football stadium, resulting in a substantial public subsidy ${ }^{186}$.

London, like many other mega-events, fell sigificantly short of both the promise and post-event hype in terms of overall legacy ${ }^{187}$. However, it appears that integrity in the Games procurement itself was not a smajor problem and that the procurement experience left some positive legacy both for UK procurement and future events.

\subsection{Olympic and Paralympic Games, Rio de Janeiro, Brazil, 2016}

A reasonable amount of procurement information for Rio was found in 2018, most on official websites. Of particular importance were: the Transparency Portal for procurement ${ }^{188}$, which was adopted as part of Brazil's commitment to the Open Government Partnership launched in $2011^{189}$ and contains information on all public entities in Brazil, including information on public contracts such as tender documents, contracts, summary of amendments, price paid and completion date; the website of the Public Olympic Authority ${ }^{190}$ - a public consortium of the federal government, state and city hall of Rio de Janeiro ${ }^{191}$; the website of local implementing agency Riourbe Municipal Company for Urban Development ${ }^{192}$; and the official website with a Responsibility Matrix ${ }^{193}$ (which followed a 2014 World Cup initiative to provide to the public and Government information on projects and the responsibilities of different government bodies). The electronically available information was in theory quite comprehensive, including tender documents (although, as explained below, there was no e-procurement or even - from available evidence - electronic publication of solicitations). However, theory did not quite match practice and the information that was supposed to be there was often incomplete, unclear and disorganized, with not all

https://assets.publishing.service.gov.uk/government/uploads/system/uploads/attachment_data/file/412429/0 DA_AR_2014_-_Web_PDF.pdf.

185 National Audit Office, The London 2012 Olympic Games and Paralympic Games: post-Games review, Report by the Comptroller and Auditor General, HC 794, Session 2012-13, 5 December 2012 (London: The Stationery Office, 2012), at https://www.nao.org.uk/wp-content/uploads/2012/12/1213794fr.pdf.; K. Carpenter, "Preventing corruption ahead of major sports events: learning from the 2012 London Games", in Transparency International, Global Corruption Report: Sport (Abingdon: Routledge, 2016), Ch.3.9, pp.178-182, available via https://www.transparency.org/whatwedo/publication/global_corruption_report_sport.

${ }^{186}$ A. Zimbalist, Circus Maximus: the economic gamble behind hosting the Olympics and the World Cup, 2nd edn (Washington, D.C.: Brookings Institution Press, 2016), pp.119-120. There was a successful law suit voer 187 See e.g. J.R. Gold and M.M. Gold, "Framing the future: Sustainability, legacy and the 2012 London games" in R. Holt and D. Ruta (eds), Routledge Handbook of Sport and Legacy: Meeting the Challenge of Major Sports Events (London: Routledge, 2015), Ch.10, pp.142-158; P. Cohen and P. Watt (eds), London 2012 and The Post Olympic City: A Hollow Legacy? (London: Palgrave Macmillan, 2017); S. Wagg, The London Olympics of 2012: Politics, Promises and Legacy (London: Palgrave Macmillan, 2015); A. Zimbalist, Circus Maximus: the economic gamble behind hosting the Olympics and the World Cup, 2nd edn (Washington, D.C.: Brookings Institution Press, 2016), pp.114-125. There were some issues with the sustainability elements of the procurement programme (which, as noted, our mapping did not cover) although this was also successful in many respects: see, for example, J. Timms, "A socially responsible business legacy: raising standards in procurement, supply chains and employment at the London Olympics of 2012", in R. Holt and D. Ruta (eds), Routledge Handbook of Sport and Legacy: Meeting the Challenge of Major Sports Events (London: Routledge, 2015), Ch.15, pp.217-228.

188 http://portaltransparencia.gov.br. This Portal has changed in layout and information available. The procurement information for Rio Olympics once available in http://portaltransparencia.gov.br/rio2016/ (regarding tender documents, contracts, amendments), was apparently removed and hardly any can now be found.

${ }^{189}$ See https://www.opengovpartnership.org/.

${ }^{190}$ After the entity was wound up, the website (http://www.apo.gov.br/index.php/home/) was removed

191 Established by Federal Law no 12.396, of March 21, 2011.

192 http://www.rio.rj.gov.br/web/riourbe.

193 http://www.brasil2016.gov.br/pt-br/legado/matriz-de-responsabilidades. 
entities supplying the required information. For example, there was a tender for the Olympic Park of Barra of around 430 million USD with almost no documentation. There was also no publication of the number of bids submitted in public tenders, name of the bidders or any elements of the winning bid for any of the mapped procedures, information that was required to be collected by Article 38, IV and VII, of Federal Law n. 0 8666/93 and some of which (such as number of bids and name of bidders) was within the intended coverage of the Transparency Portal. Most of the mapped contracts were also financed with Federal resources, based on financial agreements that were not always available for consultation. Further, by 2019 the Transparency Portal ${ }^{194}$ had been modified, so that tender documents and contract amendments were no longer available and the Public Olympic Authority's website had been removed as a result of its being wound up. Some procurement information was also available in an "Instruction Manual" approved by legislation, which established certain mandatory rules on the conduct of public tenders and financial agreements ${ }^{195}$.

The Responsibility Matrix indicates 16 main projects for sport-related infrastructure, each including diverse infrastructure, in four geographical areas in Rio (Barra, Deodoro, Copacabana and Maracanã ${ }^{196}$ ), with both new infrastructure (for example, the Aquatics Centre and Olympic Handball Arena/Future Arena) and improvements (for example, the Stadium João Havelange). The mapping covered nine pieces of infrastructure (one mapped procurement for each ${ }^{197}$ ), namely the Tennis Centre, Olympic Handball Centre/Future Arena, Aquatics Centre, Velodrome, Olympic Sports Centre of Deodoro South (Equestrian Centre), Olympic Sports Centre of Deodoro North (Youth Arena, Stadium, Aquatic Centre, Hockey Centre, Shooting Park, Radical BMX Park), Olympic Stadium "João Havelange", Olympic Park of Barra (Arenas 1, 2 and 3), Main Press Centre, Press Hotel, Olympic and Paralympic Village), and Sambódromo. The selection was made with preference to the more valuable procurements and those for which there was a reasonable volume of official information. The Responsibility Matrix put the estimated price for sport-related infrastructure at around 2 billion USD ( 500 million USD from federal funds and investment in a public-private partnership of approximately 430 million USD ${ }^{198}$, with a residual 190 million USD from municipal funds) ${ }^{199}$ and the mapping covered $50 \%$ of this in value ${ }^{200}$.

Most procurements of both sport-related and other infrastructure were carried out by local public authorities with federal resources ${ }^{201}$. The other infrastructure used either a PPP model, or the state government as the implementing agency ${ }^{202}$. The body responsible for procuring seven of the pieces of mapped infrastructure was the Municipality of Rio de Janeiro, using RioUrbe - Municipal Company for Urban Development (a wholly owned company of the Municipality) to fulfil its tasks, whereas the other two pieces the Municipality procured directly. All these entities worked alongside the Public Olympic Authority ${ }^{203}$ to manage the implementation of the event. With the winding up of the Public Olympic Authority a new entity ${ }^{204}$ (Autoridade de Governança do Legado Olímpico - AGLO) was created to replace it and manage the legacy after the event was finished.

\footnotetext{
194 http://www.portaltransparencia.gov.br/programas-de-governo/19-olimpiadas?ano=2015.

195 "Instruction Manual for the Approval and Execution of the Programs and Actions of the Ministry of Sports included in the Growth Acceleration Program - PAC, aiming at the implementation of the necessary infrastructure for the holding of the Rio 2016 Olympic and Paralympic Games" (authors' translation) approved by Legal Act "Portaria" no 84/2013 of April 24, 2013:

www.esporte.gov.br/arquivos/institucional/.../manualInstrucoesPACSNEAR2.doc.

196 http://www.brasil2016.gov.br/pt-br/legado/matriz-de-responsabilidades.

197 No additional procurements could be found for any of this infrastructure.

198 http://www.brasil2016.gov.br/pt-br/legado/matriz-de-responsabilidades.

199 http://www.brasil2016.gov.br/pt-br/legado/matriz-de-responsabilidades.

200 http://www.brasil2016.gov.br/pt-br/legado/matriz-de-responsabilidades.

201 http://www.brasil2016.gov.br/pt-br/legado/matriz-de-responsabilidades.

202 http://www.brasil2016.gov.br/pt-br/legado/matriz-de-responsabilidades.

${ }^{203}$ As already mentioned, this entity was wound up and its official website removed.

204 http://aglo.gov.br/.
} 
Apart from the Olympic Park of Barra (a privately-financed PPP model for which tender documents were not public), all the mapped procurement followed Federal Law n. ${ }^{0}$ $8666 / 93$, with the method being simple Build, or Build and Operate ${ }^{205}$, by a single contractor $^{206}$, and was financed through federal resources.

There was no evidence available in the websites consulted of early market engagement and research for any of the mapped projects. There was also no information in the Transparency Portal, the Olympic Public Authority's website and the implementing agency's website on any risk assessments, value for money analysis, market analysis, feasibility study, demand analysis or supplier's engagement studies. It was not possible to find any post-event audit reports on procurement issues by the competent entities, such as the Account Court of the Union, despite the problems found in many procedures, such as reserve prices in tender documents exceeding the planned/budgeted amount: see below.

The primary source of the legal framework for public procurement is Federal Law $n .0$ $8666 / 93$, which in various respects did not reflect procurement standards in international instruments ${ }^{207}$ and was considered over-complex and a barrier to speedy procurement. The 2014 Brazil World Cup and Rio served as a catalyst for calls to modernise the rules and address integrity issues, and this led to a new regime, the Regime Diferenciado de Contratações Públicas (Differentiated Contracting Regime), approved by Law n. ${ }^{\circ}$ $12.462 / 2011$. This was initially adopted specifically for procurement for temporary events, contemplating the 2013 Confederations Cup, the World Cup and Rio, and works and services for airports ${ }^{208}$, as an experimental measure, and on an optional basis for procuring entities. The Law ${ }^{209}$ included new principles of efficiency, innovation, economy and sustainable development; stressed the need for a cost-benefit analysis ${ }^{210}$, including of social and environmental considerations, prior to the decision to procure; addressed e-procurement; included efficient qualification processes and other changes to speed up procurement; delimited the procedural stages more clearly; promoted integration of design and build elements; provided for the possibility of negotiating improved terms with the winning bidder; and provided the option of not disclosing the budget to, among other things, address bid-rigging ${ }^{211}$. This new, optional, regime, was not in fact used for any of our mapped procurements but was, however, used in some cases, such as for airport related works, and later was gradually extended to cover most major federal works ${ }^{212}$.

\footnotetext{
205 No references to ownership were found in the tender documents or contracts analysed.

${ }^{206}$ The available information was not sufficient to determine the extent of integration of design and build.

207 Examples include public solicitations merely being required to be posted at the headquarters of the public authority, absence of e-procurement and absence of provision for negotiation.

208 On the initial and later scope see D. Siqueira Borda and M. Gasparoto Tonin, "Differential Public Procurement Regime (RDC): Main Characteristics", in M.J. Filho, C. Pereira and M.A. Rost (eds), Brazil Infrastructure Law (The Hague: Eleven International Publishing, 2016), Ch.19, pp.299-318, s.19.4.

${ }^{209}$ See further D. Siqueira Borda and M. Gasparoto Tonin, "Differential Public Procurement Regime (RDC): Main Characteristics", in M.J. Filho, C. Pereira and M.A. Rost (eds), Brazil Infrastructure Law (The Hague: Eleven International Publishing, 2016), Ch.19, pp.299-318; A. Spalding and University of Richmond Law School AntiCorruption Team, "Olympic Anti-Corruption Report: Brazil and the 2016 Rio Games" (2017), at https://law.richmond.edu/olympics/archive-brazil.html; R. Monteiro Rezende "O regime diferenciado de contrataçoes públicas, comentarios à lei 12.462 de 2011" (The Differentiated Public Procurement Regime, Commentaries on the Law 12.462 of 2011; authors' translation) (Núcleo de Estudos e Pesquisas do Senado, 2011); M.J. Filho, Comentários ao RDC (Commentaries on the RDC; authors' translation) (São Paulo: Dialética, 2013); M.J. Filho, C.A. Guimarães Pereira (Orgs.), O Regime Diferenciado de Contratações Públicas (RDC) Comentários à Lei no 12.462 e ao Decreto no 7.581 (The Differentiated Public Procurement Regime, Commentaries on the Law 12.462 and on Decree n. ${ }^{\circ}$ 7.581; authors' translation), 3rd edn (Belo Horizonte: Fórum, 2014).

${ }^{210}$ Article 4.0, para. III, RDC.

${ }^{211} \mathrm{E}$. Berelsawki, A critical analysis of the procedures of the differentiated contracting regimen (RDC) of Brazil: the impact of the disclosure or not of the estimated budget and the use of the estimated budget as a ceiling and contract awarding factor, LL.M dissertation (University of Nottingham, School of Law, 2013).

${ }_{212}$ The RDC currently covers the procurement for actions included in the Growth Acceleration Program; works and engineering services under the Unified Health System (included in Law 12745, of December 19, 2012); works and engineering services for the construction, expansion, reform and administration of penal
} 
There has been some disagreement on the merits and constitutionality of the new regime ${ }^{213}$. The fact that it granted a wider margin of discretion to pursue efficient, innovative and sustainable procurement was perceived by some as a negative aspect and possible enhancer of illicit activities ${ }^{214}$; and Gaffney $^{215}$ argues that it causes debt problems as a result of municipal and state governments taking advantage of the situation to build on a massive scale in an accelerated time frame. This implies that this is an example of a problematic exemption from regular procurement rules for sport events rather than a positive development. However, lasting reforms from the new regime have been regarded by others as a positive legacy for Brazil's procurement system ${ }^{216}$ and a driving force for beneficial change in the overall public procurement regime in Brazil ${ }^{217}$.

Under Federal Law n. ${ }^{\circ} 8666 / 93$, which was used for our mapped projects, most of the infrastructure was procured using open public tenders without pre-qualification. Direct awards were available only in exceptional circumstances. They were used for two of the mapped procurements: the Handball Centre, on the grounds there were no bids in the open procedure ${ }^{218}$, and improvements in Sambódromo, on the grounds of emergency ${ }^{219}$. There was a general use of lowest price award criteria without even evidence in the tender documents or contracts of the detailed technical specifications or conditions, which may be considered problematic, as well as other problems including noncompliance with information obligations (see above). No evidence of e-procurement was found on any of the official websites for any of the mapped procurements; even the solicitations were posted at the headquarters of the procuring entity and/or published in the municipal diary/journal of Rio de Janeiro, with no evidence in the Transparency Portal or OPA website of wider publication at Federal level as required by law for federally-funded projects (paragraph 9.5. of Portaria n. 0 84/2013).

Numerous amendments were found, including price increases (for example, with the Velodrome) and changes to timescales. These were published but merely with a brief statement of the relevant legal provisions and the title of the amendment (the law requiring merely including a vague obligation to publish a "short version" of amendments ${ }^{220}$ ), without detail or reasons.

establishments and socio-educational assistance units (art. 1, VI, of Law n. ${ }^{0} 12462$, of August 4, 2011, on Differentiated Public Procurement Regime (RDC), amended by Law 13190, of November 19, 2015); works and engineering services related to improvements in urban mobility or expansion of logistics infrastructure (art. 1, VIII, of Law n. ${ }^{\circ}$ 12462, of August 4, 2011, on Differentiated Public Procurement Regime (RDC), amended by Law 13190, of November 19, 2015); contracts for the lease of movable and immovable property (art. 1, IX and 47-A of Law n. 0 12462, of August 4, 2011, on Differentiated Public Procurement Regime (RDC), amended by Law 13190, of November 19, 2015); actions in organs and entities dedicated to science, technology and innovation (art. 1, X, of Law n. ${ }^{12462}$, of August 4, 2011, on Differentiated Public Procurement Regime (RDC), amended by Law 13243, of January 11, 2016); and engineering works and services within the public systems of education and research, science and technology (art. 1, para. 3, of Law n. 0 12462, of August 4, 2011, on Differentiated Public Procurement Regime (RDC), amended by Law 13190, November 19, 2015). Some of its features have now been incorporated into the proposed new Public Procurement Law for Brazil in Bill 1292/95, which is expected to be adopted later this year (authors' translation).

${ }^{213}$ See R. Monteiro Rezende "O regime diferenciado de contrataçoes públicas, comentarios à lei 12.462 de 2011" (The Differentiated Public Procurement Regime, Commentaries on the Law 12.462 of 2011; authors' translation) (Núcleo de Estudos e Pesquisas do Senado, 2011), p.12.

${ }^{214}$ C. Mendes Bertoncini Corrêa and R. Zumblick Martins da Silva, "O regime diferenciado de contratações públicas e um novo panorama licitatório no Brasil" (The Differentiated Public Procurement Regime and a New Bidding Panorama in Brazil; authors' translation) (2016) 23:29 Revista da ESMESC 315, at p.336.

${ }^{215}$ C. Gaffney, "The Brazilian experience as 'role model'", in Transparency International, Global Corruption Report: Sport (Abingdon: Routledge, 2016), Ch.3.13, pp.204-210, available via https://www.transparency.org/whatwedo/publication/global_corruption_report_sport.

${ }_{216}$ A. Spalding and University of Richmond Law School Anti-Corruption Team, "Olympic Anti-Corruption Report: Brazil and the 2016 Rio Games" (2017), at https://law.richmond.edu/olympics/archive-brazil.html.

217 M.J. Filho, Comentários ao RDC (Commentaries on the RDC; authors' translation) (São Paulo: Dialética, 2013), p.15.

${ }_{218}$ Art. 24, 5 of Federal Law n. ${ }^{8} 8666 / 93$, of June 21, 1993 (on file with the authors).

${ }^{219}$ Art. 24, 4 of Federal Law n. ${ }^{\circ}$ 8666/93, of June 21, 1993.

220 Art. 61 of Federal Law n.0 8666/93, of June 21, 1993. 
As with other mega-events there were cost overruns at various points. For example, the reserve price defined in tender documents was higher than the planned/budgeted amount for some mapped procurements (Tennis Centre, Olympic Velodrome), with no formal justification published in the Transparency Portal or OPA website. However, the Oxford Olympics Study indicates that overrun overall from the event bid to final cost for the direct sport-related costs covered by the study appeared to be ${ }^{221}$, at $51 \%$, no higher than the median for Olympics since $1999^{222}$ and less than the London and Sochi $2014^{223}$, with a cost per athlete similar to previous Summer Games and substantially lower than London ${ }^{224}$. On the other hand, it became clear quickly after the Games that many of the plans for using infrastructure that could have justified some of the expenditure would not come to fruition, with the infrastructure being effectively abandoned and falling into disrepair ${ }^{225}$. There was also a struggle to complete all the infrastructure, including venue infrastructure, on time ${ }^{226}$ and it appears that some (including athletes' accommodation) was not ready to the required standard ${ }^{227}$; and as illustrated by Hayman's article in this issue there were some extreme cost-overruns on some of the broader infrastructure projects $^{228}$.

Corruption allegations over the infrastructure procurement have been made relating to five contractors (OAS, Odebrecht, Queiroz Galvão, Mendes Júnior and Camargo Correa) ${ }^{229}$. These are part of a bigger picture of alleged widespread corruption that is still being investigated as part of "Operation Car Wash", which commenced in March 2014 over allegations of bribery by construction firms of executives of Petrobras, the state oil company, but has spread much more widely and led to the arrest of many politicians and business persons (including the Governor and several lawmakers of Rio state ${ }^{230}$ ) and a lengthy jail sentence for former President Luiz Inacio Lula da Silva. Six of the 12 stadiums built for the 2014 Brazil World Cup have also been under investigation for irregularities and bribery ${ }^{231}$, as have alleged payments from politicians to the IOC in connection with the bid to host the Games ${ }^{232}$.

\footnotetext{
${ }^{221}$ The Games had not been competed at the time of the Oxford study and therefore only preliminary data could be used.

${ }^{222}$ After the Olympic Games Knowledge Management Program took effect.

${ }^{223}$ B. Flyvbjerg, A. Stewart and A. Budzier, "The Oxford Olympics Study 2016: Cost and Cost Overrun at the Games" (University of Oxford, Saïd Business School Research Papers, July 2016), at https://eureka.sbs.ox.ac.uk/6195/1/2016-20.pdf.

224 B. Flyvbjerg, A. Stewart and A. Budzier, "The Oxford Olympics Study 2016: Cost and Cost Overrun at the Games" (University of Oxford, Saïd Business School Research Papers, July 2016), at https://eureka.sbs.ox.ac.uk/6195/1/2016-20.pdf.

225 D. Burke, "Brazil's $\$ 12$ billion Olympic legacy lies in ruins: Five months after the Rio Games, stadiums are crumbling as cash-strapped nation is left with crippling debts", Mail Online, February 20, 2017, at https://www.dailymail.co.uk/news/article-4241412/Brazil-s-12-billion-Olympic-legacy-lies-ruins.html.

${ }^{226}$ On the pre-event delays see A. Zimbalist, Circus Maximus: the economic gamble behind hosting the Olympics and the World Cup, 2nd edn (Washington, D.C.: Brookings Institution Press, 2016), pp.108-110.

227 T. Lewis, "Rio 2016: five Olympic stories to take your breath away", The Guardian, July 31, 2016, at https://www.theguardian.com/sport/2016/jul/30/five-stars-to-watch-at-rio-olympics.

${ }^{228}$ G. Hayman, "Better procurement for major sporting events: will we see open contracting for Paris 2024?" (2019) 28 P.P.L.R. $x x x$.

${ }^{229}$ V. Konchinski and V. Segalla, "Operação Lava Jato ameaça 73\% das obras da Olimpíada de 2016", UOL Esporte, November 21, 2014, at https://esporte.uol.com.br/rio-2016/ultimas-noticias/2014/11/21/operacaolava-jato-ameaca-73-das-obras-da-olimpiada-de-2016.htm; P. Stauffer, "Há mais projetos ligados a Rio 2016 sob investigação do que revelado, diz procurador da Lava Jato", Reuters, April 19, 2016, at https://br.reuters.com/article/businessNews/idBRKCNOXG2GY. And see also e.g. J. Chade, "Stadium deals, corruption and bribery: the questions at the heart of Brazil's Olympic and World Cup 'miracle'", The Guardian, April 23, 2017, at https://www.theguardian.com/sport/2017/apr/23/brazil-olympic-world-cup-corruptionbribery.

230 "Rio governor Pezão arrested on corruption charges", BBC News, November 29, 2018, at https://www.bbc.co.uk/news/world-latin-america-

46384397?intlink_from_url=https://www.bbc.co.uk/news/topics/cr08zpj6lk0t/operation-carwash\&link_location=live-reporting-story.

231 J. Chade, "Stadium deals, corruption and bribery: the questions at the heart of Brazil's Olympic and World Cup 'miracle'", The Guardian, April 23, 2017, at https://www.theguardian.com/sport/2017/apr/23/brazilolympic-world-cup-corruption-bribery.

${ }^{232}$ Rio Olympic chief arrested in connection with bribery to get the Games - see M. Kelner, "Rio 2016 Olympic chief Carlos Nuzman arrested in corruption investigation", The Guardian, October 5, 2017, at
} 
The Differentiated Contracting Regime referred to earlier was just one of four new laws enacted in the run-up to the 2014 World Cup and 2016 Olympics following public protest, the others being Law No. 12.527/2011 on access to information requiring proactive publication of certain procurement information as well as provision of further information on request; a 2013 Anti-Corruption law which, among other things, provides a more extensive scope for bribery and creates a wide corporate liability; and a 2013 law giving enforcement powers to prosecutors ${ }^{233}$. Spalding et al have described these as together providing an "Olympic governance legacy" that have "fundamentally reshaped Brazilian anti-corruption enforcement in ways that will endure long after the 2016 Olympics have ended"234. They argue that discovery of, and action on, corruption should be viewed more as a success than a failure of integrity policy, given that without the reforms, for which the mega-events served as a catalyst, corrupt behaviour would simply have remained hidden ${ }^{235}$.

\subsection{Winter Olympic and Paralympic Games, Vancouver, Canada}

Very little information was available on Vancouver, probably reflecting the length of time since the event, the fact that e-procurement was then in its infancy and the dissolution in 2014 of the Vancouver Organizing Committee for the 2010 Olympic and Paralympic Winter Games (VANOC), the main procuring entity. The main information sources were reports by VANOC and British Columbia's official website for procurement notices. However, not all notices for the venues were published/found and the accessible documents were limited to solicitations, the remainder of the procedures being paperbased. No master procurement plan or programme was found, or even the bid for hosting the event that would indicate the extent of infrastructure procurement. The projects examined were a small number that both appeared important and for which at least minimal, although limited, information was available: the Nordic Competition venue drilling works and Whistler Sliding Center ${ }^{236}$, a procedure in lots covering site preparation, roads and utilities, track, refrigeration plant and building, and other building and civil works. The tenders were not found online. ${ }^{237}$

As noted, the main procuring entity for infrastructure was VANOC, a non-profit organisation with the status of a public authority ${ }^{238}$ created for the event, which dissolved in $2014^{239}$.

No information on the pre-tendering phase was found online. However, as regards risk management, one report indicates that VANOC put in place a comprehensive risk

https://www.theguardian.com/world/2017/oct/05/brazilian-police-arrest-olympics-chief-carlos-arthur-nuzmanbribery-investigation.

${ }^{233}$ See A. Spalding and University of Richmond Law School Anti-Corruption Team, "Olympic Anti-Corruption Report: Brazil and the 2016 Rio Games" (2017), at https://law.richmond.edu/olympics/archive-brazil.html, Ch.4; L.B. Arrieta, "Taking the Jeitinho out of Brazilian Procurement: The Impact of Brazil's Anti-Bribery Law" (2014) 44 Public Contract Law Journal 157.

${ }^{234}$ A. Spalding and University of Richmond Law School Anti-Corruption Team, "Olympic Anti-Corruption Report: Brazil and the 2016 Rio Games" (2017), at https://law.richmond.edu/olympics/archive-brazil.html, Ch.4.

${ }^{235}$ A. Spalding and University of Richmond Law School Anti-Corruption Team, "Olympic Anti-Corruption Report: Brazil and the 2016 Rio Games" (2017), at https://law.richmond.edu/olympics/archive-brazil.html, Ch.4.

${ }^{236}$ Other notices found related only to goods and services or small infrastructure procurements, such as a notice relating to the Nordic Competition venue.

${ }_{237}$ The procurement notices were accessed via the British Columbia procurement website: https://www.bcbid.gov.bc.ca/open.dll/welcome?lamguage=En.

238 Under the Canada Corporations Act (Canada Business Corporations Act (R.S.C., 1985, c. C-44)). VANOC was guided by a 20-member board of directors nominated by the Government of Canada, the Province of British Columbia, the City of Vancouver, the Resort Municipality of Whistler, the Canadian Olympic Committee, the Canadian Paralympic Committee and the Squamish and Lil'wat First Nations. It reported to the Canadian Olympic Committee and IOC: see https://searcharchives.vancouver.ca/vancouver-organizing-committee-for2010-olympic-and-paralympic-winter-games.

${ }^{239}$ See "VANOC breaks even, to be dissolved 4 years after 2010 Winter Games", Daily Hive, July 3, 2014, at http://dailyhive.com/vancouver/vanoc-breaks-even-dissolved-4-years-2010-olympic-winter-games/. 
assessment system, including appointing a Vice President of Risk Management, and indicated also frequent meetings with the construction team and risk management activities at the planning stage $\mathrm{e}^{240}$.

As for procurement procedures, according, to the Games Audit: "In October 2003, VANOC's Audit and Finance Committee established interim policies and procedures such as Delegation of Financial Authorities and Interim Procurement Procedures which were inspired by the policies used by the Province of British Columbia until the Committee developed a full and detailed set of Policies. Most of the policies were finalized in 2006". ${ }^{241}$ Policies on procurement procedures were not found online and the relationship with relevant legislation is unclear but the solicitations indicate that open public tenders, which in one case included pre-qualification ${ }^{242}$, were used for the mapped procurements.

VANOC was responsible for contract execution as well as award, and for the Whistler Sliding Centre appointed a private party (Stantec Architecture Ltd) to manage the design and construction. There is, however, no information online on the structures for, or existence of, contract amendments.

The Games as a whole broke even ${ }^{243}$. According to the Oxford Olympics Study, covering sport-related infrastructure, the event also had the lowest cost overruns between bidding for the event and completion of any Winter Olympics at only 13\% (lower than for most types of major infrastructure), and a cost per athlete around the median for all Winter Olympics and the lowest (just) of the four in the current millennium ${ }^{244}$. No allegations of integrity problems were found, the main controversy reported being the limited use of French. ${ }^{245}$

\subsection{Winter Olympic and Paralympic Games, Sochi, Russia, 2014}

Sochi was perceived by some as aiming primarily to promote Russia, put Sochi on the map, and bolster internal support - a "nationalist" rather than "commercial" narrative ${ }^{246}$. Indeed, it has been suggested that mega-events in Russia even serve to "provide corruption opportunities that facilitate the informal networks needed to keep the system running" ${ }^{247}$, offering incentives to support the regime by distribution of benefits and also a degree of control over business; and that corruption leaks and measures represent jockeying for position within the ruling elites rather than serious attempts to address corruption ${ }^{248}$. Some of these perspectives are also relevant for other events, but have been particularly examined in relation to Sochi ${ }^{249}$, and analysis of the approach to

\footnotetext{
240 See "Audit of the Vancouver Organizing Committee (VANOC) for the 2010 Olympic and Paralympic Winter Games: Contributions Agreements" (Canadian Heritage, Assurance Services Directorate, Corporate Review Branch, October 2007), at http://publications.gc.ca/collections/collection_2014/pc-ch/CH6-18-2007-eng.pdf. ${ }^{241}$ See "Audit of the Vancouver Organizing Committee (VANOC) for the 2010 Olympic and Paralympic Winter Games: Contributions Agreements" (Canadian Heritage, Assurance Services Directorate, Corporate Review Branch, October 2007), at http://publications.gc.ca/collections/collection_2014/pc-ch/CH6-18-2007-eng.pdf. ${ }^{242}$ Here VANOC reserved the right to limit the number of pre-qualified suppliers invited (that is, to operate a reduction in numbers process) but no further details were found.

${ }^{243}$ See "Vancouver 2010 Winter Olympics debt-free, VANOC final report says", CBC News, July 3, 2014, at http://www.cbc.ca/news/canada/british-columbia/vancouver-2010-winter-olympics-debt-free-vanoc-finalreport-says-1.2695994.

${ }^{244}$ B. Flyvbjerg, A. Stewart and A. Budzier, "The Oxford Olympics Study 2016: Cost and Cost Overrun at the Games" (University of Oxford, Saïd Business School Research Papers, July 2016), at https://eureka.sbs.ox.ac.uk/6195/1/2016-20.pdf.

245 See Office of the Commissioner of Official Languages, Raising Our Game for Vancouver 2010: Final Report on the Vancouver 2010 Olympic and Paralympic Winter Games (December 2010), at http://www.officiallanguages.gc.ca/sites/default/files/stu_etu_games_jeux_e_02_2011.pdf.

246 See, for example, R.W. Orttung and S. Zhemukhov, "The 2014 Sochi Olympic mega-project and Russia's political economy" (2014) 30 East European Politics 175, at p.177.

${ }^{247}$ R.W. Orttung and S. Zhemukhov, "The 2014 Sochi Olympic mega-project and Russia's political economy" (2014) 30 East European Politics 175, at p.176.

248 See R.W. Orttung and S. Zhemukhov, "The 2014 Sochi Olympic mega-project and Russia's political economy" (2014) 30 East European Politics 175, at p.185.

${ }_{249}$ See the literature in the notes to this article.
} 
integrity risk clearly needs to take account of these perspectives, rather than to assume that a corruption-free event is the national objective. As explained below, the costs of Sochi escalated way beyond what is usual even for mega-events, with many (although unproven) allegations of corruption and fraud.

Information and documentation for some infrastructure procurement was available online. Information on individual procurements was found in the Russian e-procurement system for some procurements of OlymStroy, a state corporation funded by the federal budget and subject to federal oversight, which had main responsibility for infrastructure procurement. This extensive documentation included solicitations, specifications, qualification criteria, breakdown of estimated price, time schedules, contract templates, information on lots and evaluation commission reports. However, there was limited information on procurement of the venues and other sport-related projects (as opposed to other projects) of OlymStroy, and on projects by other entities. According to the initial Programme ${ }^{250}$, other entities involved included Krasnaya Polyana (a publicly owned joined stock company) and Company for the Development of Mountain Ski Resort "Rosa Khutor" (a limited liability company); but the Russian e-procurement system contained procurement material only from OlymStroy ${ }^{251}$, presumably because limited liability companies were outside public procurement rules. Further, OlymStroy's official website is archived and was accessible only with limitations ${ }^{252}$, precluding access to the pages containing procurement notices and documentation ${ }^{253}$, although the event Programme and procurement policies were still found. It has been reported that OlymStroy refused to publish its specific project costs ${ }^{254}$. Limited use of electronic means, with tenders generally being paper-based, also limited the documentation available, as tenders were not published.

This event involved procurement of both sport-related infrastructure and other infrastructure such as transport, power and sewage treatment, the latter accounting for $80 \%$, and directed at regeneration and at promoting Sochi as a prominent resort ${ }^{255}$. OlymStroy was set up as a state corporation in 2007 specifically for organising the Games ${ }^{256}$, and was the main entity undertaking the venue procurement - which included 11 stadia (ten new) in two clusters, mostly procured by OlymStroy ${ }^{257}$ - and other siterelated procurement. OlymStroy also undertook other infrastructure procurement, including for roads, some of which we mapped, as discussed below. It has been suggested that OlymStroy was allocated responsibilities to limit transparency, as such a state corporation is subject to less transparency than both public entities and the Organising Committee for the Olympic Games (OCOG), the latter being accountable to the International Olympic Committee ${ }^{258}$; and consideration of the model of a bespoke entity as a vehicle for delivering event infrastructure may need to take into account the

\footnotetext{
250 Decision of the Government of the Russian Federation N 991 of December 29, 2007, "On the Program on the Construction of Olympic Venues and Development of the city of Sochi as a Mountain Climatic Resort" (authors' translation from Russian).

251 The procurement documents were accessed through the single point of access: http://zakupki.gov.ru/epz/main/public/home.html.

252 See https://web.archive.org/web/20130323101853/http://sc-os.ru/ru/about/.

${ }^{253}$ It cannot be seen exactly what information was formerly available on the site for the various procurements.

254 A. Foxall, Russia's Olympic Shame: Corruption, Human Rights and Security at 'Sochi 2014' (London: The Henry Jackson Society, 2014), pp.4-6. For costs of the stadia and other key infrastructure, taken from the media, see pp.8-10.

255 O. Gulubchikov, "The Sochi Winter Olympics: Who stands to gain?", in Transparency International, Global Corruption Report: Sport (Abingdon: Routledge, 2016), Ch.3.10, pp.183-191 at pp.183-184, available via https://www.transparency.org/whatwedo/publication/global_corruption_report_sport.

${ }^{256}$ See Federal Law N 238-FZ of October 30, 2007, "On State Corporation for the Construction of Olympic Venues and the development of the city of Sochi as a mountain climatic resort" (authors' translation from Russian).

257 Some was undertaken by other entities e.g. the design and build for the complex of ski jumps K-125, K-95 by OJSC Krasnaya Polyana and the design and built of a small ice arena by a limited liability company UGMK Holding.

${ }^{258}$ R.W. Orttung and S. Zhemukhov, "The 2014 Sochi Olympic mega-project and Russia's political economy" (2014) 30 East European Politics 175, at pp.183-185.
} 
difference in the contexts for creating OlymStroy, on the one hand, and the bespoke bodies for London and Vancouver, on the other. As noted, other types of entities also undertook infrastructure procurement at Sochi. This included some venue procurement, as already mentioned; the main gas and electricity works and services, which were entrusted to existing monopolists in the form of state corporations (for example, gas pipes and automatic gas allocation stations to Gazprom, railway works to Russian Railway Roads and roads to the Federal Transport Agency); and procurement for the Main Olympic village, which was entrusted to a limited liability company, RogSibAl. Construction of hotel accommodation was made the responsibility of those hotels by mentioning them in the event Programme.

Three projects were chosen for mapping on the basis that they were significant and that some information was available, all undertaken by OlymStroy. These were the project for security support facilities for venues and infrastructure for the Mountain Cluster (3.3 billion USD); a sewage pumping station ( 3 million USD); and certain renovation works for municipal roads. As noted, no significant information was available for the main venue procurement.

Both the two new construction projects were done on a Design and Build basis, each with a single contractor. For the Games generally there was an initial attempt to leverage private financing, in particular from oligarchs, for infrastructure such as hotels and roads, aiming to cover over half the Games' cost; but in the end this apparently counted for less than $10^{259}$. There is no indication of use of private finance for the mapped projects.'

No documents on market research were located for the mapped procurement (and is often not done in Russia); nor was there evidence of feasibility studies, impact assessment or systematic risk management. It has been suggested that poor planning in investigations and specification design contributed to the significant cost overruns. ${ }^{260}$ However, a Programme for the Construction of Olympic Venues and the Development of the city of Sochi as a Mountain Climate Resort ${ }^{261}$, amended in $2010^{262}$, set out planned construction activities and responsible authorities (although it can be noted that some of the mapped projects were not actually referred to there).

The general national legislation on public procurement did not apply to OlymStroy; its procurement was governed by the more flexible Law $223-\mathrm{FZ}^{263}$ adopted specifically for state corporations, natural monopolies and certain other quasi-public bodies, reflecting the generally limited transparency requirements for such bodies. This Law does not require specific procurement methods but just adherence to general principles such as transparency, equal participation and value for money and (in Art. 3(2)) a requirement to publish a notice no later than 20 days before a bid deadline. Complaints are investigated by the Federal Antimonopoly Agency. OlymStroy itself, however, adopted documents to govern its procurement, and its General Rules on the Selection of Investors, Contractors for the Construction of Olympic Venues (2011) prescribe three

259 A. Foxall, Russia's Olympic Shame: Corruption, Human Rights and Security at 'Sochi 2014' (London: The Henry Jackson Society, 2014), pp.4-6; A. Zimbalist, Circus Maximus: the economic gamble behind hosting the Olympics and the World Cup, 2nd edn (Washington, D.C.: Brookings Institution Press, 2016), pp.84-86. Breakdown of the costs for selected Olympic venues can be found in "Sochi 2014: Encyclopaedia of Spending", at http://sochi.fbk.info/en/.

260 O. Gulubchikov, "The Sochi Winter Olympics: Who stands to gain?", in Transparency International, Global Corruption Report: Sport (Abingdon: Routledge, 2016), Ch.3.10, pp.183-191 at p.185, available via https://www.transparency.org/whatwedo/publication/global_corruption_report_sport.

261 See Decision of the Government of the Russian Federation N 991 of December 29, 2007, "On the Program on the Construction of Olympic Venues and Development of the city of Sochi as a Mountain Climatic Resort" (authors' translation from Russian).

262 See Government Decision N 57 of February 5, 2010, "On amending the Program on the Construction of Olympic Venues and Development of the city of Sochi as a Mountain Climatic Resort" (authors' translation from Russian).

${ }^{263}$ See Federal Law N 223-FZ of July 11, 2011, "On Procurement of Goods, Services, Works by certain types of legal entities" (authors' translation from Russian). 
procurement methods, tender, auction and competitive negotiations, all of which are open public tenders within our study definition. Auction was used for one of the mapped procurement and competitive negotiations, in which negotiations were conducted with suppliers, for the other two. The national procurement legislation also did not apply to much of the other infrastructure procurement which, as noted, was undertaken either by other entities subject to Law $223-\mathrm{FZ}$ or by limited liability companies outside procurement laws altogether. As mentioned, various notices were published electronically but bid submission was paper-based.

As regards contract execution, OlymStroy was required to submit annual accountancy and statistical reports to the President and Government of Russia ${ }^{264}$, report on the construction in the plan and subject annual financial reports to an audit by an organisation chosen by the Supervisory Board. Physical and financial progress was also reported with the exact amount of allocated and spent money for the given period and dates of the major stages of the construction process together with information on progress ${ }^{265}$. An internal commission controlled financial and economic activities of the OlymStroy and external audit was supposed to be carried out by the Accounts Chamber of Russia; however, our research was able to find only limited analysis by the latter ${ }^{266}$ and no full audit report. There was no information on exact governance mechanisms to control amendments, or on amendments made to the mapped projects.

The Oxford Olympics Study found Sochi to have the highest sport-related costs, at USD 21.9 billion, of any Games in history (Summer or Winter), with a cost per athlete more than four times that of the next most expensive Winter Games ${ }^{267}$; and the cost of specific types of projects, such as roads, was significantly higher than comparable projects outside Russia ${ }^{268}$. The Oxford Olympics Study put the cost overruns from bid to completion for the sporting infrastructure at $289 \%$, easily the greatest of the nine post199 Games (with a median of $51 \%$ and a mean average -significantly affected by Sochi itself - of 75\%). The Anti-Corruption Foundation, established in 2011 by Aleksey Navalny and funded by private donations, reported that certain contractors had friendly relations with Putin and some were selected using non-transparent procedures ${ }^{269}$ (although it has also been suggested that this merely "reflects the objective reality of corporate capacity to undertake large-scale projects given the oligarchic structure of Russia's economy ${ }^{\prime 270}$ ). In another report, however, Navalny points to actual corruption and collusion in procurement ${ }^{271}$ and other opposition figures have suggested that this

\footnotetext{
${ }^{264}$ Federal Law N 238-FZ of October 30, 2007, "On State Corporation for the Construction of Olympic Venues and the development of the city of Sochi as a mountain climatic resort" (authors' translation from Russian).

${ }^{265}$ See Report on the construction of Olympic venues and implementation of other activities related to the construction of Olympic venues for the year 2012 (authors' translation from Russian), at https://web.archive.org/web/20140207042205/http:/www.scos.ru:80/common/upload/otchet_2012/form_14.pdf.

${ }^{266}$ See Accounts Chamber of the Russian Federation, "Analysis of the measures undertaken for the elimination of irregularities in the preparation and realisation of XXII Winter Olympic and XI Winter Paralympic Games in Sochi in 2014" (authors' translation from Russian; Russian content), at http://www.ach.gov.ru/press_center/news/21280?sphrase_id=7349935.

267 B. Flyvbjerg, A. Stewart and A. Budzier, "The Oxford Olympics Study 2016: Cost and Cost Overrun at the Games" (University of Oxford, Saïd Business School Research Papers, July 2016), at https://eureka.sbs.ox.ac.uk/6195/1/2016-20.pdf.

${ }^{268}$ As reported by See R.W. Orttung and S. Zhemukhov, "The 2014 Sochi Olympic mega-project and Russia's political economy" (2014) 30 East European Politics 175, at p.183.

269 See also R.W. Orttung, "Olimpstroy: Building the Sochi Olympics from Scratch" (2014) 143 Russian Analytical Digest 5.

270 O. Gulubchikov, "The Sochi Winter Olympics: Who stands to gain?", in Transparency International, Global Corruption Report: Sport (Abingdon: Routledge, 2016), Ch.3.10, pp.183-191 at p.188, available via https://www.transparency.org/whatwedo/publication/global_corruption_report_sport.

271 See B. Nemtsov and L. Martynyuk, "Winter Olympics in the Subtropics" (Moscow: 2013), at https://www.putin-itogi.ru/winter-olympics-in-the-subtropics/ (translation by Kerkko Paananen):

https://www.putin-itogi.ru/cp/wp-content/uploads/2013/05/ZimniayaOlimpiadaVSubtropikah-Nemtsov-

Martyniuk.pdf); and see generally A. Foxall, Russia's Olympic Shame: Corruption, Human Rights and Security at 'Sochi 2014' (London: The Henry Jackson Society, 2014).
} 
accounts for more than $50 \%$ of the Games bill 272 . It has, indeed, been argued that the role of the Games in providing benefits to the elite from corruption to maintain support for the regime, combined with lack of democratic accountability and financial oversight, provides the main explanation of cost overruns ${ }^{273}$. Where legal proceedings were initiated - including relating to matters such as misuse of power during construction and signing of false labour contracts ${ }^{274}$ - either these were closed for absence of evidence ${ }^{275}$ or information on outcomes is not available ${ }^{276}$.

Many cases relating to the concluded contracts were brought in the Court of Arbitration both by and against OlymStroy, and after OlymStroy's liquidation suppliers were unable to maintain claims (an attempt by one to stop the liquidation was rejected) ${ }^{277}$ and several went bankrupt ${ }^{278}$. After liquidation OlymStroy also stopped claiming money itself. ${ }^{279}$ The Accounts Chamber ${ }^{280}$ instructed several entities to eradicate certain irregularities, including in procurement. ${ }^{281}$ It also mentioned that some venues were commissioned late, with late transfer to municipal and state ownership; that the Krasnodar region failed to finish five projects concerning matters such as sewage treatment and landfill with the Programme timescale ${ }^{282}$; and that hotel construction also suffered from late and inadequate completion ${ }^{283}$.

\subsection{World Games, Wrocław, Poland, 2017}

There was a limited amount of procurement information available online for this event. The general information on a bespoke web page $^{284}$ included information about the

272 B. Nemtsov and L. Martynyuk, "Winter Olympics in the sub-tropics", (2013), p.3, at

https://www.putin-itogi.ru/cp/wp-content/uploads/2013/05/ZimniayaOlimpiadaVSubtropikah-Nemtsov-

Martyniuk.pdf.

${ }^{273}$ R.W. Orttung and S. Zhemukhov, "The 2014 Sochi Olympic mega-project and Russia's political economy" (2014) 30 East European Politics 175.

274 See R.W. Orttung and S. Zhemukhov, "The 2014 Sochi Olympic mega-project and Russia's political economy" (2014) 30 East European Politics 175, at p.185, referring to a report of 46 cases initiated by Russia's Investigative Committee that did not, however, result in any trial; and the announcement by investigators "The investigators announced about corruption in OlymStroy worth $25 \mathrm{~m}$ roubles after the resignation of Balloev" (authors' translation from Russian), in Gazeta, January 31, 2011, at https://www.gazeta.ru/news/business/2011/01/31/n_1682318.shtml?updated.

275 See "OlymStroy" in RuCompromat: Encyclopaedia of the compromising materials' library, at http://rucompromat.com/organizations/olimpstroy (authors' translation from Russian).

276 O. Gulubchikov, "The Sochi Winter Olympics: Who stands to gain?", in Transparency International, Global Corruption Report: Sport (Abingdon: Routledge, 2016), Ch.3.10, pp.183-191 at p.188, available via https://www.transparency.org/whatwedo/publication/global_corruption_report_sport.

277 See Y. Vinogradova, "'OlymStroy' is dying but is not conceding: How liquidated state corporation continues claiming debts from the suppliers", Vedomosti, May 25, 2015, at https://www.vedomosti.ru/realty/articles/2015/05/25/593389-itogi-olimpiiskih-stroek (authors' translation from Russian; article content in Russian).

278 See S. Starikov and T. Dzyadko "'OlymStroy' owes about 6 billion RUB to contractors", RBC, October 21, 2014, at https://www.rbc.ru/business/21/10/2014/54450d18cbb20f2ce4aa042f (authors' translation from Russian; article content in Russian).

279 See Y. Vinogradova, "'OlymStroy' is dying but is not conceding: How liquidated state corporation continues claiming debts from the suppliers", Vedomosti, May 25, 2015, at https://www.vedomosti.ru/realty/articles/2015/05/25/593389-itogi-olimpiiskih-stroek (authors' translation from Russian; article content in Russian).

280 See L. Chizhova, "'OlymStroy' and Corruption", Svoboda, January 17, 2012, at https://www.svoboda.org/a/24454085.html (authors' translation from Russian; article content in Russian).

${ }^{281}$ See Accounts Chamber of the Russian Federation, "Analysis of the measures undertaken for the elimination of irregularities in the preparation and realisation of XXII Winter Olympic and XI Winter Paralympic Games in Sochi in 2014" (Accounts Chamber of the Russian Federation, April 10, 2015), at http://www.ach.gov.ru/press_center/news/21280?sphrase_id=7349935 (authors' translation from Russian; analysis content in Russian).

${ }^{282}$ See Accounts Chamber of the Russian Federation, "Analysis of the measures undertaken for the elimination of irregularities in the preparation and realisation of XXII Winter Olympic and XI Winter Paralympic Games in Sochi in 2014", (Accounts Chamber of the Russian Federation, April 10, 2015), http://www.ach.gov.ru/press_center/news/21280?sphrase_id=7349935 (authors' translation from Russian analysis content in Russian).

${ }^{283}$ A. Zimbalist, Circus Maximus: the economic gamble behind hosting the Olympics and the World Cup, 2nd edn (Washington, D.C.: Brookings Institution Press, 2016), p.89.

284 https://theworldgames2017.com/ (still accessible). 
infrastructure, while the main source of information on the procurement was the City of Wrocław web page 285 , linking to a page that included documentation such as solicitations and specifications ${ }^{286}$. The largest procurements were advertised in the Supplement to the Official Journal of the European Union (OJEU S) ${ }^{287}$ and as well as the City web page ${ }^{288}$. Pre-event reports in local media information included information matters such as the second Olympic Stadium renovation procurement (see below) ${ }^{289}$ and infrastructure costs ${ }^{290}$.

The study mapped the event's two main venue projects: renovation of the Olympic Stadium of 1928 (USD 25770 000) and renovation of a swimming pool complex (USD 14350 000). These were procured by Wrocławskie Inwestycje (Wroclaw Investment), a limited liability company with $100 \%$ municipal ownership ${ }^{291}$.

Both the stadium and pool were done by the method of Design and Build by a single contractor. Both were financed directly through Wrocławskie Inwestycje from the municipal budget, with co-financing from the Ministry of Sport and Tourism but no private finance.

Little public information was available on planning activities - although, there was some market analysis - or risk management; and nor could information be found on amendments or other matters relating to contract execution.

As regards award procedures, public procurement in Poland is regulated by the Act of 29 January 2004 - Public Procurement Law ${ }^{292}$, which transposes the main EU procurement directives 293 . This provides for various award procedures, including some allowing dialogue (for example, the EU's competitive dialogue procedure could have been used), but the mapped procurements used the open procedure, a type of open public tender allowing any party to bid in a single-stage tendering procedure without negotiations or pre-qualification. Other than publication of electronic solicitations and other notices as required by law, the processes, including contract documents, were paper-based, (although full electronic procurement has since become mandatory as required by EU law from 2018).

Despite market analysis, budget increases became necessary: the largest procedures were both annulled because each received just one bid which exceeded not only the project budgets - the bid for the stadium was double the budget - but Wroclaw's entire budget for the sporting infrastructure. This resulted in delay to both renovations (the pool project being amended significantly and tendered in two parts the second time

\footnotetext{
285 https://www.wroclaw.pl/przetargi-twg-2017

${ }^{286}$ Formerly at http://bip.theworldgames2017.com/ but no longer accessible.

287 See http://ted.europa.eu.

288 https://www.wroclaw.pl/przetargi-twg-2017

289 "Wrocław: Rusza drugi przetarg na Olimpijski" (Wrocław: The second tender for the Olympic is starting; authors' translation), Stadiony.net, May 14, 2014, source available in Polish at http://stadiony.net/aktualnosci/2014/05/wroclaw_rusza_drugi_przetarg_na_olimpijski.

290 M. Leśnik, "World Games 2017 w liczbach i pieniądzach" (World Games 2017 in numbers and money'; authors' translation), Wroclife, July 19, 2017, source available in Polish at https://wroclife.pl/czas-wolny/theworld-games-2017-wroclaw-otwarcie-bilety-koszty/.

${ }^{291}$ Wrocławski Komitet Organizacyjny - Światowe Igrzyska Sportowe 2017 Spółka z ograniczona odpowiedzialnością (Wrocław Organizing Committee - World Sports Games 2017), set up specifically for the event also with $100 \%$ municipal ownership, acted on behalf of the city authorities, especially in procurement connected with the organisation of the event, such as procurement of legal services. Other major procurements included organisation of hotel services (accommodation and catering) for athletes and officials, and tournament markings.

292 Journal of Laws of 2018 item 1986 with changes.

293 Directive 2014/24/EU of the European Parliament and of the Council of 26 February 2014 on public procurement and repealing Directive 2004/18/EC [2014] OJ L 94/65 (Public Contracts Directive); and Directive 2014/25/EU of the European Parliament and of the Council of 26 February 2014 on procurement by entities operating in the water, energy, transport and postal services sectors and repealing Directive 2004/17/EC [2014] O] L 94/243.
} 
around) but both were still completed just in time in time for the Games ${ }^{294}$. Several other legal challenges were also made, including one relating to compliance of bids with the specification in the second award procedure for the stadium and some relating to services contracts ${ }^{295}$.

The external audit entities that provide ongoing oversight for public procurement are the Central Anti-Corruption Bureau ${ }^{296}$, Supreme Audit Office ${ }^{297}$ and Regional Chamber of Accounts in Wrocław ${ }^{298}$. However, there was no information on any corruption problems during execution. Overall the event was considered a success ${ }^{299}$ and was awarded the "Event of the Year" title in the national Polish Radio Sport Awards.

\subsection{Youth Olympics, Buenos Aires, Argentina, 2018}

Unlike many other events, and perhaps because the procurements were recent or ongoing, there was a considerable amount of public information on the infrastructure procurement for Buenos Aires, which remained online at the time of writing in May 2019. Information such as solicitations, evaluation methodology, award notices, and specifications, was available for all mapped procurements on the official procurement website of the Government of Buenos Aires. ${ }^{300}$ That Government also set up two independent sections within its portal for both the Olympic Park ${ }^{301}$ and Olympic Village projects ${ }^{302}$, providing direct links to the contracts and procurement documentation, as well as information relating to the procuring entity, contractor, stage of performance, type of works and contract value. The event also had a legacy website with a detailed timeline for social, urban, and sport legacies ${ }^{303}$; this includes an open data section with full information on goods and services (although not infrastructure) procurement ${ }^{304}$.

The mapping covered the Olympic Park (63 million USD) and Olympic Village (67 million USD) projects, which appear to have been the only infrastructure projects. There were nine separate procurements leading to nine contracts for the Olympic Park site preparation and construction, and twenty for the Village site preparation and construction, all of which were mapped. The procurements were undertaken at separate times but often with a short window between each - for example, the solicitation notice for Lot III of the Village was published on $23^{\text {rd }}$ April 2015 and that for Lot IV on $11^{\text {th }}$ May - with limits placed on the number available to individual contractors. No reasons could be found for this approach but it could have been to facilitate involvement of small and local contractors.

\footnotetext{
294 "Otwarcie Stadionu Olimpijskiego" (Olympic Stadium Opening Ceremony; authors' translation), April 8, 2017 at https://www.wroclaw.pl/go/wydarzenia/sport-i-rekreacja/35234-otwarcie-stadionu-olimpijskiego (in Polish).

295 Judgment of the National Appeals Chamber of August 26, 2014, file signature KIO 1642/14, at

$\mathrm{ftp}: / /$ ftp.uzp.gov.pl/KIO/Wyroki/2014_1642.pdf; Judgment of the National Appeals Chamber of April 4, 2017, file signature KIO 538/17, at ftp://ftp.uzp.gov.pl/KIO/Wyroki/2017_0538.pdf.

296 https://www.cba.gov.pl/en.

297 https://www.nik.gov.pl/en.

298 https://bip.wroclaw.rio.gov.pl/.

299 "The World Games 2017 Impreza Roku w Plebiscycie Nagrody Sportowe Polskiego Radia!" (The World Games 2017 is the Event of the Year in the Polish Radio Sports Awards!; authors' translation), at https://theworldgames2017.com/the-world-games-2017-impreza-roku-w-plebiscycie-nagrody-sportowepolskiego-radia/ (in Polish).

300 Buenos Aires Ciudad, Buscador Avanzado de Obras (City of Buenos Aires, Advanced Search for Works - title translate from Spanish by Sebastian Barreto-Cifuentes), https://www.buenosaires.gob.ar/baobras/buscadoravanzado-de-obras (in Spanish).

${ }^{301}$ Buenos Aires Ciudad, Parque Olímpico (City of Buenos Aires, Olympic Park; authors' translation). https://www.buenosaires.gob.ar/baobras/parque-olimpico (in Spanish).

302 Buenos Aires Ciudad, Villa Olímpica (City of Buenos Aires, Olympic Village; authors' translation), https://www.buenosaires.gob.ar/baobras/villa-olimpica (in Spanish).

303 Buenos Aires Ciudad, Legado Olímpico (City of Buenos Aires, Olympic Legacy; authors' translation), https://legadoolimpico.buenosaires.gob.ar/ (in Spanish).

304 Buenos Aires Ciudad, Legado Olímpico (City of Buenos Aires, Olympic Legacy; authors' translation), https://legadoolimpico.buenosaires.gob.ar/gobierno-abierto/ (in Spanish).
} 
The entity responsible for this procurement was the Ministry of Urban Development and Transportation of the City of Buenos Aires, a permanent unit of the City Government, with a further special unit created within it for the Games. This Ministry and its units are covered by the regular public procurement legal frameworks of Argentina (Act 13064) and the City of Buenos Aires (Act 5460 plus Decrees). The procurements were directly financed by the Ministry and taken into public sector ownership.

No evidence was found on market research or engagement or on risk management activities directly linked to the project. However, the internal control body (part of the local administration) does have an auditing manual on risk management. ${ }^{305}$

The legal framework offered three procurement procedures: public tender procedure (licitación pública), restricted invitation (licitación privada) and direct award. For all the mapped procurement public tender was used, a type of open public tender under our definition that allows tenders by all interested parties. However, in all procedures at least one registration was necessary - in the National Register of Public Works Builders Registro Nacional de Constructores de Obras Públicas - while the water and sewer contract required two registrations. ${ }^{306}$ This could potentially operate as a barrier to participation, given that the time between solicitation and bid submission was between 15 and 20 days.

In general, the solicitations received a good response, with from four to 16 bids for each contract, and a minimum of three responsive bids. However, for several of the contracts the bidders were the same, and on at least in one occasion the best bidder was rejected because it had already received a contract for the same project. Further, in the case of the Village, in particular, successive procurement of similar projects with similar dimensions, separated only by days, could create a significant risk of collusion.

As mentioned, there was significant electronic publication of documents. However, the extent to which electronic means were used for the procedure (for example, for submissions) is not known.

As regards contract execution, Act 13064, which was applicable to all mapped procurements, includes provisions on performance including substantive limits and approval requirements for amendments, and supervision of the works ${ }^{307}$, as also do the Standard Specifications. ${ }^{308}$ No public information was found on amendments.

Generally, there was no evidence or public suggestion of integrity issues. With the contract for the roof for the Parque Roca the media reported cost-overruns of $76 \%$ and delays, but the auditing body of the Government of Buenos Aires appears to have concluded that this was due to bad planning rather than integrity issues. ${ }^{309}$ Other than this the contracts were performed in a timely and satisfactory manner and generally

\footnotetext{
${ }^{305}$ Buenos Aires Ciudad, Sindicatura General de la Ciudad de Buenos Aires, Manual de Análisis de Riesgos (City of Buenos Aires, General Comptroller of the City of Buenos Aires, Risk Assessment Manual; authors' translation), source available in Spanish at https://www.buenosaires.gob.ar/sindicatura/manual-de-analisis-deriesgos.

${ }^{306}$ As indicated in the specifications.

307 Chapters IV on The Performance of the Works and V on Alterations to the Terms, Articles 25-39 of the 13064 Act of 1947; authors' translation.

${ }^{308}$ Decree 1254 of 2008 of the Government of the Autonomous City of Buenos Aires, Annex: General Specifications for Major Works, Clause 1.6.23 on Supervision, and Clause 1.13 on modifications and new prices; authors' translation.

309 M. Giambartolomei, "Atrasos y exceso de gastos en el estadio de Parque Roca" (Delays and cost overrun in the Roque Park Stadium; authors' translation), La Nación, February 4, 2017, at https://www.lanacion.com.ar/buenos-aires/atrasos-y-exceso-de-gastos-en-el-estadio-de-parque-rocanid1981667 (in Spanish). Although this contract was included in the legacy of the Games, and is often linked to them, the procurement was launched, and the contract concluded, in 2013, 4 years before the other contracts.
} 
Information on procurement of infrastructure for this event - mainly ten stadia (five new build and five refurbished) and transport works - was difficult to locate, and specific procurement information is not generally publicly available. Factors contributing to the difficulties in accessing information include fragmented procurement responsibilities, meaning that consolidated event information is difficult to obtain; the fact that basic eprocurement was introduced in South Africa only in 2015; and the fact that the Local Organising Committee (LOC), the 2010 FIFA World Cup Organising Committee South Africa $^{311}$, was wound up in $2011^{312}$, as were dedicated units created within various government departments. However, some information was obtained from records placed before various oversight bodies in the lead-up to and after the event, such as submissions to parliamentary committees ${ }^{313}$, while information on post-event integrity allegations is available on the websites of the South African Competition Commission ${ }^{314}$ and Competition Tribunal ${ }^{315}$ and in the media ${ }^{316}$ and other literature and commentary. ${ }^{317}$

Mapping was done for one of the five new stadia, the Cape Town stadium, chosen because of its size, because information was available, and because the difficulty of tracking down information precluded mapping other events in the project timescale. The procurement budget for all ten stadia was approximately USD $1037000000^{318}$, with a cost of approximately USD386 680 000for Cape Town making it the single largest procurement $^{319}$. Although the mapping is not concerned directly with legacy unrelated to procurement procedure, it is worth noting as background that despite significant

310 See https://www.buenosaires.gob.ar/baobras/villa-olimpica and https://www.buenosaires.gob.ar/baobras/parque-olimpico, which report start and end dates coinciding with planned performance dates.

${ }^{311}$ Sport \& Recreation South Africa, "2010 FIFA World Cup Country Report" (Pretoria: 2013), p.12, at https://www.gov.za/sites/default/files/gcis_document/201409/srsacountryreport2013-withcovera.pdf; G. Davies, "Managing the alchemy of the 2010 Football World Cup" in U. Pillay, R. Tomlinson and O. Bass (eds), Development and Dreams: The urban legacy of the 2010 Football World Cup (Cape Town: HSRC Press, 2009), p.42.

312 South African Government News Agency, "2010 LOC disbanded" (July 4, 2011), at https://www.sanews.gov.za/south-africa/2010-loc-disbanded.

${ }^{313}$ E.g. Financial and Fiscal Commission Report: Briefing to the National Assembly Public Works Portfolio Committee, October 10, 2007, at https://pmg.org.za/committee-meeting/8387/; National Treasury presentation on status of funding of 2010 World Cup stadiums to the National Assembly Finance Portfolio Committee, March 7, 2007, at https://pmg.org.za/committee-meeting/7831/; World Cup 2010 Host Cities on Alleged Funding Crisis for Stadia: Briefing to the National Assembly Sport and Recreation Portfolio Committee, January 23, 2007, at https://pmg.org.za/committee-meeting/7657/; Sport and Recreation Portfolio Committee and Provincial and Local Government Portfolio Committee, Parliament of the Republic of South Africa, "2010 World Cup: 9 Hosting Cities' State of Readiness: Briefings", August 29, 2006, at

https://pmg.org.za/committee-meeting/7256/; Public Works Portfolio Committee, Parliament of the Republic of South Africa, "Follow-up on collusion in construction industry: input by Deputy Minister of Public Works, Competition Commission \& Construction Industry Development Board", September 9, 2013, at https://pmg.org.za/committee-meeting/16318/.

${ }^{314}$ Competition Commission of South Africa, "2010 FIFA World Cup Stadia Referral" (Media Advisory, November 13, 2014), at http://www.compcom.co.za/media-advisory-13-november-2014-2010-fifa-world-cup-stadiareferral/.

315 Competition Tribunal South Africa, Consent Orders 016949; 016956; 016964; 016980; 016998; 017004; 017020; 017038; 017046; 017053; 017061; 017012; 017277; 016931; and 016972, at https://www.comptrib.co.za/cases/consent-order/?year=2014.

316 See e.g. Z. Nicholson, "World Cup stadium collusion revealed", Business Report, July 16, 2013, at https://www.iol.co.za/business-report/companies/world-cup-stadium-collusion-revealed-1547328; L. Steyn, "World Cup stadium construction cartel gets its comeuppance", Mail \& Guardian, December 4, 2015, at https://mg.co.za/article/2015-12-03-remaining-2010-world-cup-stadium-colluders-face-prosecution; C. Benjamin and P. De Wet, "The flaw that broke the construction cartel's back", Mail \& Guardian, July 19, 2013 https://mg.co.za/article/2013-07-19-00-the-flaw-that-broke-the-construction-cartels-back.

317 See in particular C. Schulz Herzenberg (ed.), Player and referee: Conflicting interests and the 2010 FIFA World Cup ${ }^{T M}$ [e-book] (Pretoria: Institute of Security Studies, 2010), at http://ccs.ukzn.ac.za/files/ISS\%20Player\%20and\%20Referee.pdf.

318 Sport \& Recreation South Africa, "2010 FIFA World Cup Country Report" (Pretoria: 2013), p.45, at https://www.gov.za/sites/default/files/gcis_document/201409/srsacountryreport2013-withcovera.pdf. ${ }^{319}$ Sport \& Recreation South Africa, "2010 FIFA World Cup Country Report" (Pretoria: 2013), p.45, at https://www.gov.za/sites/default/files/gcis_document/201409/srsacountryreport2013-withcovera.pdf. 
emphasis on legacy during planning, ${ }^{320}$ a strong argument has been made that the Cape Town stadium is a white elephant ${ }^{321}$ that does not fulfil any local need, is not financially viable, will rely on public subsidy for a long time and contributed little to development. ${ }^{322}$

As generally with major events, the LOC had minimal involvement in the major infrastructure procurement. ${ }^{323}$ This was mainly undertaken by entities within whose ordinary mandate aspects of the event fell. All stadia were accordingly procured by the local authorities of the host cities while national road and rail procurement, for example, was facilitated by the Department of Transport and dedicated transport entities (Passenger Rail Agency of South Africa (Prasa) and South African National Roads Agency Limited (SANRAL)) and other infrastructure by numerous other entities. ${ }^{324}$ However, a 2010 Unit was set up in the National Treasury to coordinate financial aspects, including for all infrastructure development, which included a Procurement Task Team assisting host cities with procurement ${ }^{325}$.

This approach meant that the City of Cape Town procured the Cape Town stadium. ${ }^{326}$ In doing so, the City followed the regular procurement rules for local government infrastructure in South Africa. This is largely done in terms of the Local Government: Municipal Finance Management Act 56 of 2003, which provides a distinct set of rules, primarily in the Municipal Supply Chain Management Regulations, 2005, promulgated under the Act, for local government procurement. ${ }^{327}$ Under this regime, each local government must establish its own Supply Chain Management Policy with its own detailed procurement rules, which may differ considerably. The rules of the Construction Industry Development Board on public procurement, created under the Construction Industry Development Board Act 38 of 2000,328 applicable to works procurement, also applied. The procurement was also subject to the Preferential Procurement Policy

320 G. Davies, "Managing the alchemy of the 2010 Football World Cup" in U. Pillay, R. Tomlinson and O. Bass (eds), Development and Dreams: The urban legacy of the 2010 Football World Cup (Cape Town: HSRC Press, 2009), p.44.

${ }^{321}$ K. Schoonbee and S. Brümmer, "Public loss, FIFA's gain: How Cape Town got its 'white elephant", in C. Schulz Herzenberg (ed.), Player and referee: Conflicting interests and the 2010 FIFA World Cup ${ }^{T M}$ [e-book] (Pretoria: Institute of Security Studies, 2010), Ch.6, pp.133-167 at pp.158-159, at http://ccs.ukzn.ac.za/files/ISS\%20Player\%20and\%20Referee.pdf.

322 Subsequent figures of running costs against income derived from the stadium seem to support these arguments, with the City revealing in 2013 that operating costs since the 2009/10 financial year stood at about USD30 million while the income for that period was about USD6.5 million: OnlineTenders, "Bid to get Cape Town Stadium millions back" (2013), at https://www.onlinetenders.co.za/news/bid-to-get-cape-town-stadiummillions-back.

${ }^{323}$ While the LOC considered itself a private entity, including for purposes of its procurement activities, the High Court ruled that it was in fact exercising public power and thus constituted a public entity in its procurement functions in the matter of M \& G Limited v 2010 FIFA World Cup Organising Committee South Africa Limited [2010] ZAGPJHC 43, June 8, 2010, http://www.saflii.org/za/cases/ZAGPJHC/2010/43.pdf. This matter involved a request under South Africa's freedom of information legislation, the Promotion of Access to Information Act 2 of 2000 for access to the LOC's procurement records.

${ }^{324}$ E.g. roads by the relevant cities; airport infrastructure procurement by the Airports Company South Africa (ACSA); and upgraded border facilities by the Department of Public Works - Sport \& Recreation South Africa, "2010 FIFA World Cup Country Report" (Pretoria: 2013), pp. 29-30, 53, 124-128, 130, 146, 150, 173, at https://www.gov.za/sites/default/files/gcis_document/201409/srsacountryreport2013-withcovera.pdf. Procurement for the overall event consisted of 24 sub-projects, National Treasury presentation on status of funding of 2010 World Cup stadiums to the National Assembly Finance Portfolio Committee, March 7, 2007, at https://pmg.org.za/committee-meeting/7831/.

325 There was also a 2010 FIFA World Cup Government Coordinating Unit within the National Department of Sports and Recreation that provided coordination of all aspects of the event.

${ }^{326}$ Sport and Recreation Portfolio Committee and Provincial and Local Government Portfolio Committee, Parliament of the Republic of South Africa, "2010 World Cup: 9 Hosting Cities' State of Readiness: Briefings", August 29, 2006, at https://pmg.org.za/committee-meeting/7256/.

327 These rules are distinct from procurement rules applied to procurement at national and provincial levels, which is governed by the Public Finance Management Act 1 of 1999 and that does not apply to local government.

328 These are primarily the Construction Industry Development Regulations, Government Notice R8986 in Government Gazette 31603 of 14-11-2008; Construction Industry Development Regulations, Government Notice R464 in Government Gazette 36629 of 02-07-2013 and the CIDB Standard for Uniformity in Construction Procurement, Government Gazette 33239 of 28-05-2010. 
Framework Act 5 of 2000 which, in particular, grants preferences under South Africa's broad-based black economic empowerment policy. ${ }^{329}$

The Cape Town stadium was designed by a professional team, based on FIFA and LOC requirements. ${ }^{330}$ The demolition of the existing Green Point stadium on the site and the construction of the new stadium based on the design were then put out to tender in a single procedure ${ }^{331}$, although there was a delay in commencing construction while funding was secured. The procurement received funding from national, provincial and local levels ${ }^{332}$ and the stadium is owned by the City. ${ }^{333}$

The evidence suggests very little market engagement and research during the planning phase. In April 2006 (less than a year before construction had to start), the newly elected mayor stated that the expected studies and costings had not been done. ${ }^{334} \mathrm{~A}$ subsequent feasibility study suggested that the Cape Town stadium was not the best option, but there is no indication of market engagement for the actual procurement. The extent of cost overruns and adjustments that occurred in the stadia procurement generally, including for Cape Town, suggest some inadequacies of planning, as explained later.

One of the seven board committees of the LOC was the Audit \& Risk Committee responsible for implementing effective risk management. ${ }^{335}$ At the highest governance level there was thus focused attention to risk management from the outset. At the operational level, the LOC's Chief Risk Officer reporting to the Chief Operating Officer had primary operational responsibility for risk management. ${ }^{336}$ In the preparations, it is clear that a number of procurement risks were identified and actions taken to manage them ${ }^{337}$. For example, a particular risk identified as the solicitations were published was the very high level of provisional sums, in some instances up to $60 \%$ of the amounts of

\footnotetext{
${ }^{329}$ At that time the detailed rules on preferential procurement under this policy were set out in the Preferential Procurement Regulations, 2001.

${ }^{330}$ World Cup 2010 Host Cities on Alleged Funding Crisis for Stadia: Briefing to the National Assembly Sport and Recreation Portfolio Committee, January 23, 2007, at https://pmg.org.za/committee-meeting/7657/; K. Schoonbee and S. Brümmer, "Public loss, FIFA's gain: How Cape Town got its 'white elephant'", in C. Schulz Herzenberg (ed.), Player and referee: Conflicting interests and the 2010 FIFA World Cup ${ }^{T M}$ (Pretoria: Institute of Security Studies, 2010), Ch.6, pp.133-167 [e-book], at http://ccs.ukzn.ac.za/files/ISS\%20Player\%20and\%20Referee.pdf.

${ }^{331}$ World Cup 2010 Host Cities on Alleged Funding Crisis for Stadia: Briefing to the National Assembly Sport and Recreation Portfolio Committee, January 23, 2007, at https://pmg.org.za/committee-meeting/7657/. ${ }_{332}$ Sport \& Recreation South Africa, "2010 FIFA World Cup Country Report" (Pretoria: 2013), pp.45 \& 55, at https://www.gov.za/sites/default/files/gcis_document/201409/srsacountryreport2013-withcovera.pdf; Schoonbee and S. Brümmer, "Public loss, FIFA's gain: How Cape Town got its 'white elephant'", in C. Schulz Herzenberg (ed.), Player and referee: Conflicting interests and the 2010 FIFA World Cup ${ }^{T M}$ (Pretoria: Institute of Security Studies, 2010), Ch.6, pp.133-167 [e-book], at http://ccs.ukzn.ac.za/files/ISS\%20Player\%20and\%20Referee.pdf; G. Davies, "Managing the alchemy of the 2010 Football World Cup" in U. Pillay, R. Tomlinson and O. Bass (eds), Development and Dreams: The urban legacy of the 2010 Football World Cup (Cape Town: HSRC Press, 2009), pp.46-48.

${ }^{333}$ Not all stadia for the event are similarly publicly owned, although all were predominantly publicly financed see G. Davies, "Managing the alchemy of the 2010 Football World Cup" in U. Pillay, R. Tomlinson and O. Bass (eds), Development and Dreams: The urban legacy of the 2010 Football World Cup (Cape Town: HSRC Press, 2009), p.35.

${ }^{334}$ Schoonbee and S. Brümmer, "Public loss, FIFA's gain: How Cape Town got its 'white elephant'", in C. Schulz Herzenberg (ed.), Player and referee: Conflicting interests and the 2010 FIFA World Cup ${ }^{\text {TM }}$ (Pretoria: Institute of Security Studies, 2010), Ch.6, pp.133-167 at p.146 [e-book], at http://ccs.ukzn.ac.za/files/ISS\%20Player\%20and\%20Referee.pdf.

335 Sport \& Recreation South Africa, "2010 FIFA World Cup Country Report" (Pretoria: 2013), pp.12-13, at https://www.gov.za/sites/default/files/gcis_document/201409/srsacountryreport2013-withcovera.pdf. ${ }^{336}$ Sport \& Recreation South Africa, "2010 FIFA World Cup Country Report" (Pretoria: 2013), p.16, at https://www.gov.za/sites/default/files/gcis_document/201409/srsacountryreport2013-withcovera.pdf. 337 This emerges, for example, from a number of oversight reports, submitted to various bodies such as parliamentary portfolio committees, prior to the event, that show an awareness of a range of risks and actions taken to address these. See e.g. National Treasury presentation on status of funding of 2010 World Cup stadiums to the National Assembly Finance Portfolio Committee, March 7, 2007, at https://pmg.org.za/committee-meeting/7831/; World Cup 2010 Host Cities on Alleged Funding Crisis for Stadia: Briefing to the National Assembly Sport and Recreation Portfolio Committee, January 23, 2007, at https://pmg.org.za/committee-meeting/7657/.
} 
bills of quantities. ${ }^{338}$ The 2010 Unit within National Treasury, which we saw included a Procurement Task Team, identified this risk and implemented mitigation strategies. This Unit had regular interaction with the implementing institutions, such as host cities, on the management of emerging risks. ${ }^{339}$ Subsequent to the event the main government Department involved, Sport \& Recreation, reviewed the risks that emerged and formulated lessons, ${ }^{340}$ a number of which focused on procurement and, in particular, the stadia construction. ${ }^{341}$ At local level, Cape Town has since introduced greater transparency measures in procurement although the influence of the World Cup experience on this is unclear. ${ }^{342}$

The legal framework prescribed an open public tender for the stadia procurements. ${ }^{343}$ Pre-qualification was required, however, under the grading system of the Construction Industry Development Board. ${ }^{344}$ Direct awards were available only in exceptional circumstances and were not used for the mapped procurement. Limited negotiations could be done with the preferred bidder(s), primarily relating to costs. The procedure was conducted over two stages with only bidders shortlisted during the first stage ${ }^{345}$ invited to submit final bids. Award criteria were price (90 points out of 100) and broadbased black economic empowerment status as prescribed by the 2000 Act (10 points). At the time there was virtually no use of electronic procurement and communications in South Africa, with limited initiatives introduced only much later. ${ }^{346}$

Only a limited number of bids were received, as also with the other stadia procurements $^{347}$, and only two bidders (both joint ventures) invited to submit secondstage bids ${ }^{348}$. At the time this was ascribed to the limited number of qualifying, large construction companies operating in South Africa and the number of concurrent projects relating to both the World Cup and other infrastructure. ${ }^{349}$ However, it subsequently emerged that there were significant levels of collusion, as discussed later. The limited number of bids evidently impacted adversely on the cost and the City is currently pursuing a damages claim against some contractors. ${ }^{350}$

There were no challenges in the High Court relating to the Cape Town stadium, despite such challenges being frequent in South Africa for large procurements. ${ }^{351}$ However, this

\footnotetext{
338 National Treasury presentation on status of funding of 2010 World Cup stadiums to the National Assembly Finance Portfolio Committee, March 7, 2007, at https://pmg.org.za/committee-meeting/7831/.

339 Sport \& Recreation South Africa, "2010 FIFA World Cup Country Report" (Pretoria: 2013), p.55, at https://www.gov.za/sites/default/files/gcis_document/201409/srsacountryreport2013-withcovera.pdf. 340 Sport \& Recreation South Africa, "2010 FIFA World Cup Country Report" (Pretoria: 2013), at

https://www.gov.za/sites/default/files/gcis_document/201409/srsacountryreport2013-withcovera.pdf.

${ }_{341}$ See Sport \& Recreation South Africa, "2010 FIFA World Cup Country Report" (Pretoria: 2013), pp.45 \& 50, at https://www.gov.za/sites/default/files/gcis_document/201409/srsacountryreport2013-withcovera.pdf. 342 C. Schulz Herzenberg, "Conclusions and recommendations", in C. Schulz Herzenberg (ed.) Player and referee: Conflicting interests and the 2010 FIFA World Cup ${ }^{T M}$ (Pretoria: Institute of Security Studies, 2010), Ch.8, pp.203-213 at p.211 [e-book], at http://ccs.ukzn.ac.za/files/ISS\%20Player\%20and\%20Referee.pdf. 343 Municipal Supply Chain Management Regulations, regulation 12(1)(d).

344 See A.M. Anthony, The Legal Regulation of Construction Procurement as a Relational Construct in South Africa (LLD dissertation, Stellenbosch University, 2018), pp.161-162, available via https://scholar.sun.ac.za/handle/10019.1/103815.

${ }^{345}$ It is not known what kind of criteria were applied at this stage.

${ }^{346}$ See G. Kramer, "Electronic Public Procurement as a Tool of Reform in South African Public Procurement" (2016) 3:1 African Public Procurement Law Journal 1.

${ }^{347}$ See e.g. Nelson Mandela Bay Municipality, "Report to Portfolio Committee on Sport and Recreation" (2007), at https://pmg.org.za/committee-meeting/7657/.

${ }^{348}$ City of Cape Town $v$ WBHO Construction (Pty) Ltd and Others (86873/2014) [2017] ZAGPPHC 271 (March 31, 2017), at http://saflii.org/za/cases/ZAGPPHC/2017/271.html.

${ }^{349}$ National Treasury presentation on status of funding of 2010 World Cup stadiums to the National Assembly Finance Portfolio Committee, March 7, 2007, at https://pmg.org.za/committee-meeting/7831/.

350 See City of Cape Town $v$ WBHO Construction (Pty) Ltd and Others (86873/2014) [2017] ZAGPPHC 271 (March 31, 2017), at http://saflii.org/za/cases/ZAGPPHC/2017/271.html.

${ }^{351}$ As the South African Supreme Court of Appeal stated in South African Post Office $v$ De Lacy 2009 (5) SA 255 (SCA): "Cases concerning tenders in the public sphere are coming before the courts with disturbing frequency." See G. Quinot, "Enforcement of Procurement Law from a South African Perspective" (2011) 20 P.P.L.R. 193.
} 
might have been because of collusion. There were a number of challenges to other event procurements ${ }^{352}$.

Execution of the contract, including payments, was closely monitored by both the City and oversight entities, such as the National Treasury, which facilitated the bulk of the financing, and LOC. ${ }^{353}$ While some monitoring information became publicly available via reports to entities, such as parliamentary portfolio committees, ${ }^{354}$ information about execution and progress was not generally publicly available. Strict rules governed amendments, generally requiring procuring entities to deal with deviations to contracts through the formal supply chain management function of the entity, and the cost overruns were subjected to these rules. ${ }^{355}$

As mentioned, a feature of the stadia procurements, including Cape Town, was the very significant mismatch between the planning and implementation, most evident in major cost overruns. The initial cost estimate for the Cape Town stadium was approximately USD128 000 000, whereas the lowest tender was for approximately USD183000 000, ${ }^{356}$ and the eventual cost approximately USD $386680000 .{ }^{357}$ During the planning phase, the significant level of provisional sums used in tender documents was specifically pointed out as a risk. ${ }^{358}$ National Treasury reported to Parliament that this was an indication that "[t]he professional teams probably did not do good work to finalise the tender documents." 359 Major adjustments also had to be made to design as the project unfolded, such as eliminating certain features (for example, a sliding roof) ${ }^{360}$ and procuring additional work on the concrete frame to stiffen the structure, because detailed designs were not done during the planning. ${ }^{361}$

Despite initial fears, and some reports of irregularities ${ }^{362}$, South Africa was not beset by major corruption allegations, and arguably illustrates the dividends that may be paid by a major political effort to prevent political interference and corruption in a major

\footnotetext{
352 E.g. Lohan Civil-Tebogo Joint Venture v Mangaung Plaaslike Munisipaliteit (508/2009) [2009] ZAFSHC 46 (April 6, 2009), at http://www.saflii.org/za/cases/ZAFSHC/2009/46.html, where the High Court invalidated an award of a tender for road construction; and Digital Horizons (Pty) Ltd v SA Broadcasting Corporation and Another (2008/19224) [2008] ZAGPHC 272 (September 8, 2008), at

http://www.saflii.org/za/cases/ZAGPHC/2008/272.pdf, where an application for interim relief to stop the implementation of a contract awarded for the supply of broadcasting vehicles to the national broadcaster for purposes of the event was dismissed.

353 See G. Davies, "Managing the alchemy of the 2010 Football World Cup" in U. Pillay, R. Tomlinson and O. Bass (eds), Development and Dreams: The urban legacy of the 2010 Football World Cup (Cape Town: HSRC Press, 2009), p.37.

${ }^{354}$ See e.g. World Cup 2010 Host Cities on Alleged Funding Crisis for Stadia: Briefing to the National Assembly Sport and Recreation Portfolio Committee, January 23, 2007, at https://pmg.org.za/committee-meeting/7657/. ${ }^{355}$ Schoonbee and S. Brümmer, "Public loss, FIFA's gain: How Cape Town got its 'white elephant'", in C. Schulz Herzenberg (ed.), Player and referee: Conflicting interests and the 2010 FIFA World Cup ${ }^{T M}$ (Pretoria: Institute of Security Studies, 2010), Ch.6, pp.133-167 at pp.148-149 [e-book], at http://ccs.ukzn.ac.za/files/ISS\%20Player\%20and\%20Referee.pdf.

356 M. Marsden, "Presentation to the Portfolio Committee on Sport and Recreation - funding of 2010 stadia" available via World Cup 2010 Host Cities on Alleged Funding Crisis for Stadia: Briefing to the National Assembly Sport and Recreation Portfolio Committee, January 23, 2007, at https://pmg.org.za/committee-meeting/7657/. 357 Sport \& Recreation South Africa, "2010 FIFA World Cup Country Report" (Pretoria: 2013), p.45, at https://www.gov.za/sites/default/files/gcis_document/201409/srsacountryreport2013-withcovera.pdf.

358 National Treasury presentation on status of funding of 2010 World Cup stadiums to the National Assembly Finance Portfolio Committee, March 7, 2007, at https://pmg.org.za/committee-meeting/7831/.

${ }^{359}$ National Treasury presentation on status of funding of 2010 World Cup stadiums to the National Assembly Finance Portfolio Committee, March 7, 2007, at https://pmg.org.za/committee-meeting/7831/.

360 M. Marsden, "Presentation to the Portfolio Committee on Sport and Recreation - funding of 2010 stadia" available via World Cup 2010 Host Cities on Alleged Funding Crisis for Stadia: Briefing to the National Assembly Sport and Recreation Portfolio Committee, January 23, 2007, at https://pmg.org.za/committee-meeting/7657/. 361 Schoonbee and S. Brümmer, "Public loss, FIFA's gain: How Cape Town got its 'white elephant"', in C. Schulz Herzenberg (ed.), Player and referee: Conflicting interests and the 2010 FIFA World Cup ${ }^{T M}$ (Pretoria: Institute of Security Studies, 2010), Ch.6, pp.133-167 at pp.148-149 [e-book], at http://ccs.ukzn.ac.za/files/ISS\%20Player\%20and\%20Referee.pdf.

362 R. Rose, "Soccer City: What it says about the murky world of government tenders", in C. Schulz Herzenberg (ed.), Player and referee: Conflicting interests and the 2010 FIFA World Cup ${ }^{T M}$ (Pretoria: Institute of Security Studies, 2010), Ch.2, pp.21-49 [e-book], at http://ccs.ukzn.ac.za/files/ISS\%20Player\%20and\%20Referee.pdf.
} 
event $^{363}$. However, as noted, major collusion issues emerged. Investigations by the competition authorities from 2008 revealed that the major construction companies that won the stadia work, including on the Cape Town stadium, and other infrastructure projects, colluded in securing the work and several were fined ${ }^{364}$ based on admissions of guilt and settlement with the Competition Commission, confirmed by the Competition Tribunal $^{365}$.

\subsection{FINA World Championships, Budapest, Hungary, 2017}

Much information on the procurement for this event was available after the event from the Public Procurement Authority database. ${ }^{366}$ Although there were no open public tenders (see below), national legislation still required entities to publish information, including an award notice, summary of the bid evaluation, the concluded contract and information on execution ${ }^{367}$. Although the database does not contain every required document, it does include the award notice for all procedures, the contract and amendments for many, and, in some cases, a summary of the evaluation and a document on contract execution; and procedural information such as the number of bidders, type of procedure and certain timescales was also available. The value of bids and signed contracts and amounts finally paid could also be extracted. On the other hand, it was impossible or difficult to obtain information not directly related to the procedures, including price estimates in the bid to host the event or pre-event analyses. For procurements conducted by the Hungarian National Asset Management Inc. much information was also available on its website ${ }^{368}$, as was also the case for procurements by the National Sports Centres non-profit organisation. However, very little information was found on BP 2017 World Championship Organising and Conducting Nonprofit (BP $2017)^{369}$, which was the main organising body and responsible for most procedures. Information, including allegations of corruption, was found on websites in Hungarian ${ }^{370}$ and (some) English websites ${ }^{371}$ and the website of anti-corruption NGO atlatszo.hu was a useful source on $\operatorname{costs}^{372}$, although information on these websites was not confirmed by official public sources.

A search revealed at least 32 procurement procedures directly related to the organisation and execution of the event, and there were also others, such as for works around the city. The present study mapped the construction of the main infrastructure at

\footnotetext{
${ }^{363}$ R. Calland, L Naidoo and A. Whaley, The Vuvuzela Revolution: Anatomy of South Africa's World Cup (Auckland Park: Jacana Media, 2011).

364 See: Competition Commission of South Africa, "Referral of Complaint by Commission" to the Competition Tribunal of South Africa (November 12, 2014), available via http://www.compcom.co.za/media-advisory-13november-2014-2010-fifa-world-cup-stadia-referral/\#; Public Works Portfolio Committee, Parliament of the Republic of South Africa, "Follow-up on collusion in construction industry: input by Deputy Minister of Public Works, Competition Commission \& Construction Industry Development Board", September 9, 2013, at https://pmg.org.za/committee-meeting/16318/; "Collusion in Built Environment Investigation Outcomes: Council for Built Environment, Construction Industry Development Board \& Competition Commission, with Minister", briefing to the Portfolio Committee on Public Works of Parliament, March 15, 2016, at https://pmg.org.za/committee-meeting/22213/; City of Cape Town v WBHO Construction (Pty) Ltd and Others (86873/2014) [2017] ZAGPPHC 271 (March 31, 2017), at http://saflii.org/za/cases/ZAGPPHC/2017/271.html. 365 See, for example, Competition Tribunal of South Africa Consent Order: Competition Commission and Aveng Africa (Pty) Ltd, Case number: CO043Jun13 (July 23, 2013), at https://www.comptrib.co.za/case-detail/6034. 366 http://www.kozbeszerzes.hu/adatbazis/keres/hirdetmeny.

367 2015. évi CXLIII. törvény a közbeszerzésekről (Act CXLIII of 2015 on Public Procurement; authors' translation), art.43.

368 http://www.mnvzrt.hu/en.

369 https://szervezo.fina-budapest2017.com/en.

370 These included https://index.hu, https://hvg.hu, https://magyarnemzet.hu, https://444.huand http://www.atv.hu.

${ }_{371}$ Information in English was available, in particular, at https://budapestbeacon.com/ and https://dailynewshungary.com/.

372 B. Csepregi, "90 milliárd forintba fog kerülni a 2017-es vizes-vb - kiszámoltuk a kormány helyett" ("Water Sports World Championship is to cost 90 billion HUF - we have calculated it instead of the government"; authors' translation), Atlatszo, May 17, 2016. Article available in Hungarian at: https://atlatszo.hu/2016/05/17/90-milliard-forintba-fog-kerulni-a-2017-es-vizes-vb-kiszamoltuk-a-kormanyhelyett/.
} 
the five main competition venues (involving 14 procedures): the Danube Arena (swimming, diving), the main piece of new infrastructure; Hajós Alfréd Swimming Pool (water polo) and Lake Balaton (open water swimming), both involving significant refurbishment/development; and City Park (synchronised swimming) and Batthyányi Square (high diving), which were new but temporary venues.

BP 2017 was set up as a 100\%-owned state company ${ }^{373}$ specifically for organisational, operational and management aspects of the event. This body was responsible for most procurement, although mapped procurements were also done by the Hungarian National Asset Management Inc (procurements for construction of the Danube Arena and works for high diving), and National Sport Centres - a public body responsible for managing sport venues (refurbishment works for Hajós Alfréd Swimming Pool). All are listed on the Public Procurement Authority website as entities subject to the public procurement legal framework ${ }^{374}$ which is based on the EU directives. Of the mapped procurements, the design and construction were undertaken separately for the high diving facility but not for the others. None of the procurements, including the mapped procurements, used private financing.

As regards risk management, Hungarian National Asset Management Inc and National Sports Centres, as permanent organisations, carry out risk management activites generally, and information on their management and finances is published on their websites as required by law; and the former has a published Code of Ethics including on integrity management. ${ }^{375}$ On the other hand no information was found on any specific risk management activities of BP 2017. Besides the general information ${ }^{376}$, there was also evidence that BP 2017 procured expert risk management services ${ }^{377}$; however no published reports were found on risk management relating to the Championships.

As to planning, Budapest originally won the bid for the 2021 Championships but after the Mexican city of Guadalajara withdrew from the 2017 event Budapest offered to step in and was announced as the new host on 11 March 2015, giving just over two years to complete preparations. This was alleged to justify use of the EU's negotiated procedure without a call for competition, allowed by EU procurement law when "extreme urgency" precludes use of other procedures ${ }^{378}$. No more specific information was found on the planning phase. In this respect, the general national legal framework was supplemented with specific legislation, Act XXXIII of 2015 on the Development of Installations Necessary for the Swimming, Water Polo, Diving, Synchronised Swimming and Open Water World Championships to be Organised in Budapest (FINA Act) ${ }^{379}$, permitting the contracts for the event to be procured in general through this exceptional procedure. The

\footnotetext{
${ }^{373}$ BP 2017 was headed by an Organising Committee that involved key government ministers, the mayor of Budapest and the government commissioner responsible for top priority investments in Budapest. The president was Miklós Seszták, who was Minister for National Development at the time.

${ }_{374}$ As falling within the definition of contracting authorities under the Public Contracts Directive.

${ }^{375}$ Az MNV Zrt. Etikai Kódexe, 27/2013. számú vezérigazgatói utasítás ("Code of Ethics of MNV Ltd, CEO order no. 27/2013"; authors' translation). Available in Hungarian at:

http://www.mnvzrt.hu//data/cms939218/Etikai_Kodex.pdf.

376 See also the general financial information available through the national register of companies: https://nemzeticegtar.hu/nemzeticegtar/cegadat/0109206809/Bp2017-Vilagbajnoksag-Szervezo-esLebonyolito-Nonprofit-Korlatolt-Felelossegu-Tarsasag (content in Hungarian).

377 Data on the procedure is available in the Hungarian public procurement database. Subject matter of the procurement: A „17. FINA Világbajnokság” előkészítése és lebonyolítása érdekében egyes elemzői és kockázatmenedzsment szakértői kompetenciák igénybevétele ("access to analytical and risk management expert competences for the preparation and running of the $17^{\text {th }}$ FINA World Championships", translation from Hungarian by Gabor Soos). Data concerning the procurement are available in Hungarian at: https://www.kozbeszerzes.hu/adatbazis/megtekint/hirdetmeny/portal_7324_2017/.

378 Art. 32(2)(c) of Directive 2014/24/EU of the European Parliament and of the Council of 26 February 2014 on public procurement and repealing Directive 2004/18/EC [2014] O] L 94/65 (Public Contracts Directive).

379 2015. évi XXXIII. törvény a Budapesten megrendezendő Úszó-, Vízilabda-, Múugró, Műúszó és Nyíltvízi Világbajnokság megvalósításához szükséges létesítményfejlesztésről ("Act XXXIII of 2015 on the Development of Installations Necessary for the Swimming, Water Polo, Diving, Synchronised Swimming and Open Water World Championships to be Organised in Budapest"; authors' translation). The Act is available in Hungarian at http://njt.hu/cgi_bin/njt_doc.cgi?docid=174909.323292.
} 
Hungarian rules for the procedure (supplementing those of EU law) were followed under Act CXLIII of 2015 on Public Procurement ${ }^{380}$, with usually 3 three contractors being invited to bid and the award almost always based on lowest price. It is notable that for most procedures for which this information was available the time from soliciting bids to contract signature was extremely short, often only 8-9 days, so that bidders without advance information would have had very short preparation time. Electronic procedures were not used ${ }^{381}$.

As noted, contract information was published as required by law for some but not all procurements. The Public Procurement Authority has a general right to control contract execution ${ }^{382}$, based on a sample and involving checking documents and site visits, but no information was found on the exercise of this control here.

Hungary completed the necessary procurements on time but, as discussed, there was a notable lack of transparency and the perception in some media was that the costs were extraordinarily high and that many contracts were awarded to persons connected with Government ministers. ${ }^{383}$ The event's initial cost estimate was a modest HUF 24.5 billion (91.26 million USD) but the final bill was around HUF 170 billion ( 633.15 million USD) $)^{384}$. The largest increase was for the Danube Arena, the design of which was altered significantly from the original plans. However, there are no cases known where allegations of corruption were proven before a court or state authority.

\subsection{Asian Games and Asian Para Games, Guangzhou, China, 2010}

In general, there was limited public information for Guangzhou at the time of the research in 2018. Very few procurement documents, including tender documents or contracts, were available, although there were some notices for public tenders (advance notices, solicitations etc) online. ${ }^{385}$ The main information sources were media reports and official websites of the procuring entities, providing only piecemeal information. This could indicate an absence of transparency giving rise to integrity risks and, as explained below, various allegations of corruption were indeed raised; but the position must also

\footnotetext{
380 2015. évi CXLIII. törvény a közbeszerzésekről ("Act CXLIII of 2015 on Public Procurement"; authors' translation). The Act can be accessed in English through the following link: http://www.kozbeszerzes.hu/cikkek/hungarian-public-procurement-rules.

381 These are now required by law (since April 2018, as envisaged under EU law). See arts.40-41 of Act CXLIII of 2015 on Public Procurement and art. 22 of Directive 2014/24/EU.

382 The legal basis for this is provided by: 308/2015. (X. 27.) Korm. rendelet a közbeszerzési eljárás eredményeként megkötött szerződések teljesítésének és módosításának Közbeszerzési Hatóság által végzett ellenőrzéséről ("Government Decree 308/2015 of October 27, 2015, on control by the Public Procurement Authority of contracts concluded as a result of a public procurement procedure and their modification"; authors' translation). Available in Hungarian at: http://njt.hu/cgi_bin/njt_doc.cgi?docid=191802.366281

${ }^{383}$ For a summary in English on the rising costs and contracts awarded see: B. Pivarnyik, "FINA 2017: The story behind the biggest and most expensive sports event in Hungary's history", The Budapest Beacon, July 14, 2017, at https://budapestbeacon.com/fina-2017-story-behind-biggest-expensive-sports-event-hungaryshistory/. Articles in Hungarian include: Z. Jandó, "Óriásit kaszáltak a vizes vb első nyertesei" ("Huge amounts have been won by the first winners of the Water Sports World Championships"; authors' translation), Magyar Nemzet, June 3, 2017, available in Hungarian at: https://mno.hu/belfold/oriasit-kaszaltak-a-vizes-vb-elsonyertesei-2401779; "Így szabadult el a vizes vb költségvetése" ("This is how the budget of the Water Sports World Championships got out of control"; authors' translation), HVG, July 10, 2017, available in Hungarian at: https://hvg.hu/sport/20170710_igy_szabadult_el_a_vizes_vb_koltsegvetese.

384 One article mentions that the same event in Kazan in Russia, cost only RUB 3.5 billion (HUF 16 billion, USD 54 million), although this cost did not include any related works around the city. See: "Így szabadult el a vizes vb költségvetése" ("This is how the budget of the Water Sports World Championships got out of control"; authors' translation), HVG, July 10, 2017, available in Hungarian at:

https://hvg.hu/sport/20170710_igy_szabadult_el_a_vizes_vb_koltsegvetese. See in English: B. Pivarnyik, "FINA 2017: The story behind the biggest and most expensive sports event in Hungary's history", The Budapest Beacon, July 14, 2017, at https://budapestbeacon.com/fina-2017-story-behind-biggest-expensivesports-event-hungarys-history/.

${ }^{385}$ For example, for the Asian Games Village, 13 public notices were found, including advance notices of upcoming contracts, solicitations and notice on the results of qualification, available at http://www.gzlpc.gov.cn/sofpro/bmyyqt/sitesearch/search.jsp?websiteId=e9785b8e787a44b99200a77bcb1bf0 c8\&color $=\% 2312589$ \& w websiteName $=\%$ E5\%B9\%BF\%E5\%B7\%9E\%E5\%B8\%82\%E8\%A7\%84\%E5\%88\%92\%E $5 \% 92 \% 8 C \% E 8 \% 87 \% A A \% E 7 \% 84 \% B 6 \% E 8 \% B 5 \% 84 \% E 6 \% B A \% 90 \% E 5 \% B 1 \% 80 \&$ startDate=\&gjz=\%E4\%BA\% $9 \mathrm{~A} \% \mathrm{E} 8 \% \mathrm{BF} \% 90 \% \mathrm{E} 6 \% 9 \mathrm{D} \% 91 \& \mathrm{curPageNo}=1$ \&pagination_input= (all sources in Chinese) .
} 
be seen in the light of the limited use of electronic means before 2010, when there was no unitary online portal for procurement information and documents may not generally have been electronic or archived in that form. Moreover, historical data is commonly erased in China, especially at sub-central level, when websites are updated or transferred to new IP addresses ${ }^{386}$ and particularly where there is an institutional change (as, for example, with the then-Guangzhou Municipal Management of Bureau of Major Public Infrastructures, the procuring entity for the Asian Games Village, which was later merged into the Guangzhou Municipal Bureau of Agent Construction Projects).

The mapping ${ }^{387}$ covered three major new permanent sports venues, Guangzhou Cycling \& Skating and Maximal Exercise Centre (price unknown), Guangdong Olympic Aquatics Centre (43.357 million USD) ${ }^{388}$ and Guangdong Olympic Tennis Centre (28 million USD) ${ }^{389}$ plus the Asian Games Village ( 3.9705 billion USD), containing the athletes' accommodation and other facilities such as a media centre. ${ }^{390}$. Two bodies undertook the mapped procurement ${ }^{391}$, both permanent public bodies, namely the Guangzhou Administration Office of Major Public Construction Projects ${ }^{392}$, responsible for the Village and the Cycling and Skating Centre, and the Administration of Agent Construction Projects, Guangdong Province, in charge of the Aquatics and Tennis Centres. All the mapped infrastructure was subject to the (complex and fragmented ${ }^{393}$ ) Chinese regulatory framework for procurement, in particular the 1999 Tendering and Bidding Law $^{394}$ (which generally requires open public tenders, allowing restricted tendering in

\footnotetext{
${ }^{386}$ The material found when the document research was done in 2018 was no longer found in May 2019, for reasons that are not clear but may be due to updating.

38778 sports venues were constructed or renovated along with a venue for the opening and closing ceremonies, with a total investment of $1,134,565,680$ USD ( 7248000000 RMB). Apart from venues, construction work covered the Asian Games Village plus municipal infrastructure projects (transportation etc) (estimated cost of $17,055,775,000$ USD, accounting for $90 \%$ of the event total). See "The Result of the Guangzhou Asian Games Venues Audit Was Announced: Illegal Subcontracting Emerged in Eight Venue Construction Projects", People's Daily Online, November 26, 2011, available at http://politics.people.com.cn/GB/16397070.html (source in Chinese; authors' translation). See also "Adhering to the Principle of Thrift Saving In Running the Asian Games, The Total Investment Still Exceeds 120 Billion RMB", Titan Zhoubao, available at http://sports.titan24.com/other/2010-10-15/86890.html (source in Chinese; authors' translation).

388 See "The Provincial-level Project in 2010 Asian Games-Guangdong Olympic Aquatics Centre", released by Administration of Agent Construction Projects, Guangdong Province on its official website, available at http://djj.gd.gov.cn/service/intro/content/post 382062.html and http://www.tyj.gd.gov.cn/4294295/4308050.html (all figures converted to USD as at June 15, 2018) (source in Chinese; authors' translation).

${ }^{389}$ See "The Provincial-level Project in 2010 Asian Games- Guangdong Olympic Tennis Centre", released by Administration of Agent Construction Projects, Guangdong Province on its official website, available at http://djj.gd.gov.cn/service/intro/content/post_382061.html and http://www.tyj.gd.gov.cn/4294295/4308050.html (source in Chinese; authors' translation).

390 See "The 16 ${ }^{\text {th }}$ Asian Games, Guangzhou 2010", December 13, 2017, announcement by Asian Games Committee, Chinese text available at http://www.hangzhou2022.cn/yybk/yyls/201712/t20171213_664.shtml. ${ }^{391}$ Multiple bodies were involved in procurement for the Games in accordance with their remits: see Jingren Ouyang et al., "Analysis on the Construction Planning and Post-competition Utilization of Guangzhou Asian Games Venues", Social Science Research Project of the General Administration of Sport of China (2009) (source in Chinese; authors' translation).

392 Now merged into Guangzhou Municipal Bureau of Agent Construction Projects. Guangzhou Administration Office of Major Public Construction Projects was in charge of $60.8 \%$ of the infrastructures for the Games, accounting for $86.5 \%$ of the total investment in venues. See "RMB15 Billion Poured into Major Asian Games Projects", July 3, 2017, available at http://www.gz2010.cn/10/0703/14/6AM56SCM0078002U.html (source in Chinese; authors' translation).

393 See generally P. Wang, "Coverage of the WTO's Agreement on Government Procurement: Challenges of Integrating China and other Countries with a Large State Sector into the Global Trading System" (2007) 10 Journal of International Economic Law 887; P. Wang, "China's Evolving Legal Framework on Public Procurement" (2004) 13 P.P.L.R. 285; P. Wang, "Accession to the Agreement on Government Procurement: the Case of China", in S. Arrowsmith and R. Anderson (ed.), The WTO Regime on Government Procurement Recent Developments and Challenges Ahead (Cambridge: Cambridge University Press, 2011), Ch.3, pp.92-116.

394 Tendering and Bidding Law of the People's Republic of China [中华人民共和国招标投标法], promulgated on August 30, 1999, came into force on Jan. $1^{\text {st }}, 2000$, Chinese text available at http://www.npc.gov.cn/wxzl/gongbao/2000-12/05/content_5004749.htm. A peculiarity of China's 1999 Tendering and Bidding Law is that it regulates construction tendering by the private as well as public sector.
} 
limited case ${ }^{395}$ ) and related ministerial rules, along with applicable local rules (of Guangdong Province and Guangzhou Municipality).

All the mapped procurements adopted the Design and Build model, but with the design novated to the construction contractor(s $)^{396}$. No information was available on use or otherwise of private financing. There was little public information about planning, although there was evidence of feasibility studies for the Aquatics and Tennis Centres. ${ }^{397}$ For these two venues, evidence was found of cost-benefit analysis at the time of research (2018) but is no longer accessible. ${ }^{398}$ There was also generally little found on comprehensive risk management although it cannot be concluded that it did not occur. There was in fact evidence of a risk assessment for the Village ${ }^{399}$ and of engagement of private expertise for ongoing management of construction for the Aquatics Centre; and there was also information on post-award audit by the Guangzhou Municipal Fiscal Bureau on the use of funds in venues and urban construction ${ }^{400}$, which presumably covered the Village and Cycling and Skating Centres, as well as evidence of external audit relating to the Aquatics and Tennis Centres ${ }^{401}$.

As regards procurement procedure, the legal framework provides for tendering procedures in line with international standards and the piecemeal information online, including news reports and solicitations, shows open public tenders for the mapped procurements ${ }^{402}$. However, there was almost no further detail. While solicitation and award notices were published electronically, the procurements were generally paperbased.

There was also minimal public information on contract execution and the governance mechanisms, if any, are not clear. Evidence was found of amendments in the

\footnotetext{
${ }^{395}$ Restricted tendering under the Chinese 1999 Tendering and Bidding Law largely falls within the concept of restricted tendering as defined for this study, not requiring a public solicitation.

396 On the Asian Games Village, for instance see "Announcement of the Result of the 2010 (Guangzhou) Asian Games Village Planning and Design Competition" (source in Chinese; authors' translation), available at http://www.gzlpc.gov.cn/gzlpc/ywpd_cxgh_tzgg/200704/ef9d53a8b860476e818efdf752f3d6c3.shtml; on the Cycling \& Skating Centre, "Announcement on the List of Participants in the International Competition for the Architectural Design of the Guangzhou Cycling \& Skating Centre" (source in Chinese; authors' translation), text available at http://fszrzy.foshan.gov.cn/zwgk/cgxx/200712/t20071220_3020089.html. The information about the design for the Aquatics Centre and Tennis Centre was available on announcement by the Administration of Agent Construction, Guangdong Province, on its official website, which however is no longer accessible at the time of writing. The original webpages were accessible at http://www.gdsdjj.gov.cn/ViewMessage.aspx?ColumnId=10\&MessageId=105

397 See "Guangdong Provincial Development and Reform Commission Approved Feasibility Study for Aquatics Centre for 2010 Asian Games", available at http://drc.gd.gov.cn/xmgg/content/post_318270.html; and "Guangdong Provincial Development and Reform Commission Approved Feasibility Study for Tennis Centre for 2010 Asian Games", available at http://drc.gd.gov.cn/xmgg/content/post_836019.html (sources in Chinese; authors' translation).

${ }^{398}$ Information was found at http://www.gcpo.com.cn/chn201212061526227/(in Chinese).

399 The evidence of risk assessment was found on the public notice made by Guangzhou Administration Office of Major Public Construction Projects on its official website, which was available at http://www.gcpo.com.cn/chn201212061526227/ (in Chinese) but no longer accessible at the time of writing. 400 "Asian Games Venues Audit Found 448 Issues Regarding Failing to Use Open Tendering as Required", Jinyang Newspaper, February 27, 2013, at

http://sports.ifeng.com/zonghe/qita/detail_2013_02/27/22531046_0.shtml (source in Chinese; authors' translation).

${ }^{401}$ Information on external inspection for the Aquatics Centre can be found through public announcement by Administration of Agent Construction Projects, Guangdong Province on its official websites, for instance, available at http://djj.gd.gov.cn/news/job/content/post_382071.html; http://djj.gd.gov.cn/news/job/content/post_382143.html; http://djj.gd.gov.cn/news/job/content/post_382093.html (sources in Chinese). Information on external inspection activities on Guangdong Olympic Tennis Centre is available at http://djj.gd.gov.cn/service/intro/content/post_382061.html (in Chinese) 402 The evidence of open tendering in the procurement process can be found through several briefings made by Administration of Agent Construction Projects, Guangdong Province on its official websites on its official website, see the Briefing in September, available at http://djj.gd.gov.cn/public/count/content/post_382083.html; see also the Briefing in July, available at http://djj.gd.gov.cn/public/count/content/post_382076.html (all sources in Chinese).
} 
procurement of the Aquatics and Tennis Centres, ${ }^{403}$ but it is not known what rules and processes applied. Likewise there is almost no current information on reports on financial and physical process, although for the Tennis Centre updates on financial progress were found on the procuring entity's website. ${ }^{404}$

The Games was known for its significant budget overrun, criticised in the media ${ }^{405}$, but, interestingly, there was no official data on actual expenditure and, as indicated above, the cost of the Cycling and Skating Centre is unknown. Concerns had been raised in the Guangzhou People's Congress Standing Committee in 2009 on the lack of information on use of funds. ${ }^{406}$ It seems there were many irregularities: the Guangzhou Municipal Fiscal Bureau audit report on the infrastructure reportedly identified 448 procurement irregularities, including illegal subcontracting, failure to use open tendering, lack of feasibility analysis and absence of budgetary approval covering procurement planning, tendering and post-tendering stages ${ }^{407}$. There were also significant allegations of procurement corruption; thus according to a news report, from 2009 to 201016 corruption cases involving around 782,375 USD were investigated involving 12 personnel from government and state owned enterprises ${ }^{408}$, although no information could be found on the outcomes.

\subsection{Commonwealth Games, New Delhi, India, 2010}

A reasonable amount of information was available online for New Delhi, although with variation in detail for different procurements. The most important sources were the six Reports of the High Level Committee for the Games, ${ }^{409}$ the Post Games Report of the Organising Committee ${ }^{410}$ and Report No. 6 of 2011 by the Comptroller and Auditor General of India. ${ }^{411}$ The bid documents were not available at the time of the research (2018) and it is not known whether they were once published, but some excerpts were on the High Level Committee's website. ${ }^{412}$

Mapping covered 15 procurements relating to the renovation and/or construction of 12 venues, namely Jawaharlal Nehru Stadium, Thyagaraj Stadium, Chhattarsal Stadium,

403 See "Exploring A New Way to Prevent Corruption in the Field of Engineering Construction in Guangdong Province", (authors' translation), text in Chinese available at http://www.bjgtjz.com/newsview.asp?nid=5226. $404 \mathrm{http}: / /$ www.gdsdjj.gov.cn/Columns/MessageColumnMore. aspx?ColumnId=24.

${ }^{405}$ For example, see Hongqi Pan, "The NPC Supervision Has Been Dilatory" (authors' translation), Henan Business Newspaper, February 24, 2011, source available in Chinese at http://finance.ifeng.com/money/roll/20110224/3477156.shtml.

${ }^{406}$ According to Mr J. Deng, a Committee member: "No one is clear about how much the Asian Games would cost", and "there is not even a rough figure", and "Some said the budget was RMB 200 billion, but there is no official data as evidence" - in "Guangzhou Municipal People's Congress Demanded Publication of Expenditure for Asian Games: That Could Amount to 200 Billion RMB", December 16, 2009, Chinese text available at http://news.163.com/09/1216/21/5QMFIE6T0001124J.html (translation of quotes and reference details by Ke Ren).

407 The original title was "Report on the Research and Deliberations Regarding the Use of Funds for Venues and Urban Constructions in Asian Games and Asian Paralympics" (authors' translation). See "Asian Games Venues Audit Found 448 Issues Regarding Failing to Use Open Tendering as Required", Jinyang Newspaper, February 27, 2013, at http://sports.ifeng.com/zonghe/qita/detail_2013_02/27/22531046_0.shtml (source in Chinese; authors' translation); and "The Result of the Guangzhou Asian Games Venues Audit Was Announced: Illegal Subcontracting Emerged in Eight Venue Construction Projects", People's Daily Online, November 26, 2011, at http://politics.people.com.cn/GB/16397070.html (source in Chinese; authors' translation). At the time of writing the Audit report mentioned in the news release was not available on the Internet.

408 See Huihui Wei and Jiefeng Cui, "Panyu Municipality Investigated 15 Corruption Cases in Construction, 12 National Staff Involved in the Cases", Xinxishibao, August 17, 2010, at http://news.gz.fang.com/2010-08$17 / 3677585 . h t m$ (source in Chinese; authors' translation).

409 High Level Committee Commonwealth Games 2010's website available at https://archive.india.gov.in/high_level/reports.htm.

${ }^{410}$ Organising Committee Commonwealth Games 2010 Delhi, "Delhi 2010 Post Games Report" (Commonwealth Games Federation), available at https://thecgf.com/sites/default/files/2018-03/D2010-Post-Games-Report.pdf.

${ }^{411}$ Comptroller and Auditor General of India, "Audit Report on XIXth Commonwealth Games 2010 - Report No. 6 of 2011-12" (Comptroller and Auditor General of India, August 5, 2011), available via https://www.cag.gov.in/content/report-no-6-2011-\%E2\%80\%93-performance-audit-xixth-commonwealthgames.

412 High Level Committee Commonwealth Games 2010's website available at https://archive.india.gov.in/high_level/reports.htm. 
Delhi University Stadium, Delhi Public School, R.K. Puram, Yamuna Sports Complex, Major Dhyan Chand National Stadium, Dr. S.P. Mukherjee Swimming Pool Complex, Indira Gandhi Stadium Complex, Dr. Karni Singh Shooting Range, Shivaji Stadium and the Commonwealth Games Village. The venue procurements were selected based on their significance for each venue and accessibility of information, and accounted for about $20 \%$ in value of the sport-specific infrastructure. ${ }^{413}$ Multiple agencies were involved, the main procuring entities being the Central Public Works Department, New Delhi Municipal Council, Delhi Development Authority (which handled the Village), ${ }^{414}$, Government of National Capital Territory of Delhi, Delhi University, All India Tennis Association and Jamia Millia Islamia University. ${ }^{415}$ Most of the procuring entities were public but there were some limited procurements by bodies of a private nature, such as the All India Tennis Association. ${ }^{416}$ There were also various projects in Delhi relating to, for example, transport, utilities and tourist facilities ${ }^{417}$, with the main procuring entities here being the Public Works Department of the Government of National Capital Territory of Delhi, New Delhi Municipal Council, Delhi Development Authority, Municipal Corporation Delhi, Delhi Jal Board and Delhi Transport Corporation. ${ }^{418}$

India has no central legal procurement framework and different entities have their own rules, which other entities sometimes follow. The most widely used are those in the Manual of the Central Public Works Department, ${ }^{419}$ which was generally applied and referred to in procurements by that Department and the Public Works Department of the Government of National Capital Territory of Delhi. Reference was made to the Manual and also the General Conditions of Contract of the Central Public Works Department by the High Level Committee, which criticised the non-application or arbitrary application of their provisions, such as by including unlawful clauses for increased payments, ${ }^{420}$ failing to apply the standard financial criteria in the Manual so as to favour a certain bidder at pre-qualification stage ${ }^{421}$ and permitting unlawful sub-contracting. ${ }^{422}$ While there are rules and directives on procurement in the General Financial Rules $1963^{423}$ and

\footnotetext{
${ }^{413}$ Based on total tendered costs of the 15 mapped procurements taken from High Level Committee's Fourth Report and annexed bidding documents (where available) against the total approved venue budget stated in the Post Games Report. See: High Level Committee Commonwealth Games 2010, "Games Venues - Fourth Report of HLC" with annexures (High Level Committee, 2011), available via https://archive.india.gov.in/high_level/fourth_report.htm; Organising Committee Commonwealth Games 2010 Delhi, "Delhi 2010 Post Games Report" (Commonwealth Games Federation), pp.126-127, available at https://thecgf.com/sites/default/files/2018-03/D2010-Post-Games-Report.pdf.

414 On the Village, see High Level Committee Commonwealth Games 2010, "Commonwealth Games Village Second Report of HLC" with annexures (High Level Committee, 2011), available via https://archive.india.gov.in/high_level/second_report.htm.

${ }^{415}$ For details on responsibility of different agencies for Games venues see the tables in Organising Committee Commonwealth Games 2010 Delhi, "Delhi 2010 Post Games Report" (Commonwealth Games Federation), pp.123-125, available at https://thecgf.com/sites/default/files/2018-03/D2010-Post-Games-Report.pdf.

${ }^{416}$ There is no single formal division of entities into public and private in India.

${ }^{417}$ E.g. a new airport terminal, improvement of the Metro and upgrade of power distribution and water supply. See: High Level Committee Commonwealth Games 2010, "Report on City Infrastructure - Third Report of HLC", with annexures (High Level Committee, 2011), available via https://archive.india.gov.in/high_level/third_report.htm; Organising Committee Commonwealth Games 2010 Delhi, "Delhi 2010 Post Games Report" (Commonwealth Games Federation), pp. 161-167, available at https://thecgf.com/sites/default/files/2018-03/D2010-Post-Games-Report.pdf.

418 High Level Committee Commonwealth Games 2010, "Report on City Infrastructure - Third Report of HLC" (High Level Committee, 2011), pp. 10-15, available via https://archive.india.gov.in/high_level/third_report.htm.

419 Central Public Works Department, "CPWD Works Manual 2007" (Government of India), available at https://cpwd.gov.in/newsitem/latestnewspdf/Final-WorksManual.pdf. Note that at the time of the event, the 2007 version of the Manual was used. Revised version of the Manual was subsequently published in 2012, 2014 and 2019, all of which are available at https://cpwd.gov.in/Documents/cpwd_publication.aspx.

420 High Level Committee Commonwealth Games 2010, "Games Venues - Fourth Report of HLC" (High Level Committee, 2011), pp.35-36, available via https://archive.india.gov.in/high_level/fourth_report.htm.

${ }^{421}$ High Level Committee Commonwealth Games 2010, "Games Venues - Fourth Report of HLC" (High Level Committee, 2011), pp.50-51, available via https://archive.india.gov.in/high_level/fourth_report.htm.

422 High Level Committee Commonwealth Games 2010, "Games Venues - Fourth Report of HLC" (High Level Committee, 2011), p.57, available via https://archive.india.gov.in/high_level/fourth_report.htm.

${ }^{423}$ Amended in 2005 and after the Games in 2017.
} 
Delegation of Financial Powers Rules 1978, none of the sources examined referred to them.

Planning was problematic and the Audit report criticised the planning phase for not following the four-phase approach in India's bid for the event. ${ }^{424}$ For 12 of the 15 procurements, M/s Events Knowledge Service was appointed to prepare venue briefs ${ }^{425}$ (translated to detailed designs by the venue owners/implementing agencies). ${ }^{426}$ It was appointed simply by endorsement by the Commonwealth Games Federation, with which it had close ties 427 , but the appointment process took two and a half years, a period during which little other Games preparation took place. ${ }^{428}$ Further, the fact that Consultancy Engineering Services was appointed - by tender ${ }^{429}$ - as design consultant for all five main venues ${ }^{430}$ was found questionable in the Audit Report, which also mentions evidence of favouritism in the tendering processes. ${ }^{431}$ Later approval of the specifications and designs also suffered significant delay. ${ }^{432}$ However, there was evidence of advance notices published for 13 of the mapped procurements.

There was little published information on risk management, including of integrity risks. Although this was in theory a task of the Organising Committee, ${ }^{433}$ it was found that this

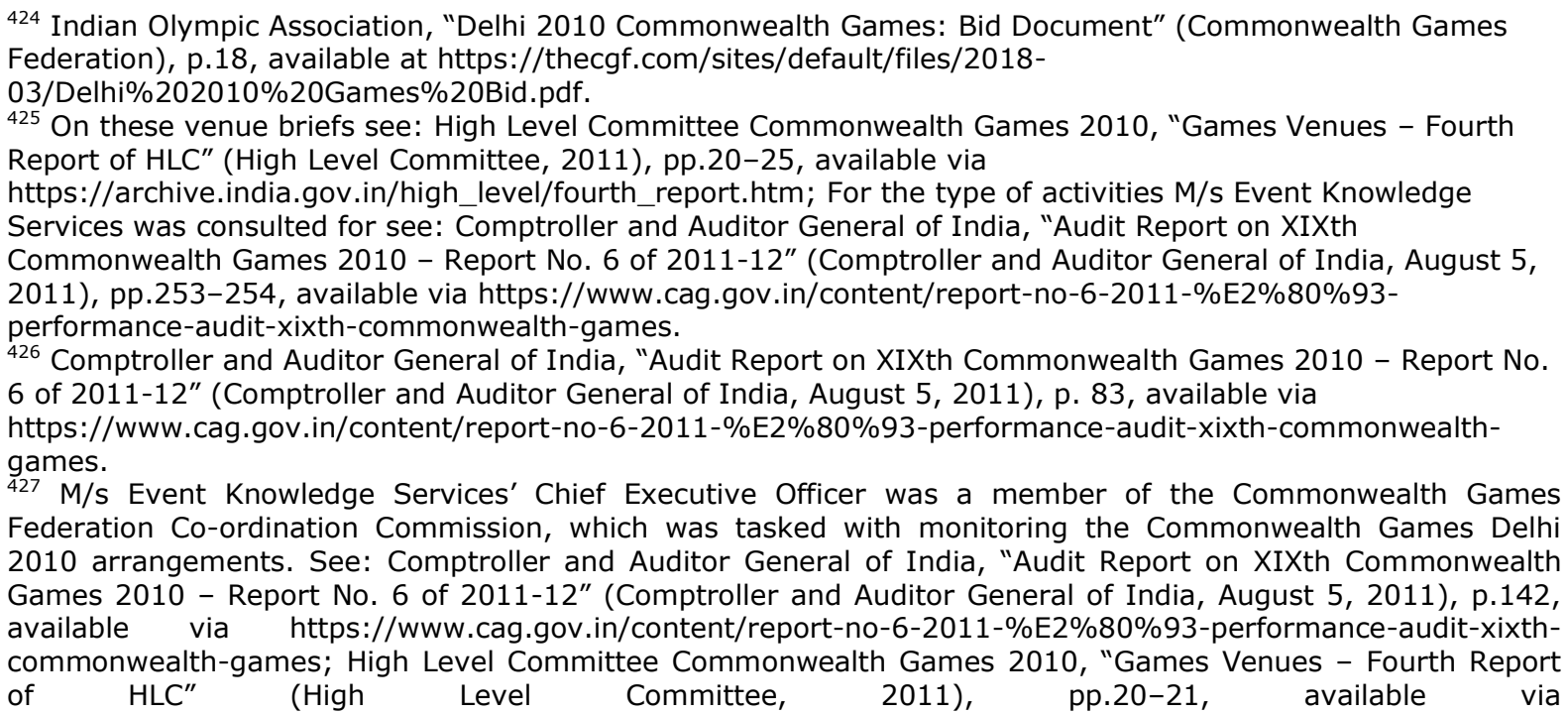
https://archive.india.gov.in/high_level/fourth_report.htm.

428 For a timeline of preparation activities see: Comptroller and Auditor General of India, "Audit Report on XIXth Commonwealth Games 2010 - Report No. 6 of 2011-12" (Comptroller and Auditor General of India, August 5, 2011), p.81, available via https://www.cag.gov.in/content/report-no-6-2011-\%E2\%80\%93-performanceaudit-xixth-commonwealth-games; High Level Committee Commonwealth Games 2010, "Games Venues Fourth Report of HLC" (High Level Committee, 2011), pp.20-21, available via

https://archive.india.gov.in/high_level/fourth_report.htm.

${ }^{429}$ For information on tendering processes and participating bidders see: Comptroller and Auditor General of India, "Audit Report on XIXth Commonwealth Games 2010 - Report No. 6 of 2011-12" (Comptroller and Auditor General of India, August 5, 2011), pp.256-257, available via https://www.cag.gov.in/content/reportno-6-2011-\%E2\%80\%93-performance-audit-xixth-commonwealth-games.

430 Comptroller and Auditor General of India, "Audit Report on XIXth Commonwealth Games 2010 - Report No. 6 of 2011-12" (Comptroller and Auditor General of India, $5^{\text {th }}$ August, 2011), p.256, available via https://www.cag.gov.in/content/report-no-6-2011-\%E2\%80\%93-performance-audit-xixth-commonwealthgames.

${ }^{431}$ Comptroller and Auditor General of India, "Audit Report on XIXth Commonwealth Games 2010 - Report No. 6 of 2011-12" (Comptroller and Auditor General of India, August 5, 2011), pp.258-261, available via https://www.cag.gov.in/content/report-no-6-2011-\%E2\%80\%93-performance-audit-xixth-commonwealthgames.

${ }_{432}$ The two key planning documents for the Games, namely the General Organisational Plan (GOP) and the Games Master Schedule (GMS), were approved only in August 2007 and November 2008 respectively Comptroller and Auditor General of India, "Audit Report on XIXth Commonwealth Games 2010 - Report No. 6 of 2011-12" (Comptroller and Auditor General of India, August 5, 2011), pp.81-84, available via https://www.cag.gov.in/content/report-no-6-2011-\%E2\%80\%93-performance-audit-xixth-commonwealthgames.

${ }_{433}$ Comptroller and Auditor General of India, "Audit Report on XIXth Commonwealth Games 2010 - Report No. 6 of 2011-12" (Comptroller and Auditor General of India, August 5, 2011), pp.99-104, available via 
only entailed ensuring insurance cover. ${ }^{434}$ However, there was at least a Study Report, Preparedness for the XIX Commonwealth Games $2010^{435}$ published by the Comptroller and Auditor General in July 2009 (about 15 months before the Games) to aid the Executive in 'monitoring and benchmarking progress', including on infrastructure.

The 2011 Audit Report described the Organising Committee's internal control framework as 'inadequate and ineffective' for reasons including irregular distribution of work (making it hard to establish the trail of decision making and accountability), inadequate/no documentation (casting doubt on the records' authenticity and/or their completeness) and inadequate legal vetting of documents, and it refers to internal audit and "vigilance" work - which refers to anti-corruption activity - being initiated only in 2010.436

All 15 mapped procurements were conducted by open public tender with prequalification. Nine involved post-tender negotiations to reduce price, all successful, and all award criteria that could be found were limited to price. Other procurement methods were sometimes used for the non-mapped procurements, including many direct awards grounded on urgency. Of the contracts scrutinised by the Comptroller and Auditor General of India, 107, worth about 50 million USD were awarded without tendering; 28, worth about 55 million USD, were awarded based on a single tender (a notable example being the Village contracts ${ }^{437}$ ) - and in many such cases, all vendors except one were rejected on sometimes questionable grounds; and 14, worth about 200 million USD, were awarded to vendors not fulfilling eligibility criteria. ${ }^{438}$ All the procurements studied were mainly paper-based, although whether there was some limited electronic communication is not known. No information was publicly available about the execution of the mapped procurements or on challenges.

The event's original bid budget was about 185 million USD but the budget estimate as of October 2010 had risen to more than fifteen times that ${ }^{439}$ and some reports speculate that the final cost was even higher. ${ }^{440}$ There were many quality problems. ${ }^{441}$ Two

https://www.cag.gov.in/content/report-no-6-2011-\%E2\%80\%93-performance-audit-xixth-commonwealthgames.

${ }_{434}$ Comptroller and Auditor General of India, "Audit Report on XIXth Commonwealth Games 2010 - Report No. 6 of 2011-12" (Comptroller and Auditor General of India, August 5, 2011), pp.234-235, available via https://www.cag.gov.in/content/report-no-6-2011-\%E2\%80\%93-performance-audit-xixth-commonwealthgames; the Central Public Works Department published a report on some of its procurement projects but apparently only post-event: see "Note on Projects Related to Commonwealth Games (CWG)" (Central Public Works Department), at

http://cpwd.gov.in/GeneralCircularPdf/Common\%20Wealth\%20Games\%20Related.pdf.

435 The full report could not be found online but a summary is found as Annexe 2.1 in Comptroller and Auditor General of India, "Audit Report on XIXth Commonwealth Games 2010 - Report No. 6 of 2011-12" (Comptroller and Auditor General of India, August 5, 2011), pp.575-576, available via

https://www.cag.gov.in/content/report-no-6-2011-\%E2\%80\%93-performance-audit-xixth-commonwealthgames.

${ }^{436}$ Comptroller and Auditor General of India, "Audit Report on XIXth Commonwealth Games 2010 - Report No. 6 of 2011-12" (Comptroller and Auditor General of India, $5^{\text {th }}$ August, 2011), pp.106-110, available via https://www.cag.gov.in/content/report-no-6-2011-\%E2\%80\%93-performance-audit-xixth-commonwealthgames.

437 See: High Level Committee Commonwealth Games 2010, "Commonwealth Games Village - Second Report of HLC" Commonwealth Games Village (High Level Committee, 2011), pp.24-25, available via https://archive.india.gov.in/high_level/second_report.htm.

438 Comptroller and Auditor General of India, "Audit Report on XIXth Commonwealth Games 2010 - Report No. 6 of 2011-12" (Comptroller and Auditor General of India, August 5, 2011), p.112, available via https://www.cag.gov.in/content/report-no-6-2011-\%E2\%80\%93-performance-audit-xixth-commonwealthgames; also see Annexe 7.3 for detail of the irregularities.

439 Comptroller and Auditor General of India, "Audit Report on XIXth Commonwealth Games 2010 - Report No. 6 of 2011-12" (Comptroller and Auditor General of India, August 5, 2011), pp.86-87, available via https://www.cag.gov.in/content/report-no-6-2011-\%E2\%80\%93-performance-audit-xixth-commonwealthgames.

440 "Commonwealth Games 2010: The ballooning budget", NDTV, April 7, 2010, at

https://www.ndtv.com/sports-news/commonwealth-games-2010-the-ballooning-budget-414670; N.T. Mehta, "Games makeover is a Rs 66,550 cr bomb", India Today, August 27, 2010, at

https://www.indiatoday.in/sports/commonwealth-games-2010/story/games-makeover-is-a-rs-66550-cr-bomb81012-2010-08-27. 
examples receiving media attention (not related to the mapped procurements) were the collapse of the table-tennis court roof at the Yamuna Sports Complex just months after its inauguration ${ }^{442}$ and collapse of the footbridge next to Jawaharlal Nehru Stadium with injuries to 23 people, less than a month prior to the Games. ${ }^{443}$ Delay in delivery was also common, with the Audit Report and High Level Committee Report mentioning extensive delays from the late preparation and execution of many contracts. Of the nine mapped procurements for which the completion date was known none was completed on schedule, with the Jawaharlal Nehru Stadium's new weightlifting auditorium being 16 months late. 444

All the mapped procurements were the subject of allegations of integrity problems - one in the pre-tendering stage, 11 in the tendering stage and seven at post-award stage. ${ }^{445}$ They included manipulation of pre-qualification procedures to restrict competition in five cases ${ }^{446}$ favouritism in evaluation in nine cases $^{447}$ with one instance leading to an award to an ineligible bidder, ${ }^{448}$ excessive payment in 13 cases $^{449}$ and misrepresenting costs for tax reduction in one case. ${ }^{450}$

Outside the mapped procurements, there were several arrests for forgery and fraud, ${ }^{451}$ and, according to India's Central Vigilance Commission, more than $£ 1$ billion was defrauded from the Games' budget. ${ }^{452}$ There were many corruption allegations, ${ }^{453}$ often involving inflated prices, one high-profile instance being the arrest ${ }^{454}$ of Suresh Kalmadi,

441 "Commonwealth Games: Corruption, chaos \& amp; a race to avert a crisis", The Independent, August 19, 2010, at https://www.independent.co.uk/sport/general/others/commonwealth-games-corruption-chaos-ampa-race-to-avert-a-crisis-2057234.html; D. Bond, "Delhi learning downside of hosting games", September 22, 2010, BBC (blog), at http://www.bbc.co.uk/blogs/davidbond/2010/09/delhi_learning_downside_of_hos.html; S.K. Chakrabarti, "Will India be Ready to Host the Commonwealth Games?", Time, July 31, 2010, at http://content.time.com/time/world/article/0,8599,2007643,00.html.

442 R. Banerjee, "Yamuna complex shows a dismal picture", The Times of India, July 31, 2010, at https://timesofindia.indiatimes.com/news/Yamuna-complex-shows-a-dismal-picture/articleshow/6239115.cms. ${ }^{443}$ R. Bedi, "Commonwealth Games in chaos as 23 injured in stadium footbridge collapse", The Telegraph, September 21, 2010, at

https://www.telegraph.co.uk/sport/othersports/commonwealthgames/8016046/Commonwealth-Games-2010in-chaos-as-23-injured-in-stadium-foot-bridge-collapse.html.

${ }^{444}$ Comptroller and Auditor General of India, "Audit Report on XIXth Commonwealth Games 2010 - Report No. 6 of 2011-12" (Comptroller and Auditor General of India, August 5, 2011), Annexe 16.4 at pp. 686-693, available via https://www.cag.gov.in/content/report-no-6-2011-\%E2\%80\%93-performance-audit-xixthcommonwealth-games.

${ }^{445}$ High Level Committee Commonwealth Games 2010, "Games Venues - Fourth Report of HLC" (High Level Committee, 2011), available via https://archive.india.gov.in/high_level/fourth_report.htm; Comptroller and Auditor General of India, "Audit Report on XIXth Commonwealth Games 2010 - Report No. 6 of 2011-12" (Comptroller and Auditor General of India, August 5, 2011), available via

https://www.cag.gov.in/content/report-no-6-2011-\%E2\%80\%93-performance-audit-xixth-commonwealthgames.

${ }_{446}$ High Level Committee Commonwealth Games 2010, "Games Venues - Fourth Report of HLC" (High Level Committee, 2011), pp.32-33, 50, 81, 113-121, 127, 130, 342, available via

https://archive.india.gov.in/high_level/fourth_report.htm.

447 High Level Committee Commonwealth Games 2010, "Games Venues - Fourth Report of HLC" (High Level Committee, 2011), pp.67-71, 81, 84, 88, 113-121, 127, 130, available via

https://archive.india.gov.in/high_level/fourth_report.htm.

448 High Level Committee Commonwealth Games 2010, "Games Venues - Fourth Report of HLC" (High Level Committee, 2011), pp.127\&130, available via https://archive.india.gov.in/high_level/fourth_report.htm.

${ }^{449}$ High Level Committee Commonwealth Games 2010, "Games Venues - Fourth Report of HLC" (High Level Committee, 2011), pp.41-44, 67-71, 81, 84, 88, 106-108, 119, 142, available via

https://archive.india.gov.in/high_level/fourth_report.htm.

${ }^{450}$ High Level Committee Commonwealth Games 2010, "Games Venues - Fourth Report of HLC" (High Level Committee, 2011), pp.54-58, available via https://archive.india.gov.in/high_level/fourth_report.htm.

${ }^{451}$ D. Noble, "Take a stand" (2011) 16:4 Supply Management 27.

452 D. Noble, "Take a stand" (2011) 16:4 Supply Management 27.

453 S.K. Chakrabarti, "Will India be Ready to Host the Commonwealth Games?", Time, July 31, 2010, at http://content.time.com/time/world/article/0,8599,2007643,00.html.

454 "Top 10 facts about Kalmadi's Commonwealth Games scandal", NDTV, January 19, 2012, at https://www.ndtv.com/india-news/top-10-facts-about-kalmadis-commonwealth-games-scandal-568261; The "Commonwealth Games Scam", Times of India, December 17, 2016, at https://timesofindia.indiatimes.com/miscellaneous/commonwealth-games-scam/articleshow/56032112.cms; Transparency International, Global Corruption Report: Sport (Abingdon: Routledge, 2016), available via https://www.transparency.org/whatwedo/publication/global_corruption_report_sport. 
Chairman of the Organizing Committee along with nine other officials. ${ }^{455}$ According to a 2013 article, the Central Vigilance Commission along with the Central Bureau of Investigation was at that time working on 51 alleged corruption cases ${ }^{456}$ and there were also allegations of serious tax evasion by both public and private bodies relating to the event's projects. ${ }^{457}$

Clearly there were issues with the procurement that created both integrity and other risks, although how far these contributed to the substantive procurement failures cannot be assessed here. There was evidence that many contract awards did not fully comply with applicable rules, such as those of the Central Public Work Department Manual ${ }^{458}$ and General Conditions of Contract, ${ }^{459}$ as well as of other substantial irregularities. ${ }^{460}$ One of the most problematic issues was the delay in planning and starting the procurements, as discussed earlier, leading to short timelines and 'an artificial or consciously created sense of urgency. ${ }^{461}$ In a sample of 458 contracts studied by the Comptroller and Auditor General of India, 428 , accounting for $82 \%$ of the value of those contracts were finalised only in 2010. ${ }^{462}$ The Audit Report of Comptroller and Auditor General of India states:

'The argument of urgency was used to obviate the regular process of tendering for award of contracts. We found numerous instances of single tendering, award on "nomination basis", award of contracts to ineligible vendors, inconsistent use of restrictive Pre-Qualification (PQ) conditions to limit competition to favour particular vendors, inadequate time for bidding, cancellation and re-tendering of contracts, and inexplicable delays in contract finalization, all of which seriously compromised transparency and economy. ${ }^{463}$

Citing urgency, the application of certain procurement procedures was waived by the government and/or implementing agencies, including those relating to restrictive clauses

\footnotetext{
455 "CWG scam: Court to frame charges against Kalmadi, 9 others", News18, February 4, 2013, at https://www.news18.com/news/politics/cwg-mess-tsr-backgrounder-588636.html.

456 "Central Vigilance Commission closes 10 corruption cases in Commonwealth Games projects", Daily News and Analysis, October 11, 2013, at http://www.dnaindia.com/india/report-central-vigilance-commission-closes10-corruption-cases-in-commonwealth-games-projects-1902284.

457 "CWG scam: CVC declines to share details of scam probe", The Indian Express, October 11, 2016, at http://indianexpress.com/article/india/india-news-india/cwg-scam-cvc-declines-to-share-details-of-scamprobe-3076583/.

${ }_{458}$ For some examples see: High Level Committee Commonwealth Games 2010, "Games Venues - Fourth Report of HLC" (High Level Committee, 2011), pp.35-36, 50-51, 57, 115, 188, 207, 228, 241, available via https://archive.india.gov.in/high_level/fourth_report.htm.

${ }^{459}$ For some examples see: High Level Committee Commonwealth Games 2010, "Games Venues - Fourth Report of HLC" (High Level Committee, 2011), pp.36, 116-117, 187-188, 270, available via https://archive.india.gov.in/high_level/fourth_report.htm.

460 Comptroller and Auditor General of India, "Audit Report on XIXth Commonwealth Games 2010 - Report No. 6 of 2011-12" (Comptroller and Auditor General of India, August 5, 2011), pp.112-114 and Annexe 7.3, available via https://www.cag.gov.in/content/report-no-6-2011-\%E2\%80\%93-performance-audit-xixthcommonwealth-games.

${ }^{461}$ Comptroller and Auditor General of India, "Audit Report on XIXth Commonwealth Games 2010 - Report No. 6 of 2011-12" (Comptroller and Auditor General of India, August 5, 2011), p.563, available via https://www.cag.gov.in/content/report-no-6-2011-\%E2\%80\%93-performance-audit-xixth-commonwealthgames.

462 Comptroller and Auditor General of India, "Audit Report on XIXth Commonwealth Games 2010 - Report No. 6 of 2011-12" (Comptroller and Auditor General of India, August 5, 2011), p.111, available via https://www.cag.gov.in/content/report-no-6-2011-\%E2\%80\%93-performance-audit-xixth-commonwealthgames.

${ }_{463}$ Comptroller and Auditor General of India, "Audit Report on XIXth Commonwealth Games 2010 - Report No. 6 of 2011-12" (Comptroller and Auditor General of India, August 5, 2011), p.9, available via https://www.cag.gov.in/content/report-no-6-2011-\%E2\%80\%93-performance-audit-xixth-commonwealthgames.
} 
(such as earnest money deposit requirements, bank guarantees and warranty periods ${ }^{464}$ ) and inspection of material prior to dispatch. ${ }^{465}$

\subsection{Commonwealth Games, Gold Coast, Australia, 2018}

The body responsible for planning, organising and delivering this event was the Gold Coast 2018 Commonwealth Games Corporation (GOLDOC), established under the Commonwealth Games Arrangements Act 2011 in January 2012 specifically to plan, organise and deliver the Games, and dissolved in December $2018^{466}$. It is a not for profit body corporate and a statutory body for the purposes of the Financial Accountability Act 2009 and Statutory Bodies Financial Arrangements Act 1982 (which cover various bodies of a public nature) meaning that it was subject to all relevant Queensland Government procurement policies ${ }^{467}$ when conducting procurement activities for the Games.

Its "Games Delivery Partners"468 were the Queensland Government's Office of the Commonwealth Games (OCG), an office within the Department of Tourism, Major Events, Small Business and the Commonwealth Games, which was first advisor to the State Government on its investment in the Games and capital budget management; City of Gold Coast (CGC), responsible for most city operations relating to the event and for the city legacy, and which now owns many of the venue assets; the Australian Government, which provided, for example, services relating to customs, bio-security, tourism and communications, and national security; and Commonwealth Games Australia (CGAus), the overall national controlling body responsible for operations, publicity and development.

These Games were hosted across 18 facilities, located on the Gold Coast, and in Brisbane, Cairns and Townsville. Three new venues were provided and a further seven had major upgrades, with the overall infrastructure program totalling AUDUSD320 million.

The procurements mapped related to four sport venues, namely the Queensland State Velodrome (new), Nerang Mountain Bike Trails (upgrade), Carrara Stadium(upgrade) and Gold Coast Aquatics Centre (upgrade) ${ }^{469}$. The mapping covered 7 procurement exercises covering all the substantial construction for these venues.

\footnotetext{
${ }^{464}$ Comptroller and Auditor General of India, "Audit Report on XIXth Commonwealth Games 2010 - Report No. 6 of 2011-12" (Comptroller and Auditor General of India, August 5, 2011), p.552, available via https://www.cag.gov.in/content/report-no-6-2011-\%E2\%80\%93-performance-audit-xixth-commonwealthgames.

465 Comptroller and Auditor General of India, "Audit Report on XIXth Commonwealth Games 2010 - Report No. 6 of 2011-12" (Comptroller and Auditor General of India, August 5, 2011), p.379, available via https://www.cag.gov.in/content/report-no-6-2011-\%E2\%80\%93-performance-audit-xixth-commonwealthgames.

${ }^{466}$ With remaining assets or liabilities to be transferred to the Queensland Government at that point: Gold Coast 2018 Commonwealth Games Corporation, "Annual Report 2017 - 2018: Financial Statements 2017 2018" (Gold Coast 2018 Commonwealth Games Corporation, 2018), p.9, available at https://gc2018.com/sites/default/files/2018-10/GOLDOC-Annual-Report-2017-2018.pdf.

${ }^{467}$ For example, Queensland Government Chief Procurement Office, Department of Public Works, "State Procurement Policy: better Procurement, better Outcomes" (Queensland Government, Department of Public Works, September 2010) available at

https://www.energex.com.au/_data/assets/pdf_file/0007/343951/State-Procurement-Policy-2010.pdf; Queensland Government, Department of Housing and Public Works, "Queensland Procurement Policy" (Queensland Government, Department of Housing and Public Works, June 2013), available at https://www.cabinet.qld.gov.au/documents/2013/Jun/Procurement/Attachments/Attachment\%20\%20Queensland\%20Procurement\%20Policy\%202013.PDF; and "Forward Procurement Plan for the 2018 Gold Coast Commonwealth Games" (Queensland Government, 2014).

468 Gold Coast 2018 Commonwealth Games Corporation, "Annual Report 2017 - 2018" (Gold Coast 2018 Commonwealth Games Corporation, 2018), pp.10-11, available at https://gc2018.com/sites/default/files/2018-10/GOLDOC-Annual-Report-2017-2018.pdf. 469 State of Queensland, "Gold Coast 2018 Commonwealth Games Post Games Report" (State of Queensland, 2019), p.272, available via https://publications.qld.gov.au/dataset/gold-coast-2018-commonwealth-gamespost-games-report.
} 
As with many other events, there was no detailed information available at the time of the research on risk management or execution. However, this seems unlikely to indicate an absence of risk management activity: there were requirements on this under the relevant Games Policies discussed later, and such requirements are generally strictly followed in Queensland government procurements (using a risk management approach based on ISO31000) ${ }^{470}$. Documents on this are normally internal documents only, so would not be expected to be found in public information. As regards execution, significant amendments (about USD 8000 or more) were required to be published ${ }^{471}-a$ requirement generally followed strictly in Queensland - and would thus have been publicly available at the time made (although no longer publicly available).

There was no evidence of use of private finance for the sport venues mapped for this project.

The Queensland government has expressed a strong policy commitment to transparency in procurement information, including the period of infrastructure procurement for this event ${ }^{472}$ and to electronic procurement (see below). The principal information sources used were GOLDOC's Annual Reports to the Queensland Parliament ${ }^{473}$, including a postgames report ${ }^{474}$; the awarded contracts portal of the Queensland Government (QTenders) ${ }^{475}$; the details for each venue from the (now archived) "Embracing 2018" website ${ }^{476}$; and fact sheets for each of the venues under examination located in Ahead of the Games publications ${ }^{477}$, all available electronically. All procurement documents are available to download free of charge from QTenders at the time of the procurement but although their existence remains listed on the site - they cannot be viewed or downloaded after the tender deadline ${ }^{478}$.

It appears that the procurement activities for the venue infrastructure were conducted primarily through the Department of State Development, Manufacturing, Infrastructure

\footnotetext{
470 See https://www.treasury.qld.gov.au/resource/guide-risk-management/, which encourages use of ISO31000; https://www.forgov.qld.gov.au/risk-management-and-internal-controls, which outlines the expectation that public officials will understand and manage risks associated with achieving business objectives; and Queensland Government, Department of Housing and Public Works, "Queensland Procurement Policy" (Queensland Government, Department of Housing and Public Works, June 2013), Principle 5, p.8, which requires risk to be included in significant procurement plans (available at https://www.cabinet.qld.gov.au/documents/2013/Jun/Procurement/Attachments/Attachment\%20\%20Queensland\%20Procurement\%20Policy\%202013.PDF).

471 Office of the Chief Advisor - Procurement, "Procurement guidelines: Contract disclosure", Version 3.0 (The State of Queensland, Department of Housing and Public Works, May 2019), p.9, available at https://www.hpw.qld.gov.au/SiteCollectionDocuments/ProcurementGuideContractDisclosure.pdf; and predecessor versions referred to in Queensland Government, Department of Housing and Public Works, "Queensland Procurement Policy" (Queensland Government, Department of Housing and Public Works, June 2013), p.9, available at

https://www.cabinet.qld.gov.au/documents/2013/Jun/Procurement/Attachments/Attachment\%20\%20Queensland\%20Procurement\%20Policy\%202013.PDF.

472 Queensland Government Chief Procurement Office, Department of Public Works, "State Procurement Policy: better Procurement, better Outcomes" (Queensland Government, Department of Public Works, September 2010), p.5, available at https://www.energex.com.au/_data/assets/pdf_file/0007/343951/StateProcurement-Policy-2010.pdf; Queensland Government, Department of Housing and Public Works, "Queensland Procurement Policy" (Queensland Government, Department of Housing and Public Works, June 2013), p.9, available at

https://www.cabinet.qld.gov.au/documents/2013/Jun/Procurement/Attachments/Attachment\%20\%20Queensland\%20Procurement\%20Policy\%202013.PDF.

${ }^{473}$ Available via https://publications.qld.gov.au/dataset/annual-report-gold-coast-2018-commonwealth-gamescorporation-goldoc.

474 State of Queensland, "Gold Coast 2018 Commonwealth Games Post Games Report" (State of Queensland, 2019), available via https://publications.qld.gov.au/dataset/gold-coast-2018-commonwealth-games-postgames-report.

475 https://www.hpw.qld.gov.au/qtenders/.

476 It can be accessed at the National Library of Australia, at http://pandora.nla.gov.au/pan/146667/20190115-0215/www.embracing2018.com/index.html.

477 Queensland Government, "Ahead of the Games: Evaluation Report for the Gold Coast 2018 Commonwealth Games Legacy Program", Edition 5 November 2017 (Queensland Government, 2017), pp.13-26.

${ }^{478}$ While they can be requested under the Right to Information Act 2009, applications take significant time to finalise, as well as incurring an application fee of USDUSD37.80 plus cost-recovery charges.
} 
and Planning (DSDMIP) through the Major Projects Office ${ }^{479}$ (whereas goods and nonconstruction services procurement relating to the venues (not mapped for this study) was predominantly undertaken by GOLDOC) ${ }^{480}$.

Legislation and policy at the Commonwealth (national) level do not generally apply to State procurement, and Queensland has no specific State procurement legislation (although there is legislation on certain relevant matters such as financial management and freedom of information) ${ }^{481}$; instead procurement policies are set by administrative means. The State Procurement Policy September $2010^{482}$ (SPP) which was replaced by the Queensland Procurement Policy June $2013^{483}$ (QPP), and the Queensland Charter of Local Content, provided the overarching direction and principles for Games procurement. The SPP articulated three core principles of advancing the priorities of the Government, value for money, and Probity and accountability for outcomes, while the QPP articlated six: value for money (stated as primary ${ }^{484}$ ); working across agency boundaries to achieve savings and benefits; leaders in procurement practice; advancing government objectives; stakeholder and community confidence; and procurement integrity with accountabilityfor outcomes. There is provision for use open procurement processes wherever possible and limited processes must not be used for the purposes of avoiding competition ${ }^{485}$; and entities must ensure that there is a complaints management mechanism for complaints relating to the award procedure ${ }^{486}$.

Also applicable was the specific Forward Procurement Plan for the Gold Coast Commonwealth Games 2018 (FPP), the primary purpose of which was to inform potential suppliers of opportunities, but which also aimed to provide a consistent overview of procurement activities at a whole-of-government level and outline procurement probity requirements. The document expressly applied to procurement undertaken by GOLDOC,

479 Queensland Government, Department of State Development, Manufacturing, Infrastructure and Planning, http://www.dsdmip.qld.gov.au/infrastructure-and-planning/planning/major-projects.html; see Gold Coast 2018 Commonwealth Games Corporation, "Annual Report 2017 - 2018: Financial Statements 2017 - 2018" (Gold Coast 2018 Commonwealth Games Corporation, 2018), p.9, available at

https://gc2018.com/sites/default/files/2018-10/GOLDOC-Annual-Report-2017-2018.pdf, and Gold Coast 2018 Commonwealth Games Corporation, "Annual Report 2012-13" (Gold Coast 2018 Commonwealth Games Corporation, 2013), p.11, available at https://gc2018.com/sites/default/files/2017-09/Annual-Report2013.pdf. It was not possible to verify this in time for each individual procurement, however, because of difficulties accessing the documentation.

${ }^{480}$ A search on QTenders for procurements conducted by GOLDOC yielded 40 results, covering goods and nonconstruction services. See for example procurements for accreditation and secure materials at

https://www.hpw.qld.gov.au/qtenders/tender/display/tender-details.do?id=18329; bulk fuel and fuel cards at https://www.hpw.qld.gov.au/qtenders/tender/display/tender-details.do?id=21310; and data cabling at https://www.hpw.qld.gov.au/qtenders/tender/display/tender-details.do?id=19463.

${ }^{481}$ For example, Financial Accountability Act (Queensland) 2009; Financial and Performance Management Standard (Queensland) 2009; Public Sector Ethics Act (Queensland) 1994; Right to Information Act (Queensland) 2009; and Public Interest Disclosure Act (Queensland) 2010.

482 Queensland Government Chief Procurement Office, Department of Public Works, "State Procurement Policy: better Procurement, better Outcomes" (Queensland Government, Department of Public Works, September 2010) available at https://www.energex.com.au/_data/assets/pdf_file/0007/343951/State-ProcurementPolicy-2010.pdf.

${ }^{483}$ Queensland Government, Department of Housing and Public Works, "Queensland Procurement Policy" (Queensland Government, Department of Housing and Public Works, June 2013), available at https://www.cabinet.qld.gov.au/documents/2013/Jun/Procurement/Attachments/Attachment\%20\%20Queensland\%20Procurement\%20Policy\%202013.PDF.

${ }^{484}$ Queensland Government, Department of Housing and Public Works, "Queensland Procurement Policy" (Queensland Government, Department of Housing and Public Works, June 2013), p.3, available at https://www.cabinet.qld.gov.au/documents/2013/Jun/Procurement/Attachments/Attachment\%20\%20Queensland\%20Procurement\%20Policy\%202013.PDF.

${ }^{485}$ Queensland Government Chief Procurement Office, Department of Public Works, "State Procurement Policy: better Procurement, better Outcomes" (Queensland Government, Department of Public Works, September 2010), p.8, available at https://www.energex.com.au/_data/assets/pdf_file/0007/343951/StateProcurement-Policy-2010.pdf.

${ }^{486}$ Queensland Government, Department of Housing and Public Works, "Queensland Procurement Policy" (Queensland Government, Department of Housing and Public Works, June 2013), p.9, available at https://www.cabinet.qld.gov.au/documents/2013/Jun/Procurement/Attachments/Attachment\%20\%20Queensland\%20Procurement\%20Policy\%202013.PDF. 
budget funded Queensland state Government agencies, and statutory authorities and bodies. It was open to local governments, such as the City of Gold Coast, to undertake their procurements in accordance with the FPP, at their discretion.

Both the $\mathrm{SPP}^{487}$ and the $\mathrm{QPP}^{488}$ required the use of electronic means for notices and provision of documents on-line and, as noted above, the existence of these documents was indicated in QTenders. The extent of use of electronic tendering for the mapped projects is not known.

Of the 7 mapped infrastructure procurements, four, including the most significant (main sport precinct, velodrome construction and aquatics facility) were done by inviting all qualified suppliers from all those registered on an advertised and continuously accessible list but (so far as can be established) without any individual public solicitation for the procurements that might have alerted non-registered firms to seek to register ${ }^{489}$. This approach which we suggested can be considered an open public tender but a qualified one ${ }^{490}$, in view of the possible impact of limiting access to already-registered suppliers and the absence of a specific public solicitation. The other procurements mapped were very small procurements using a restricted tender ${ }^{491}$.

No actual or alleged integrity issues were uncovered. Sporting venues were available well ahead of the event ensuring that they were used and tested beforehand. ${ }^{492}$ The main controversy seems to have been the decision not to include a roof on the aquatics centre ${ }^{493}$. The sport venues overall appear to have been delivered with a negligible USDUSD783,000 overrun from the amount budgeted ${ }^{494}$.

487 Queensland Government Chief Procurement Office, Department of Public Works, "State Procurement Policy: better Procurement, better Outcomes" (Queensland Government, Department of Public Works, September 2010), p.9, available at https://www.energex.com.au/_data/assets/pdf_file/0007/343951/StateProcurement-Policy-2010.pdf.

${ }^{488}$ Queensland Government, Department of Housing and Public Works, "Queensland Procurement Policy" (Queensland Government, Department of Housing and Public Works, June 2013), p.9, available at https://www.cabinet.qld.gov.au/documents/2013/Jun/Procurement/Attachments/Attachment\%20\%20Queensland\%20Procurement\%20Policy\%202013.PDF.

${ }^{489}$ Under a procedure referred to in the above Queensland procurement policy as a "Selective offer" method Queensland Government, Department of Housing and Public Works, "Queensland Procurement Policy" (Queensland Government, Department of Housing and Public Works, June 2013), p.10, available at https://www.cabinet.qld.gov.au/documents/2013/Jun/Procurement/Attachments/Attachment\%20\%20Queensland\%20Procurement\%20Policy\%202013.PDF.

490 The method is referred to as the "Selective offer process" under the Queensland procurement policy Queensland Government, Department of Housing and Public Works, "Queensland Procurement Policy" (Queensland Government, Department of Housing and Public Works, June 2013), p.10, available at https://www.cabinet.qld.gov.au/documents/2013/Jun/Procurement/Attachments/Attachment\%20\%20Queensland\%20Procurement\%20Policy\%202013.PDF.

491 The procedure used was called a "Limited offer process", defined in the above Queensland procurement policy as "a procurement method where the agency invites a supplier/s of its choice to offer" - Queensland Government, Department of Housing and Public Works, "Queensland Procurement Policy" (Queensland Government, Department of Housing and Public Works, June 2013), p.10, available at https://www.cabinet.qld.gov.au/documents/2013/Jun/Procurement/Attachments/Attachment\%20$\% 20 Q u e e n s l a n d \% 20$ Procurement\%20Policy\%202013.PDF; in these cases the process took the form of an invitation to several suppliers - that is, a competitive process within our definition of restricted tender, rather than a direct award.

492 State of Queensland, "Gold Coast 2018 Commonwealth Games Post Games Report" (State of Queensland, 2019), p.20, available via https://publications.qld.gov.au/dataset/gold-coast-2018-commonwealth-gamespost-games-report.

${ }^{493}$ See for example T. Balym, and G. Stolz, "Gold Coast's $\$ 42 \mathrm{~m}$ Aquatic Centre pool slammed by top swimmers and coaches for not having a roof", Courier Mail, August 23, 2014, at

https://www.couriermail.com.au/news/queensland/gold-coasts-42m-aquatic-centre-pool-slammed-by-topswimmers-and-coaches-for-not-having-a-roof/news-story/13005dabb6434779e7098ee6b8721feb; and A. Potts, "Commonwealth Games Minister Stirling Hinchliffe rules out permanent aquatic centre roof", Gold Coast Bulletin, February 29, 2016, at https://www.goldcoastbulletin.com.au/sport/commonwealth-

games/commonwealth-games-minister-stirling-hinchliffe-rules-out-permanent-aquatic-centre-roof/newsstory/d7b7d1c8dd08fd7d8bf07c4b7095a0fc.

494 See State of Queensland, "Gold Coast 2018 Commonwealth Games Post Games Report" (State of Queensland, 2019), p.266, available via https://publications.qld.gov.au/dataset/gold-coast-2018commonwealth-games-post-games-report, for a breakdown of actual versus budgeted expense for each venue. 


\subsection{Central American and Caribbean Games, Veracruz, Mexico, 2014}

The amount of public information on infrastructure procurement for Veracruz varied considerably between projects. For the main sports infrastructure key information required by law (solicitation and award notice) was published, and still available, ${ }^{495}$ on Compranet, an e-procurement website. For the construction of the Xalapa Velodrome there is a link in Compranet and the solicitation and bid evaluation documents are still available but not the award notice. ${ }^{496}$ For the complementary works on the Xalapa Velodrome only the contract was published and available in Compranet ${ }^{497}$, possibly because this was a direct award. For the Village procurement no information was found on official websites but only media reports on, among other things, corruption allegations ${ }^{498}$ and failure to complete in time for the event. ${ }^{499}$ Information from the audit body was also found online. ${ }^{500}$

Our mapping covered most of the venue infrastructure, namely the construction contract for most sport venues (an integrated project for sport infrastructure, competition venues, and complementary works; value around 37 million USD), and the contract for building the Xalapa Velodrome (price unknown) and a separate contract for complementary Velodrome works (about 1.1 million USD). Although final prices are not all known, based on the auditing and aggregate value reported it appears that the mapped projects represented around $85 \%$ of the venue work. ${ }^{501}$ Our mapping also covered the Village.

The body responsible for the sport-related infrastructure procurement was the Secretaría Infraestructura y Obras Públicas, Dirección General de Obras Públicas, Gobierno del

495 Secretaría de Hacienda y Crédito Público, Compranet (Secretary of the Public Service, Compranet; authors' translation), source in Spanish at

https://compranet.hacienda.gob.mx/esop/toolkit/opportunity/opportunityDetail.do?opportunityId=307922\&opp List=PAST

${ }^{496}$ Secretaría de Hacienda y Crédito Público, Compranet (Secretary of Public Service, Compranet; authors' translation), source in Spanish at

https://compranet.hacienda.gob.mx/esop/toolkit/opportunity/opportunityDetail.do?opportunityId=54643\&oppL ist $=$ PAST.

497 Secretaría de Hacienda y Crédito Público, Compranet (Secretary of Public Service, Compranet; authors' translation), source in Spanish at

https://compranet.hacienda.gob.mx/esop/toolkit/opportunity/opportunityDetail.do?opportunityId=437392\&opp List=PAST.

498 "Villas de los Centroamericanos, negociazo para constructoras Carpin y Ara" (Central American Villages, a bargain for constructors Carpin and Ara; authors' translation), Periodistas Digitales, Plumas Libres México, January 21, 2014, source available in Spanish at https://plumaslibres.com.mx/2014/01/21/villas-de-loscentroamericanos-negociazo-para-constructoras-carpin-y-ara/; J. Ruiz, "Se caen a pedazos casas de Villas Arco Sur" (Villages Arco Sur fall apart; authors' translation), Marcha México, February 23, 2016, source available in Spanish at http://marcha.com.mx/resumen.php?id=75709.

499 J.H. Estrada, "Carpín despreocupado por las Villas Centroamericanas; ya está vendiendo las casas" (Carpín unconcerned about Central American Villages is already selling houses; authors' translation), Metropolitano, August 21, 2014, source available in Spanish at http://www.metropolitanoenlinea.com/?p=42698; N. Zabaleta and B. Pereyra, "Federación y estado documentan la transa" (Federation and State documenting corrupt acts; authors' translation), Proceso, March 13, 2016, source available in Spanish at https://noticias.vlex.com.mx/vid/federacion-documentan-transa-628863951; C. García, "No habrá Villa centroamericana en Veracruz" (There will be no Central American Village in Veracruz; authors' translation), Centro Urbano, August 14, 2014, source available in Spanish at https://centrourbano.com/2014/08/14/nohabra-villa-centroamericana-en-veracruz/; N. Zavaleta and R. Ochoa, "Los Juegos del Hambre... y de las deudas" (The hunger games... and the debts; authors' translation), Proceso, July 11, 2015, source available in Spanish at https://realidadalternativajp.blogspot.com/2015/07/los-juegos-del-hambre-y-de-las-deudas.html.

${ }^{500}$ Auditoría Superior de la Federación, Informe de Auditoría, Gobierno del Estado de Veracruz de Ignacio de la Llave: Programas y Fondos Federales en el Estado de Veracruz (Superior Audit Body of the Federation, Auditing Report, Government of the State of Veracruz Ignacio de la Llave: Programmes and Federal Funding in the State of Veracruz - authors' translation), source available in Spanish at https://www.asf.gob.mx/Trans/Informes/IR2014i/Documentos/Auditorias/2014_1021_a.pdf.

501 Auditoría Superior de la Federación, Informe de Auditoría, Gobierno del Estado de Veracruz de Ignacio de la Llave: Programas y Fondos Federales en el Estado de Veracruz (Superior Audit Body of the Federation, Auditing Report, Government of the State of Veracruz Ignacio de la Llave: Programmes and Federal Funding in the State of Veracruz - authors' translation), p.16, source available in Spanish at https://www.asf.gob.mx/Trans/Informes/IR2014i/Documentos/Auditorias/2014_1021_a.pdf. 
Estado de Veracruz de Ignacio de la Llave, a permanent unit within the State government of Veracruz. Funding for construction, however, came from the Federal Government so that the Act of Public Works and Related Services (Ley de Obras Públicas y Servicios Relacionados) applied to the Veracruz government.

The approach chosen, as noted above, was a single contract covering both design and build for most of the sport venues ${ }^{502}$, but also with two contracts for the Velodrome (construction and complementary works), one for rowing, one for rafting, and two for a football stadium. All venues were taken into public ownership. The Village, on the other hand, was procured using a PPP with private financing. The media reported that the land was transferred by the government to the private partner which retained its property even though the Village was not ready for the Games. ${ }^{503}$

No evidence was found in the public documents on market engagement or research, and no advance notices prior to the public solicitation were found for the mapped procurements. Nor could any public information be found of risk management for integrity or procurement risks.

The legal framework, the Act for Public Works and Related Services, ${ }^{504}$ offered three procedures: open public tender, a single-stage tendering procedure in three variations (open to Mexican nationals only, open also to countries with a trade agreement on procurement with Mexico, or open to all); restricted invitation; and direct award. For both the main venue and construction of the Velodrome open public tender was used but with access only to Mexican nationals; for the Velodrome complementary works (of quite low value) a direct award was used; and there is no information on the procedure for the Village PPP. Only three bids were submitted for the main venue project, and only one, the most expensive, was considered responsive. ${ }^{505}$ The solicitations were required to be published on Compranet ${ }^{506}$, and notices were found for both the main venue and Velodrome. Electronic submission for bids is allowed, but not mandatory, under the Law (Article 36) and the solicitation notice mentioned this as an option for tenderers.

As regards contract execution, there is a formal system for controlling execution of the works (assessment and payment) ${ }^{507}$. Contract amendments are governed by legal rules that include, but are not limited to, quantitative limitations ( $25 \%$ unless there is special approval) and reasons must be given. There was no information on amendments.

There were a number of concerns over the event. As noted the Village was not completed on time and not used; and concerns were raised over the fact that the private partners kept the land granted by the State and retained the money from sale of the accommodation despite failure to deliver on time ${ }^{508}$. With the project for the sporting

\footnotetext{
${ }^{502}$ As indicated in the solicitation and award notices, as well as the contract. The designs (preliminary draft) were part of the tender.

503 "Villas de los Centroamericanos, negociazo para constructoras Carpin y Ara" (Central American Villages, a bargain for constructors Carpin and Ara; authors' translation), Periodistas Digitales, Plumas Libres México, January 21, 2014, source available in Spanish at https://plumaslibres.com.mx/2014/01/21/villas-de-loscentroamericanos-negociazo-para-constructoras-carpin-y-ara/; J.H. Estrada, "Carpín despreocupado por las Villas Centroamericanas; ya está vendiendo las casas" (Carpín unconcerned about Central American Villages is already selling houses - authors' translation), Metropolitano, August 21, 2014, source available in Spanish at http://www. metropolitanoenlinea.com/?p=42698.

504 Ley de Obras Públicas y Servicios Relacionados con las mismas, Nueva Ley publicada en el Diario Oficial de la Federación el 4 de enero de 2000 (Act for Public Works and Related Services, New Act published in the Oficial Journal of the Federation on January 4, 2000; authors' translation).

${ }_{505}$ As indicated in the award notice from 7 November 2013.

506 Article 32 of the Act for Public Works and Related Services.

507 Chapter 2 of the Act for Public Works and Related Services.

508 J.H. Estrada, "Carpín despreocupado por las Villas Centroamericanas; ya está vendiendo las casas" (Carpín unconcerned about Central American Villages is already selling houses - authors' translation), Metropolitano, August 21, 2014, source available in Spanish at http://www.metropolitanoenlinea.com/?p=42698; "Exigen que empresas paguen las 10 hectáreas de terreno que gobierno les donó para Villas Olímpicas" (It is required that the companies pay for the 10 hectares of land that the government donated for the Olympic Villages - authors'
} 
venues, the audit bodies found payment for works not performed (for example, on the volleyball complex), cost overruns, overpricing, and poor quality work. ${ }^{509}$ (For example, the media reported ${ }^{510}$ that an auditing body (ORFIS) ${ }^{511}$ found technical deficiencies for a significant number of venues.) More generally, the auditing process and media reports found irregularities relating to the Games organising committee, such as payment for phantom workers and false invoices. ${ }^{512}$

\subsection{African Games, Brazzaville, Republic of Congo, 2015}

Brazzaville involved construction of what is now called the Kintélé Sports Complex, where most competitions were held, although some used existing facilities. This consisted of a striking 60000 -seater stadium with athletics track, 10, 000 seater sports hall (Palais des Sport), aquatics complex, tennis and volleyball courts and other facilities. As is common with major sporting infrastructure in Africa, as mentioned earlier, the infrastructure was funded by China. The media reported that it was designed by Chinese architects in cooperation with an Australian firm, following a stadium-plus-sports hall model common in China ${ }^{513}$; and that the construction contracts were awarded to three Chinese companies ${ }^{514}$.

Internet searches in French, English and Chinese found almost no procurement information other than brief mentions in the media. No solicitations or other documents generated by the procurements were found. The information available did not even reveal clearly who undertook the procurement, the national public authorities or the Chinese authorities, or the applicable regulatory framework (if any), although as the project was funded by China it seems likely that it was undertaken according to the rules laid down by China for aid-funded procurement. There is merely a brief press mention of the contracts being awarded to Chinese companies after some kind of international invitation to tender (appel d'offre $)^{515}$. It was therefore not possible to map the

translation), Periodistas Digitales, Plumas Libres, August 12, 2014, source available in Spanish at https://plumaslibres.com.mx/2014/08/12/exigen-que-empresas-paguen-las-10-hectareas-de-terreno-quegobierno-les-dono-para-villas-olimpicas/.

${ }^{509}$ N. Zabaleta and B. Pereyra, "Federación y estado documentan la transa" (Federation and State documenting the corrupt acts- authors' translation), Proceso, March 13, 2016, source available in Spanish at https://noticias.vlex.com.mx/vid/federacion-documentan-transa-628863951; Auditoría Superior de la Federación, Informe de Auditoría, Gobierno del Estado de Veracruz de Ignacio de la Llave: Programas y Fondos Federales en el Estado de Veracruz (Superior Audit Body of the Federation, Auditing Report, Government of the State of Veracruz Ignacio de la Llave: Programmes and Federal Funding in the State of Veracruz - authors' translation; source available in Spanish at https://www.asf.gob.mx/Trans/Informes/IR2014i/Documentos/Auditorias/2014_1021_a.pdf.

510 All of this information came from: N. Zabaleta and B. Pereyra, "Federación y estado documentan la transa" (Federation and State documenting the corrupt acts- authors' translation), Proceso, March 13, 2016, source available in Spanish at at https://noticias.vlex.com.mx/vid/federacion-documentan-transa-628863951h. 511 Part of the information reported by media could be found in: Orfis, Informe del Resultado de la Fiscalización Superior, Instituto Veracruzano Del Deporte, Cuenta Pública 2016, Fase de Comprobación, (Orfis, Report of Outcomes of the Superior Audit Body, Institute for Sports of Veracruz, Public Accountability 2016, Phase of checking; authors' translation), source available in Spanish at

http://www.orfis.gob.mx/informe2016/archivos/TOMO\%20I/Volumen\%206/007\%20Instituto\%20Veracruzano \%20del\%20Deporte\%20\%20\%20\%20\%20\%20.pdf.

512 N. Zabaleta and B. Pereyra, "Federación y estado documentan la transa" (Federation and State documenting the corrupt acts; authors' translation), Proceso, March 13, 2016, source available in Spanish at https://www.proceso.com.mx/433240/centroamericanos-veracruz-2014-federacion-documentan-la-transa.

513 "New stadium: Congo feels proud again", StadiumDB.com, September 4, 2015, at http://stadiumdb.com/news/2015/09/new_stadium_congo_feels_proud_again.

514 "Infrastructures sportives: Les congolais savourent le complexe sportif de la Concorde" (Sporting infrastructure: The Congolese enjoy the Concorde sports centre) (authors' translation), Alterteplusinfos, September 2, 2015, source available in French at

https://alerteplusinfos.wordpress.com/2015/09/02/infrastructures-sportives-les-congolais-savourent-lecomplexe-sportif-de-la-concorde/.

515 "Infrastructures sportives: Les congolais savourent le complexe sportif de la Concorde" (Sporting infrastructure: The Congolese enjoy the Concorde sports centre) (authors' translation), Alterteplusinfos, September 2, 2015, source available in French at

https://alerteplusinfos.wordpress.com/2015/09/02/infrastructures-sportives-les-congolais-savourent-lecomplexe-sportif-de-la-concorde/. 
procurement for this infrastructure in the same way as for other events, even to a limited degree.

The stadium is reported as having been completed a few weeks before the Games ${ }^{516}$. The media reported cost overruns of around $50 \%$, although it is not clear whether this refers to overruns from estimate to completion or award to completion ${ }^{517}$.

\subsection{African Cup of Nations, Gabon, 2017}

This 2017 African Cup of Nations (soccer) was hosted by Gabon after civil war in Libya, the planned host, disrupted construction there ${ }^{518}$. Gabon already had some facilities from co-hosting the event in 2012 and two new stadia, each with a capacity around 20000 , were built for 2017, Stade D'Oyem and Stade de Port-Gentil ${ }^{519}$. As with the complex built for Brazzaville, the stadia were funded by $\mathrm{China}^{520}$ and the contracts awarded to Chinese contractor, the Shanghai Construction Group and China State Construction Engineering Corps respectively ${ }^{521}$, as agreed in July and April $2015^{522}$.

As with Brazzaville, other than the very recent World Bank material (see below) internet searches in French, English and Chinese, including Government sources ${ }^{523}$, found no information on the infrastructure procurement other than brief fragmented information in the media (in all three languages). Again, no notices or other documents generated by the procurements were found. The information available again did not even reveal clearly who undertook the procurement, the national or Chinese authorities, or the regulatory framework. At the relevant time the Gabon Public Procurement Code provided for standard-type procurement methods and even limited use of single tenders to 15 percent of the total amount of contracts but a 2017 IMF review observed that 94 percent of contracts in the review period were based on single tenders ${ }^{524}$ (It is not clear whether the procurements in question were subjected to that national regulatory framework in view of the Chinese involvement.) A World Bank assessment published just before this article went to press also highlighted this extensive use of direct awards and seems to indicate that the stadia contracts both used this method ${ }^{525}$. That World Bank assessment

\footnotetext{
516 See https://www.emporis.com/buildings/1283264/stade-municipal-de-kintele-brazzaville-republic-of-thecongo.

517 "New stadium: Congo feels proud again", StadiumDB.com, September 4, 2015, at http://stadiumdb.com/news/2015/09/new_stadium_congo_feels_proud_again.

518 "Libya stripped of right to host 2017 Nations Cup", Reuters, August 23, 2014, at https://af.reuters.com/article/sportsNews/idAFKBNOGNOF920140823.

519 See, for example, https://www.supersport.com/football/africa-cup-of-nations/afcon-2017-venues.

520 S. Moussavou, "Gabon: Les banques chinoises s'engagent à financer les chantiers du stade d'Oyem et de 117 KM de route" (Gabon: Chinese banks commit to finance construction sites for d'Oyem stadium and $117 \mathrm{~km}$ of road; authors' translation), KOACI, December 5, 2015, source available in French at

https://www.koaci.com/gabon-banques-chinoises-sengagent-financer-chantiers-stade-doyem-117km-route93833.html.

521 "CAN 2017: Le Gabon sollicite I'experise chinoise pour la construction des stades" (CAN 2017: Gabon solicits Chinese expertise for construction of stadia; ; authors' translation), OGOOUE INFOS, July 23, 2015, source available in French at http://www.ogooueinfos.com/index.php?action=voirNews\&id=4052.

522 "CAN 2017: Le Gabon sollicite I'experise chinoise pour la construction des stades" (CAN 2017: Gabon solicits Chinese expertise for construction of stadia; authors' translation), OGOOUE INFOS, July 23, 2015, source available in French at http://www.ogooueinfos.com/index.php?action=voirNews\&id=4052. Oddly, there is indication in the media of financing being concluded in December 2015, through the Industrial Commercial Bank of China (ICBC) and Exim Bank: S. Moussavou, "Gabon: Les banques chinoises s'engagent à financer les chantiers du stade d'Oyem et de $117 \mathrm{KM}$ de route" (Gabon: Chinese banks commit to finance construction sites for d'Oyem stadium and $117 \mathrm{~km}$ of road; authors' translation), KOACI, December 5, 2015, source available in French at https://www.koaci.com/gabon-banques-chinoises-sengagent-financer-chantiers-stade-doyem$117 \mathrm{~km}$-route-93833.html.

${ }_{523}$ Notably the website of The Central Procurement Body.

524 International Monetary Fund, "IMF Country Report No.17/408: Gabon" (December 2017), Attachment I para.28, pp.45-46, available via https://www.imf.org/en/Publications/CR/Issues/2017/12/28/Gabon-FirstReview-of-the-Extended-Arrangement-under-the-Extended-Fund-Facility-Requests-for-45529.

525 World Bank, Gabon - Evaluation du Système National des Marchés Publics Suivant la Methodologie Revisee MAPS: Raport d'Evaluation (Gabon - Assessment of National Public Procurement System Based on the Revised MAPS Methodology: Assessment Report; ; authors' translation) (Washington D.C.: World Bank Group, July
} 
was also highly critical of the failure to retain records as required, even internally ${ }^{526}$, limiting the World Bank's own ability to review the relevant procurements. Mapping was therefore again impossible. It is not known whether any tendering procedure was held or which companies were eligible. In this respect there is merely an indication in the media that some call for tenders was made for Stade de Port-Gentil, for which French firms normally active in the field did not participate, with the media speculating that this may have been by choice through concern over payment or because they may not have been invited $^{527}$.

Both stadia were completed and used for the event although the media reported some delays and issues with Stade de Port-Gentil ${ }^{528}$, including with the electricity connection, rain, and failure to improve access roads. The media also reported that the final stadium price was unknown ${ }^{529}$.

\section{Conclusions}

In this article we presented key findings of our mapping of infrastructure procurement in international sporting events, mainly relating to venues and other sport-related infrastructure, to explain in context some of the main information used for IPACS' analysis of integrity risks. The mapping confirmed the assumption underlying IPACS' work that such infrastructure procurement is to a large extent a public sector activity although not exclusively so - and indicates that this activity generally does not even involve private funding where sport venues are concerned. The mapping also revealed how much the nature of the national procuring entities varies, from single bespoke entities procuring the whole sporting infrastructure to multiple and varied agencies generally established entities - often involving more than one layer of Government. Introducing four further events into our own study also highlighted an additional dimension to the complexity, namely use of (Chinese) donor funds to finance events in developing countries, which may require special attention.

In the light of the importance of information transparency both for monitoring activity and for learning lessons, another highlight from the mapping was the variation in, and limited nature of, public information, both at the time of the procurement and afterwards. In particular, there is very limited public information on planning (including risk management) and execution. In the case of the procurements financed by Chinese

2019), Vol.1, at 32 and Table 8, source available in French

via http://documents.worldbank.org/curated/en/878741562942266886/. This indicates that $97 \%$ by value of contracts for projects related to the Cup of Nations, Presidential election and externally funded projects used the direct award method.

${ }^{526}$ World Bank, Gabon - Evaluation du Système National des Marchés Publics Suivant la Methodologie Revisee MAPS: Raport d'Evaluation (Gabon - Assessment of National Public Procurement System Based on the Revised MAPS Methodology: Assessment Report; authors' translation) (Washington D.C.: World Bank Group, July 2019), Vol.1, at 40, source available in French

via http://documents.worldbank.org/curated/en/878741562942266886/. One of the contracts reviewed in Vol.3 (of the Assessment Report) concerned technical control of the sites for the Cup of Nations but there was no review of the construction contracts, possibly because of absence of information. The report notes that there is no obligation to publish the information.

${ }^{527}$ G. Mounomby, "Can-2017: Les entreprises françaises à l'écart au profit des consortiums chinois" (Can2017: French companies away to the benefit of Chinese companies; authors' translation), Gabon Review, July 22, 2015, source available in French at https://www.gabonreview.com/blog/can-2017-les-entreprisesfrancaises-a-lecart-au-profit-des-consortiums-chinois/.

528 "Construction du stade d'Oyem: le prestataire chinois parle des difficultés qu'il rencontre" (Construction of d'Oyem stadium: Chinese contractor talks about the difficulties encountered; authors' translation), Le Nouveau Gabon, October 26, 2015, source available in French at

http://www.lenouveaugabon.com/infrastructures/2610-9598-construction-du-stade-d-oyem-le-prestatairechinois-parle-des-difficultes-qu-il-rencontre; "Football/CAN 2017: Interruption des travaux du stade d'Oyem!" (Football/CAN 2017: Works discontinued at d'Oyem stadium!; authors' translation ), Gaboneco, November 9, 2016, source available in French at http://www.gaboneco.com/football-can-2017-interruption-des-travaux-dustade-d-oyem.html.

529 "Les chinois sur le stade de Port-Gentil" (The Chinese on the stadium of Port-Gentil; ; authors' translation), Gabon Tribune, July 6, 2015, source available in French at http://www.gabontribune.com/?Les-Chinois-sur-lestade-de-Port. 
donor funds, information was non-existent on all phases; it was also currently largely unavailable for all events that took place early in the study period, even when available at the time of the procurement. Use of electronic means was variable but more common in later events and its use certainly offers prospects for greater transparency in future.

As for the award procedure, for events for which significant information was available, most of the mapped venue procurements were undertaken broadly in compliance with national public procurement frameworks that reflect key elements of international standards, with open public tenders (sometimes, but not usually, involving dialogue) and supplier review mechanisms (which were invoked in a number of cases). However, there were also some significant departures from open tendering, including systematically at Budapest (using urgency as justification) and also for many procurements in New Delhi (although we did not specifically map any at the latter event because of limited information.) As observed, the main issues from the perspective of integrity risks here relate not to the adequacy of the formal framework but arise from unlawful use of exceptions or poor planning.

As outlined, these and other specific findings of the mapping have helped IPACS to construct proposals for international federations, Governments and implementing agencies, in particular regarding the need for more strategic collection of, and careful recording of, procurement data, covering all phases; enhanced pre-tender activities, including planning and market engagement; better internal and external reporting systems; and training in identification of collusion risks. Such measures can no doubt contribute towards mitigation of integrity risks - and other risks - in future events, especially so far as opportunistic corruption is concerned.

Consideration of the overall context of the mapped events, however, highlights the challenges involved in the light of literature findings on the peripheral role for procurement standards for agents in the face of endemic corruption involving the principals (politicians and senior civil servants). As we have seen, many of the mapped events were the subject of extensive or proven integrity allegations linked to the principal actors, often in spite of the regulatory frameworks. It is tempting to conclude that the only effective way to avoid integrity problems is to take more significant account of the country environment in choosing host countries but this, even if considered desirable, faces the obstacles of the reduced interest in hosting events by many "clean" countries, corruption problems in competitions to host events, and the position of the principals in the organisations allocating those events. On a positive note, however, of the mapped events held in countries with an endemic corruption problem, South Africa demonstrates that with political will it is possible largely to avoid public corruption, even in an environment in which procurement is fragmented. Further, the experience of Brazil with Rio and other events shows how integrity problems surrounding a major event can be a catalyst for change in both integrity and procurement policies that could have wider benefits for the host nations. For these situations, and for those countries where procurement corruption is more opportunistic than endemic, our mapping has identified useful concerns, information gaps and possible good practices. Applying the lessons from these findings, including by following the IPACS proposals, can both benefit the events to which they are applied and the hosts' own future procurement and help preserve the lessons from those events for future events elsewhere. 